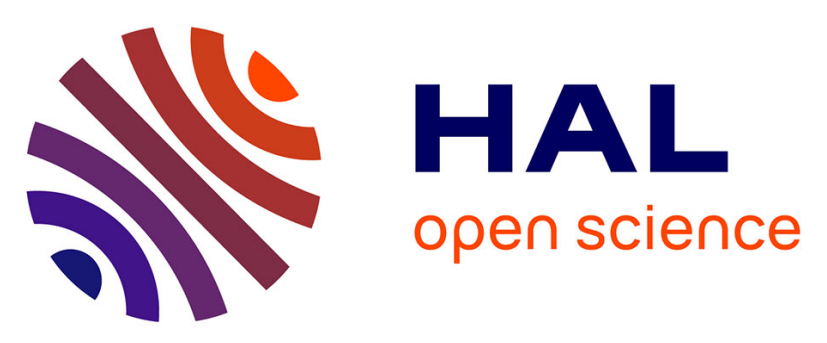

\title{
1,3-Dioxa-[3,3]-sigmatropic Oxo-Rearrangement of Substituted Allylic Carbamates: Scope and Mechanistic Studies
}

Maddalen Agirre, S. Henrion, Ivan Rivilla, José Miranda, Fernando Cossío, Bertrand Carboni, José Villalgordo, François Carreaux

\section{To cite this version:}

Maddalen Agirre, S. Henrion, Ivan Rivilla, José Miranda, Fernando Cossío, et al.. 1,3-Dioxa-[3,3]sigmatropic Oxo-Rearrangement of Substituted Allylic Carbamates: Scope and Mechanistic Studies. Journal of Organic Chemistry, 2018, 83 (24), pp.14861-14881. 10.1021/acs.joc.8b01320 . hal01954300

HAL Id: hal-01954300

https://hal-univ-rennes1.archives-ouvertes.fr/hal-01954300

Submitted on 24 Jan 2019

HAL is a multi-disciplinary open access archive for the deposit and dissemination of scientific research documents, whether they are published or not. The documents may come from teaching and research institutions in France or abroad, or from public or private research centers.
L'archive ouverte pluridisciplinaire HAL, est destinée au dépôt et à la diffusion de documents scientifiques de niveau recherche, publiés ou non, émanant des établissements d'enseignement et de recherche français ou étrangers, des laboratoires publics ou privés. 


\title{
1,3-DIOXA-[3,3]-SIGMATROPIC OXO-REARRANGEMENT OF Substituted Allylic Carbamates: Scope AND MeChanistic STUdies
}

\author{
Maddalen Agirre, ${ }^{\dagger}$ Sylvain Henrion, $₫$ Ivan Rivilla, ${ }^{\dagger}$ José I. Miranda, ${ }^{\natural}$ Fernando \\ P. Cossío, ${ }^{* \dagger}$ Bertrand Carboni, ${ }^{\ddagger}$ José M. Villalgordo, ${ }^{\S}$ and François Carreaux ${ }^{* \star}$
}

$\dagger$ Departamento de Química Orgánica I and Centro de Innovación en Química Avanzada (ORFEO-CINQA), Facultad de Química, Universidad del País Vasco/Euskal Herriko Unibertsitatea (UPV/EHU) and Donostia International Physics Center (DIPC), $\mathrm{P}^{\circ}$ Manuel Lardizabal 3, 20018 San Sebastián/Donostia, Spain. ๆ SGIker NMR Facility, Universidad del País Vasco/Euskal Herriko Unibertsitatea (UPV/ EHU), Avda. Tolosa 72, E-20018 San Sebastián/Donostia, Spain. * Univ Rennes, CNRS, ISCR (Institut des Sciences Chimiques de Rennes)-UMR 6226, 263, avenue du Général Leclerc, Campus de Beaulieu, F-35000 Rennes, France. § VillaPharma Research, Parque Tecnológico de Fuente Alamo, Ctra. El EstrechoLobosillo, Av. Azul, 30320 Murcia, Spain.

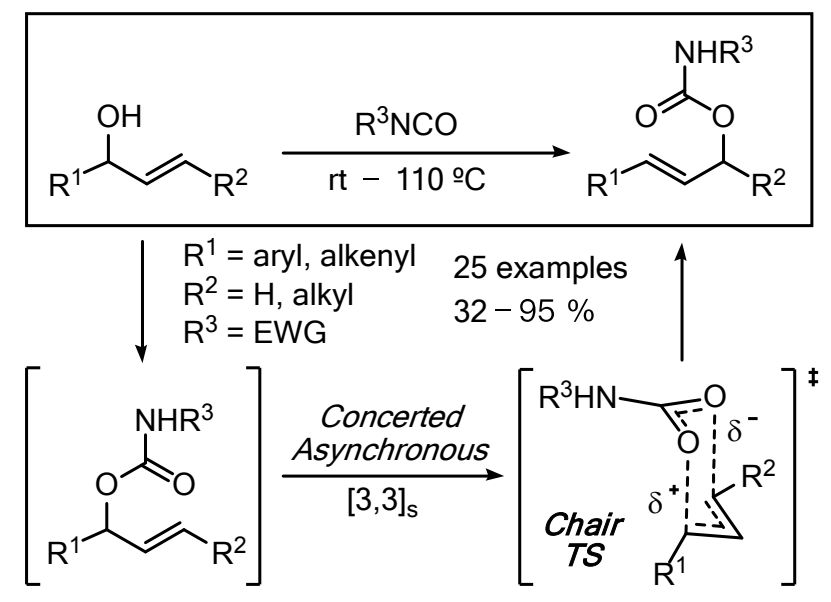

ABSTRACT: An unexpected 1,3-dioxa-[3,3]-sigmatropic rearrangement during the treatment
of aryl- and alkenyl-substituted allylic alcohols with activated isocyanates is reported. The
reorganization of bonds is highly dependent on the electron density of the aromatic ring and
the nature of isocyanate used. This metal-free tandem reaction from branched allyl alcohols
initiated by a carbamoylation reaction and followed by a sigmatropic rearrangement thus 
offers a new access to $(E)$-cinnamyl and conjugated $(E, E)$-diene carbamates such as $N$-acyl and $N$-sulfonyl derivatives. A computational study was conducted in order to rationalize this phenomenon as well as a rearrangement progress kinetic analysis was performed.

\section{INTRODUCTION}

Among the plethora of tools at the disposal of synthetic organic chemists, the $[3,3]$ sigmatropic rearrangements represent very useful methods for the regio and stereoselective formation of carbon-carbon or carbon-heteroatom bonds. ${ }^{1}$ Among the C-N bond forming reactions, the sigmatropic rearrangement of allylic trichloroacetimidates, namely the Overman rearrangement, ${ }^{2}$ occupies a place of choice as shown by the number of total synthesis involving this method. ${ }^{3}$ The decarboxylative [3,3]-rearrangement of allylic carbamates represents also a very useful strategy for the preparation of protected allylic amines from allylic alcohols with an excellent regio-and stereoselectivity. ${ }^{4,5}$ Initially reported by Holm et al. in 1970, ${ }^{6}$ the allyl cyanate/isocyanate rearrangement can be now considered as an attractive alternative method to those above-mentioned, due to the fact that the transposition occurs at or below ambient temperature, under metal-free conditions and with a complete transfer of chirality. ${ }^{7}$ The first step of this process is the formation of the transient allyl cyanate from a carbamate-type $\mathbf{B}$, under dehydration conditions, followed by a spontaneous [3,3]-sigmatropic bond reorganization to afford the corresponding allyl isocyanate $\mathbf{C}$ (Figure 1). This domino dehydration/rearrangement sequence was successfully applied on a wide variety of carbamates coming from alkyl-substituted allylic alcohols such as A. ${ }^{8}$ As a continuation of our studies on the use of this methodology for the synthesis of new reagents or original compounds, ${ }^{9}$ we envisaged the formation of branched substituted carbamates of B-type in which $\mathrm{R}$ would be an aryl group since they have never been employed to date in this kind of rearrangement. ${ }^{7 \mathrm{~b}}$ However, as preliminary result, we observed that treatment of 1-(4methoxyphenyl)prop-2-en-1-ol with trichloroacetyl isocyanate followed by a basic hydrolysis following a standard sequential process did not provide the expected branched compound (Figure 1). The only product formed was a primary carbamate $4 \mathbf{a}$ with a well-defined stereochemistry of the double bond $(E)$. In view of previous works concerning the thermal rearrangement of allylic esters, ${ }^{10,11}$ we envisioned at this stage that the formation of $4 \mathbf{a}$ could be the outcome of a rapid 1,3-dioxa-[3,3]-sigmatropic rearrangement ${ }^{12}$ from the branched trichloroacetyl carbamate intermediate before hydrolysis. 


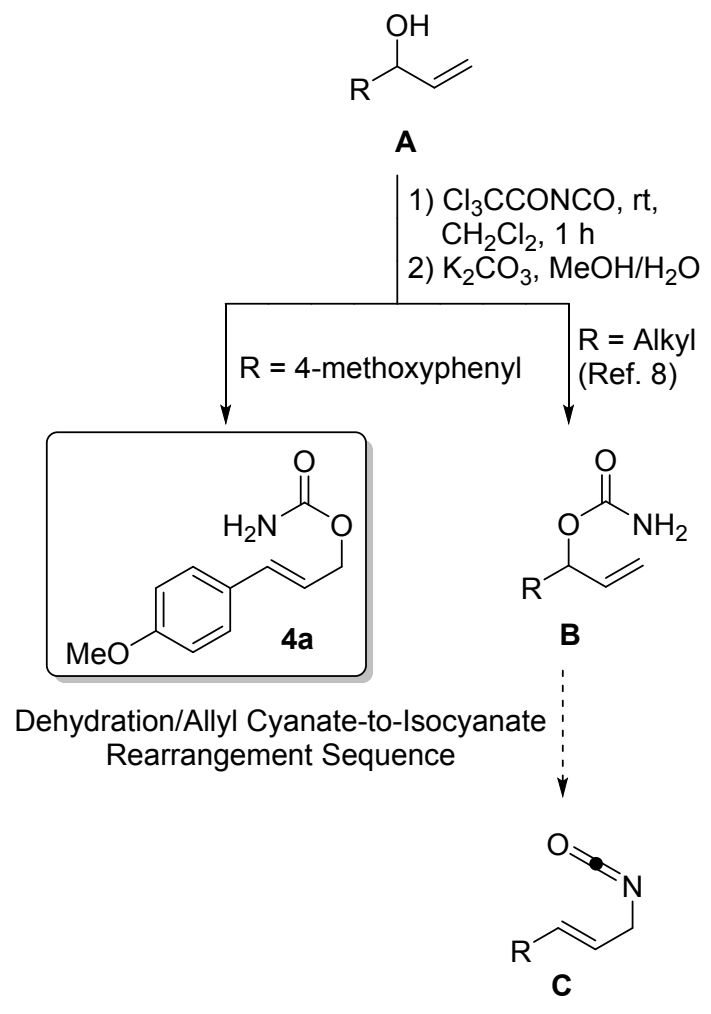

Figure 1. Observation of the uncatalyzed 1,3-dioxa-[3,3]-sigmatropic rearrangement.

Surprisingly, this rearrangement does not require any metal catalyst and takes place under neutral conditions. ${ }^{13}$ Indeed, the scarce examples described in literature require catalytic methods based on palladium (II) or mercury (II) salts. ${ }^{14}$ Taking into account the important role of molecules bearing a carbamate group as synthetic intermediates ${ }^{15}$ as well as in modern drug discovery, ${ }^{16}$ and that this one-pot process starting from 2-alken-1-ols $(\mathbf{A}, \mathrm{R}=$ aryl or alkenyl) could constitute a valuable access to linear allyl carbamates (Figure 2), ${ }^{17}$ we decided to further explore the substrate scope and limitations of this methodology in order to offer a rationalization of this phenomenon.

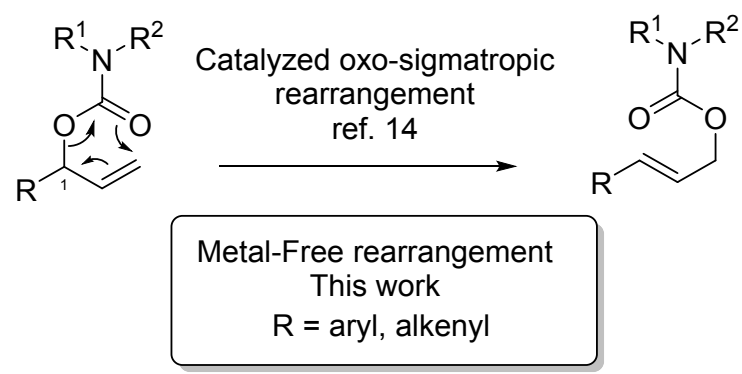

Figure 2. Proposed 1,3-dioxa-[3,3]-sigmatropic rearrangement of $O$-allyl carbamates. 
In this paper, we report the results of our study. We show that the rate of the 1,3dioxa-[3,3] sigmatropic rearrangement depends mainly on the electron density of the aromatic ring. These experimental observations have been confirmed by a kinetic study establishing that the rearrangement is of first kinetic order. The nature of the isocyanate used is also important for the transposition to occur. Activated reagents such as trichloroacetyl or $p$ toluenesulfonyl isocyanates were required. Other substrates, in which an aryl group at the allylic position (C1) was replaced by an alkenyl group, were also examined with success. In addition, a computational study of the mechanism has also been carried out in order to seed some light on the nature of this stereoselective thermal rearrangement.

\section{RESULTS AND DISCUSSION}

Experimental studies. First of all, we carefully examined the reaction of 1-(4methoxyphenyl)prop-2-en-1-ol 1a with trichloroacetyl isocyanate by monitoring the carbamoylation over time by ${ }^{1} \mathrm{H}$ NMR (Scheme 1). At room temperature, the reaction is complete after 15 minutes in favor of the formation of $\mathbf{3 a}$, product which may result of a $[3,3]$ sigmatropic rearrangement from intermediate 2a. At no moment during this NMR study was the branched carbamate $\mathbf{2 a}$ detected indicating the short-lived nature of this reaction intermediate even at lower temperature $\left(-70{ }^{\circ} \mathrm{C}\right)$. In all cases only the linear carbamate $\mathbf{3 a}$ was formed, with $(E)$-stereochemistry of the internal double bond. After evaporation of solvent, ${ }^{18}$ 3a could be isolated from the reaction medium by trituration techniques or used without further purification. Treatment of crude mixture under basic conditions in the presence of $\mathrm{K}_{2} \mathrm{CO}_{3}$ afforded the expected compound $4 \mathrm{a}$ with $73 \%$ overall yield from $1 \mathrm{a}$ and $62 \%$ from 4 methoxybenzaldehyde. It is noteworthy that this new compound 4a was also prepared from the same starting material, according to a conventional longer strategy (four steps instead of three) and a poorer overall yield (52\%). ${ }^{19}$

Scheme 1. Synthesis of 4a Using a Rearrangement/Hydrolysis Sequence. 


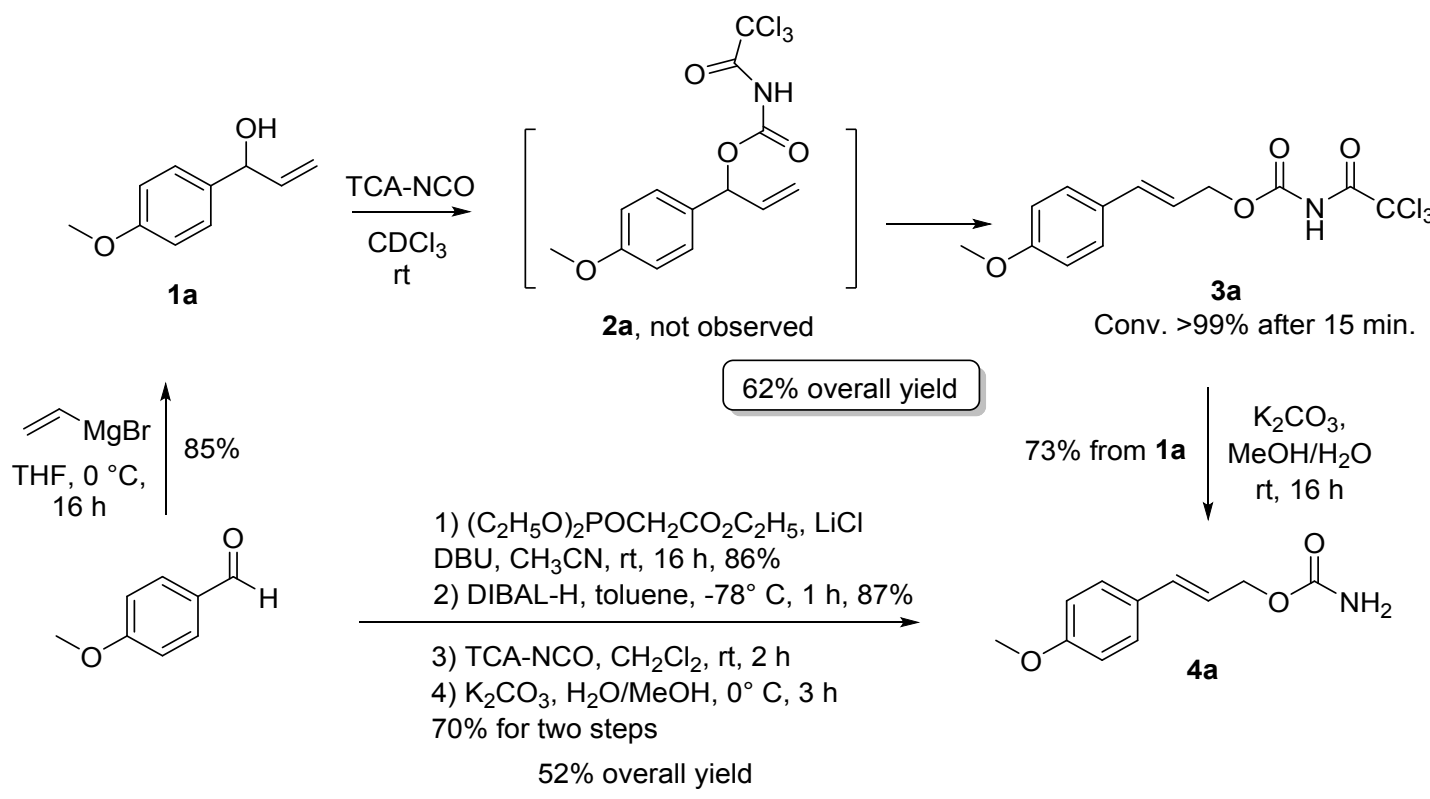

In order to determine the main factors that influence this sigmatropic rearrangement, different secondary allylic alcohols bearing both electron withdrawing and electron donating groups at para position on the aromatic ring were tested in the presence of trichloroacetyl isocyanate (TCA-NCO). As summarized in Table 1, the bond reorganization is highly dependent on the nature of the substituent. Except when the mesomeric effect is positive (+ $\mathrm{M}, \mathrm{R}=\mathrm{OMe}$, entry 1 ), heating the reaction mixture was required for all other cases (entries 2-

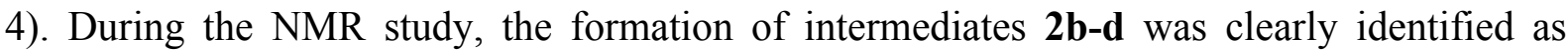
being the first step before rearrangement can occur. The results obtained confirmed that the rate of this reaction is much slower with electron-deficient aromatic rings. Indeed, conversion of $2 \mathbf{c}$ into $3 \mathbf{c}\left(\mathrm{R}=\mathrm{Cl}\right.$, - $\mathrm{I}$ and $+\mathrm{M}$ effects) was complete after $20 \mathrm{~h}$ at $90{ }^{\circ} \mathrm{C}$ (entry 3 ) while with $\mathrm{R}=\mathrm{NO}_{2}$ (-I and $-\mathrm{M}$ effects), the time of reaction was increased sixfold to reach only $50 \%$ conversion to 3d (entry 4). These results suggest a significant electron-deficient character for the allyl moiety along this sigmatropic process. After evaporation of solvent and hydrolysis under basic conditions, all linear carbamates 4 were obtained as single stereoisomer $(E)$ and with moderate to good yields.

Table 1. Synthesis of Linear Carbamates 4 from Allyl Alcohols 1 Using Trichloroacetyl Iscocyanate. 


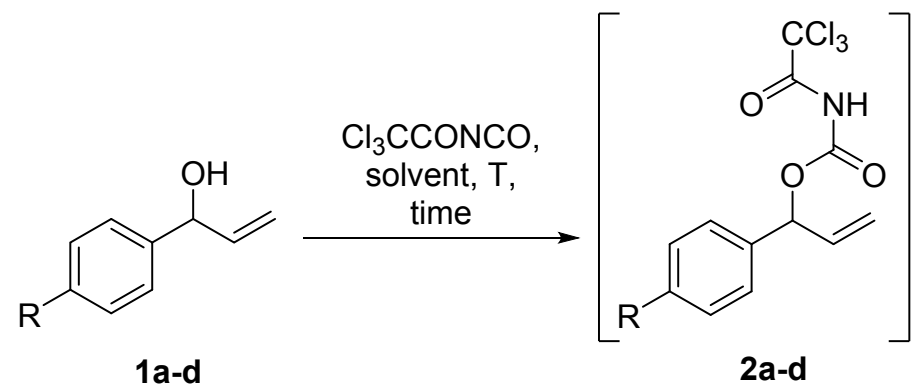

a: $\mathrm{R}=\mathrm{MeO}$

(Not Isolated)

b: $\mathrm{R}=\mathrm{H}$

c: $\mathrm{R}=\mathrm{C}$

d: $\mathrm{R}=\mathrm{NO}_{2}$<smiles>[R]c1ccc(/C=C/COC(N)=O)cc1</smiles>

$4 a-d$

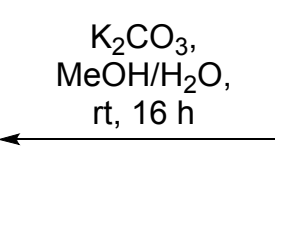

$\mathrm{R}$<smiles>[R]c1ccc(/C=C/COC(=O)NC(=O)C(Cl)(Cl)Cl)cc1</smiles>

3a-d

\begin{tabular}{cccccc}
\hline Entry & $\mathrm{R}$ & Solvent & $\mathrm{T}\left({ }^{\circ} \mathrm{C}\right)$ & Time $(\mathrm{h})^{\mathrm{a}}$ & $\begin{array}{c}\text { Product } \\
(\text { Yield, } \%)^{\mathrm{b}}\end{array}$ \\
\hline 1 & $\mathrm{MeO}$ & $\mathrm{CH}_{2} \mathrm{Cl}_{2}$ & r.t. & 0.25 & $\mathbf{4 a}, 73$ \\
2 & $\mathrm{H}$ & Toluene & 90 & 16 & $\mathbf{4 b}, 92$ \\
3 & $\mathrm{Cl}$ & Toluene & 90 & 20 & $\mathbf{4 c}, 50$ \\
4 & $\mathrm{NO}_{2}$ & Toluene & 90 & $120^{\mathrm{c}}$ & $\mathbf{4 d}, 43$ \\
\hline
\end{tabular}

${ }^{\mathrm{a}}$ Reaction was monitored by ${ }^{1} \mathrm{H}-\mathrm{NMR}$ until total consumption of starting material using a deuterated solvent. ${ }^{\mathrm{b}}$ Isolated yield of pure product. ${ }^{\mathrm{c}} 50 \%$ conversion observed.

Considering the potential importance of dienyl carbamates in the synthesis of natural products, ${ }^{20}$ the carbamoylation/rearrangement/hydrolysis sequence was also extended to other substrates such as C3-alkenyl-substituted allylic alcohols $\mathbf{5}$. The results indicated in Table 2 led to similar conclusions regarding the electronic effects that promote the rearrangement. More the aromatic ring was electron-rich, faster was the sigmatropic process. The difference of reaction rate between starting materials $\mathbf{1}$ and $\mathbf{5}$, both of them possessing the same substitution pattern on the aromatic ring can be in part explained by the generation of a conjugated diene unit acting as the driving force due to the higher stability of products $\mathbf{6}$. For instance, the rearrangement took place from $\mathbf{5 c}$ in the presence of trichloroacetyl isocyanate (Table 2, entry 3) without heating, whereas a temperature of $90{ }^{\circ} \mathrm{C}$ was required for starting alcohol 1c (Table 1, entry 3). In the case of nitro group (entry 4, Table 2), the rearranged product 6d was not observed by NMR analysis even after 7 days of reaction at $90{ }^{\circ} \mathrm{C}$, most likely due to the instability of the corresponding reaction intermediates at this temperature. In all other cases, the linear conjugated diene carbamates 7 were obtained after basic hydrolysis 
in good yields, except for $\mathrm{R}=\mathrm{OMe}$ (Table 2, entry 1), for which the purification on silica gel led to lose of product.

\section{Table 2. Carbamoylation/Rearrangement/Hydrolysis Sequence of C3-Alkenyl-} Substituted Allyl Alcohols 5.
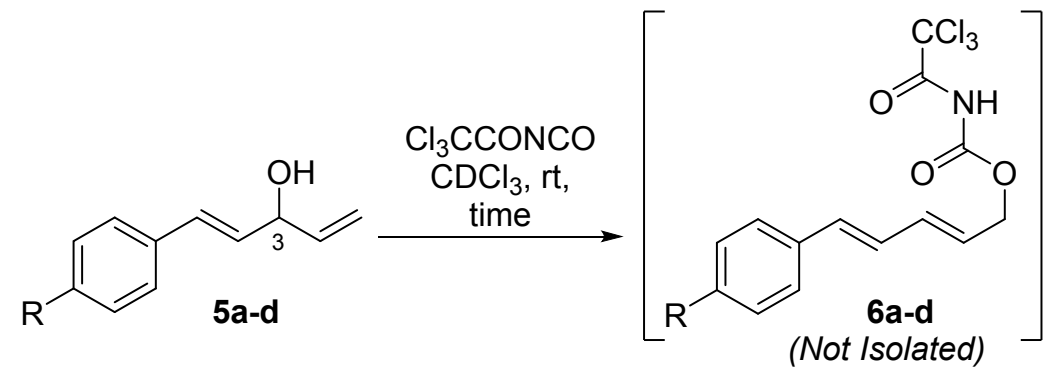
a: $\mathrm{R}=\mathrm{MeO}$
b: $\mathrm{R}=\mathrm{H}$
c: $\mathrm{R}=\mathrm{Cl}$
d: $\mathrm{R}=\mathrm{NO}_{2}$<smiles>[R]c1ccc(/C=C/C=C/COC(N)=O)cc1</smiles>

$\mathrm{K}_{2} \mathrm{CO}_{3}$,

$\mathrm{MeOH} / \mathrm{H}_{2} \mathrm{O}$ rt, $16 \mathrm{~h}$

\begin{tabular}{cccc}
\hline Entry & $\mathrm{R}$ & ${\text { Time }(\mathrm{h})^{\mathrm{a}}}^{\mathrm{a}}$ & $\begin{array}{c}\text { Product } \\
(\text { Yield, \%) }\end{array}$ \\
\hline 1 & $\mathrm{MeO}$ & 2 & $\mathbf{7 a}, 24(65)^{\mathrm{e}}$ \\
2 & $\mathrm{H}$ & 4 & $\mathbf{7 b}, 65$ \\
3 & $\mathrm{Cl}$ & 4 & $\mathbf{7 c}, 75$ \\
$4^{\mathrm{c}}$ & $\mathrm{NO}_{2}$ & $178^{\mathrm{d}}$ & - \\
\hline
\end{tabular}

a Reactions were monitored by ${ }^{1} \mathrm{H}-\mathrm{NMR}$ until total consumption of starting material. ${ }^{\mathrm{b}}$ Isolated yield of pure product. ${ }^{\mathrm{c}}$ Reaction carried out in toluene- $d 8$ at $90{ }^{\circ} \mathrm{C}$. ${ }^{\mathrm{d}}$ No formation of desired product was observed. e Determined by ${ }^{1} \mathrm{H}-\mathrm{NMR}$ using 1,3,5-trimethoxybenzene as internal reference.

In order to bring to light the utility of this new process, the synthetic interest of linear carbamates such as $\mathbf{4 a}$ was evaluated through a [3,3]-allyl cyanate rearrangement. ${ }^{21}$ Treatment of 4a with trifluoroacetic anhydride (TFAA, 1.5 equiv) in the presence of a large excess of $\mathrm{Et}_{3} \mathrm{~N}$ at $0{ }^{\circ} \mathrm{C}$ for $30 \mathrm{~min}$. led to the complete formation of isocyanate which can be quenched with various nucleophiles to afford compounds $\mathbf{8 , 9}$ and $\mathbf{1 0}$ in unoptimized yields (Scheme 2). When benzyl alcohol was used as nucleophile, a catalytic amount of $\operatorname{Ti}(\mathrm{O} t-\mathrm{Bu})_{4}$ was required. ${ }^{22}$

\section{Scheme 2. Selected In Situ Transformations of Rearranged Carbamate 4a.}




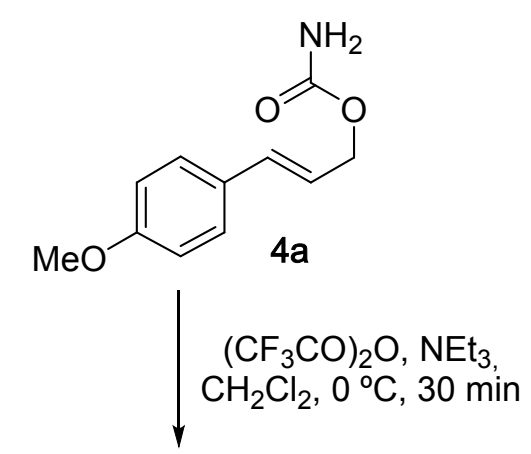<smiles>C=CC(NC(=O)N(CC)CC)c1ccc(OC)cc1</smiles><smiles>COc1ccc(/C=C/COC#N)cc1</smiles><smiles>C=CC(N=O)c1ccc(OC)cc1</smiles>

(Not Isolated)

$\mathrm{BnOH}, \mathrm{Ti}(\mathrm{Ot}-\mathrm{Bu})_{4}$, $\mathrm{CH}_{2} \mathrm{Cl}_{2}, \mathrm{rt}, 16 \mathrm{~h}$ $N$-Benzylallylamine, $\mathrm{CH}_{2} \mathrm{Cl}_{2}, \mathrm{rt}, 3 \mathrm{~h}$

\section{Carbamoylation Reaction}




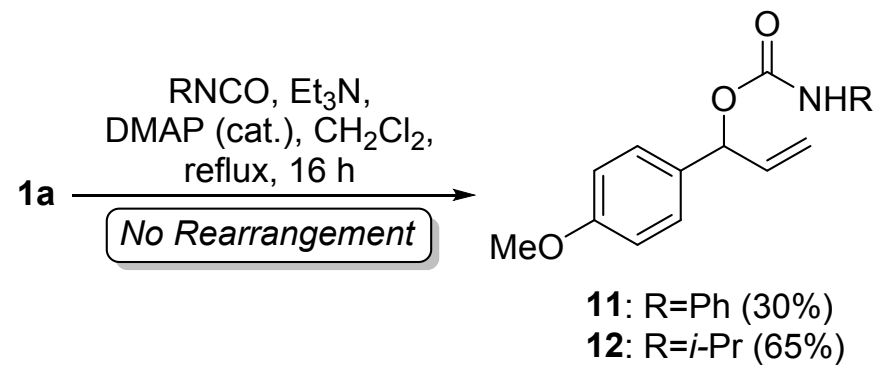

In order to validate our hypothesis that the reorganization of branched aryl allyl carbamates could be reliant on the acidity of the carbamate $\mathrm{NH}$, we tried the reaction between the allyl alcohol 1a and $p$-toluenesulfonyl isocyanate. After 15 minutes at room temperature in $\mathrm{CH}_{2} \mathrm{Cl}_{2}$, the conversion into linear $\mathrm{N}$-tosyl carbamate 14a was complete leading exclusively the $(E)$-isomer. In these conditions, the product was obtained after purification with an excellent yield (90\%) from 1a (Table 3). The one-pot reaction was extended to other aryl allyl alcohols 1 with good to high yields of purified products 14, except for 14h and 14i because of their weak stability on silica gel. For substrates with electron-poor aromatic rings $(\mathbf{1 b}, \mathbf{1 c}, \mathbf{1 d}$, 1e), heating in toluene solution was required. In all cases, the exclusive $E$-isomer formation of the internal double bond was maintained. Structure of $14 \mathrm{e}$ was determined by X-ray crystallography.

\section{Table 3. 1,3-dioxa-[3,3]-Sigmatropic Rearrangement Using p-Toluenesulfonyl Isocyanate as Reagent.}


<smiles>C=CC([Al])OC(=O)NS(=O)(=O)c1ccc(C(C)(C)C)cc1</smiles><smiles>CNC(=O)OC/C=C/c1ccc(OC)cc1</smiles><smiles>CNC(=O)NCCOCC=Cc1ccccc1</smiles><smiles>O=C(NCCOCC=Cc1ccc(Cl)cc1)Nc1ccccc1</smiles>

14a, $\mathrm{CH}_{2} \mathrm{Cl}_{2}$, rt, 15 min., $90 \%$

14b, Toluene, $90^{\circ} \mathrm{C}$, $6 \mathrm{~h}, 95 \%$

14c, Toluene, $90^{\circ} \mathrm{C}$, $20 \mathrm{~h}, 70 \%$<smiles>O=C(N[O+])NCCOCC=Cc1ccc([N+](=O)[O-])cc1</smiles>

14d, Toluene, $90^{\circ} \mathrm{C}$, 4 days, $40 \%$<smiles>CCNC(=O)OC/C=C/c1ccc(C)cc1</smiles>

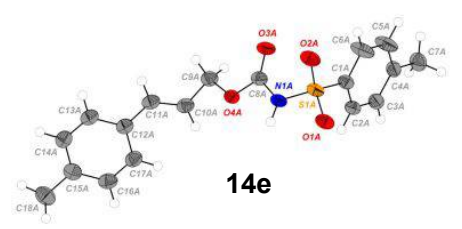

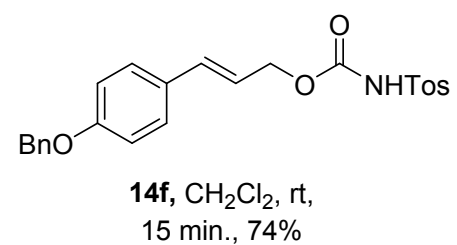

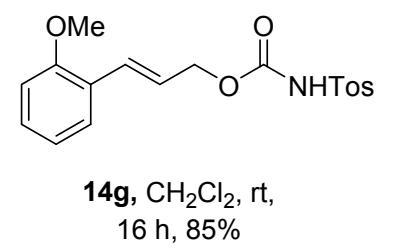

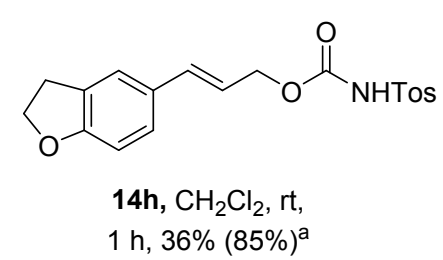<smiles>CCCCCCNC(=O)OC/C=C/c1ccc(OC)c(OC)c1</smiles><smiles>CCNC(=O)OC/C=C/c1ccc(OC)c(OCc2ccccc2)c1</smiles><smiles>[CH2+]NC(=O)OC/C=C/c1ccc2c(c1)OCO2</smiles>

14i, $\mathrm{CH}_{2} \mathrm{Cl}_{2}$, rt, $45 \mathrm{~min}$., $32 \%(80 \%)^{\mathrm{a}}$

$14 \mathrm{j}, \mathrm{CH}_{2} \mathrm{Cl}_{2}$, rt, $45 \mathrm{~min} ., 54 \%$

14k, $\mathrm{CH}_{2} \mathrm{Cl}_{2}, \mathrm{rt}$, $3 \mathrm{~h}, 84 \%$

${ }^{\text {a }}$ Determined by ${ }^{1} \mathrm{H}-\mathrm{NMR}$ using 1,3,5-trimethoxybenzene as internal reference.

Benzoyl isocyanate was also successfully employed to yield the rearranged product $\mathbf{1 5}$ from 1a (Scheme 4). After 30 minutes in $\mathrm{CDCl}_{3}$, the starting material was completely consumed and the primary carbamate 15 was obtained in $63 \%$ yield after purification.

\section{Scheme 4. Carbamoylation/Rearrangement Sequence Using Benzoyl Isocyanate.}<smiles>COc1ccc(/C=C/COC(=O)NC(=O)c2ccccc2)cc1</smiles>

$15(63 \%)$

In the same way, the one-pot process using tosyl isocyanate reagent was carried out successfully from $\mathrm{C} 3$-alkenyl-substituted allyl alcohols $\mathbf{5}$ to afford the corresponding $(E, E)$ - 
conjugated linear carbamates 16 (Table 4). Nevertheless, compound 16d $\left(\mathrm{R}=\mathrm{NO}_{2}\right.$, Table 4, entry 4) was obtained in moderate yield after separation of the unreacted starting material.

Table 4. Carbamoylation/Rearrangement Sequence Using Tosyl Isocyanate From C3Alkenyl-Substituted Allyl Alcohols 5.

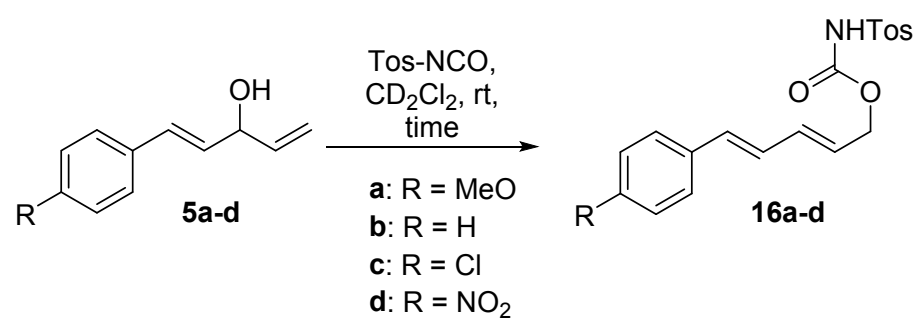

\begin{tabular}{cccc}
\hline Entry & $\mathrm{R}$ & ${\text { Time }(\mathrm{h})^{\mathrm{a}}}^{\text {Product }}$ & $\begin{array}{c}\text { PYeld, } \%)^{\mathrm{b}} \\
(\text { Yiel }\end{array}$ \\
\hline 1 & $\mathrm{MeO}$ & 0.5 & $\mathbf{1 6 a}, 25(85)^{\mathrm{e}}$ \\
2 & $\mathrm{H}$ & 4 & $\mathbf{1 6 b}, 75$ \\
3 & $\mathrm{Cl}$ & 4 & $\mathbf{1 6 c}, 68$ \\
$4^{\mathrm{c}}$ & $\mathrm{NO}_{2}$ & $120^{\mathrm{d}}$ & $\mathbf{1 6 d}, 36$ \\
\hline a Reactions $^{\mathrm{d}}$ were monitored & by ${ }^{1} \mathrm{H}-\mathrm{NMR}$ until total \\
consumption of starting material. ${ }^{\mathrm{b}}$ Isolated yield of pure \\
product. ${ }^{\mathrm{c}}$ Reaction carried out in toluene- $d 8$ at $90{ }^{\circ} \mathrm{C}$. ${ }^{\mathrm{d}} 50$ \\
\% conversion was observed. ${ }^{\mathrm{e}}$ Determined by ${ }^{1} \mathrm{H}-\mathrm{NMR}$ \\
using 1,3,5-trimethoxybenzene as internal reference.
\end{tabular}

In order to test whether the carbamoylation reaction could be followed by a sequential double sigmatropic oxo-rearrangement in a one-pot process, 1-aryl-2,4-butadien-1-ols 17 as a mixture of stereoisomers were prepared from hexanedial according to a described procedure (Scheme 5). ${ }^{25}$ Treatment of $\mathbf{1 7}$ with tosyl and benzoyl isocyanates led to the formation of the corresponding rearranged products $18 \mathbf{a b}, \mathbf{1 8 b a}$ and $18 \mathrm{bb}$ respectively. The reactions took place at room temperature with a complete conversion after $2 \mathrm{~h}$ in $\mathrm{CH}_{2} \mathrm{Cl}_{2}$, but unfortunately the purification of these compounds is difficult due to their instability on silica gel (see Experimental Section). It should be noted, however, that even in the presence of a deactivating group on the aromatic ring, these substrates are prone to undergo this consecutive double rearrangement under mild conditions, as demonstrated with alcohol $\mathbf{1 7 b}$.

Scheme 5. Consecutive [3,3]-Sigmatropic Rearrangements from Starting Alcohols 17. 


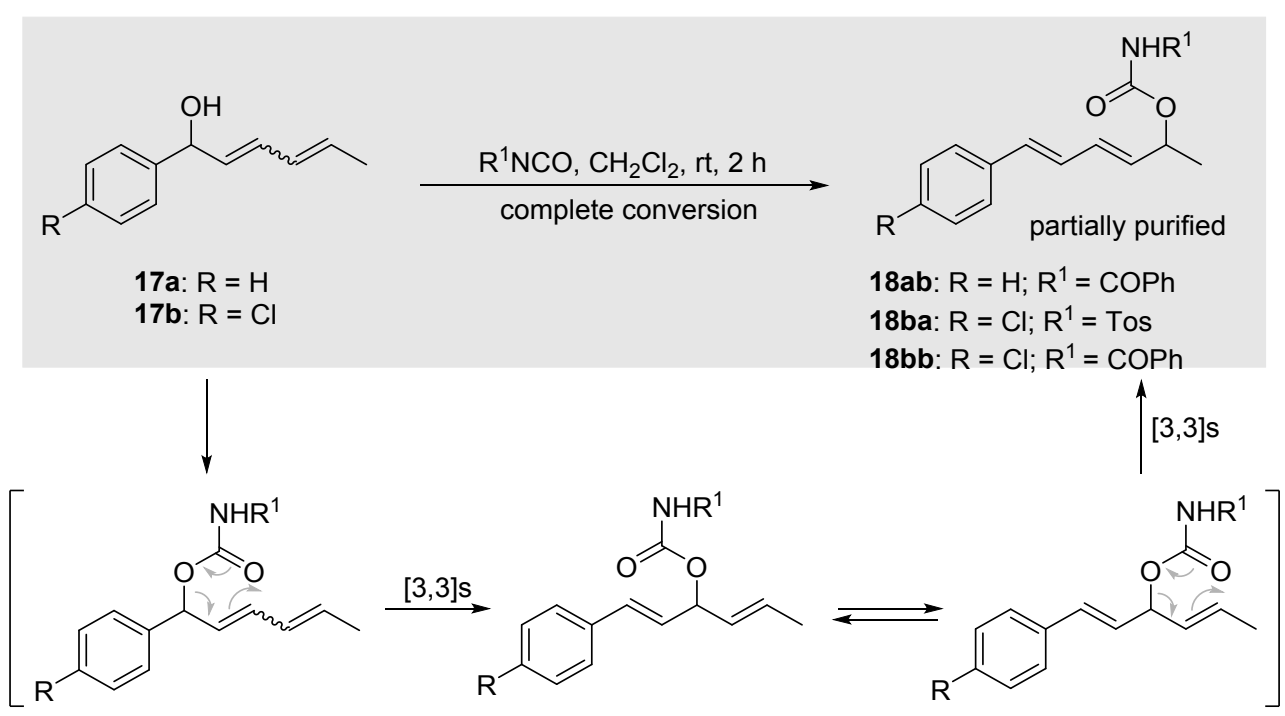

Finally, we studied the stereoselectivity of the rearrangement in terms of the transfer of chirality when a chiral allyl alcohol is used as starting reactant. To this end, we analyzed the behavior of racemic $(E)$-1-phenylbut-2-en-1-ol 20 and its $(S)$-enantiomer (Figure 3). ${ }^{26}$ This latter starting alcohol was separated from a racemic mixture by HPLC using a chiral stationary phase (see the Experimental Section). After this chromatographic separation, $(S)$-20 was obtained with an enantiomeric excess of 98\%. Both racemic and $(S)$-20 were transformed into carbamates 21 (not isolated, see Figure 3) by reaction with (R)-[1-(4-fluorophenyl)ethyl]isocyanate $(R)-19$ in the presence of triethylamine. After two days of reaction at $110{ }^{\circ} \mathrm{C}$ in toluene the corresponding rearranged products 22 was obtained. The HPLC profile of the diastereomeric mixture of $(S, R)+(R, R)$ carbamates 22 showed two well-defined peaks compatible, within the experimental error, with that would be expected for the reaction product stemming from racemic $\mathbf{2 0}$. In the case of the product formed using $(S)$-20 as reactant, formation of $(S, R)$-22 was observed with $95 \%$ diastereomeric excess, according to the HPLC profile. These results, show that, within the experimental error, most of -if not all- the observed rearrangement takes place via a symmetry allowed concerted supra-supra mechanism, with virtually complete 1,3-transfer of the chiral information contained in the starting alcohol, together with retention of configuration of the double bond. The mechanistic aspects derived from this observation shall be discussed in the following section. 


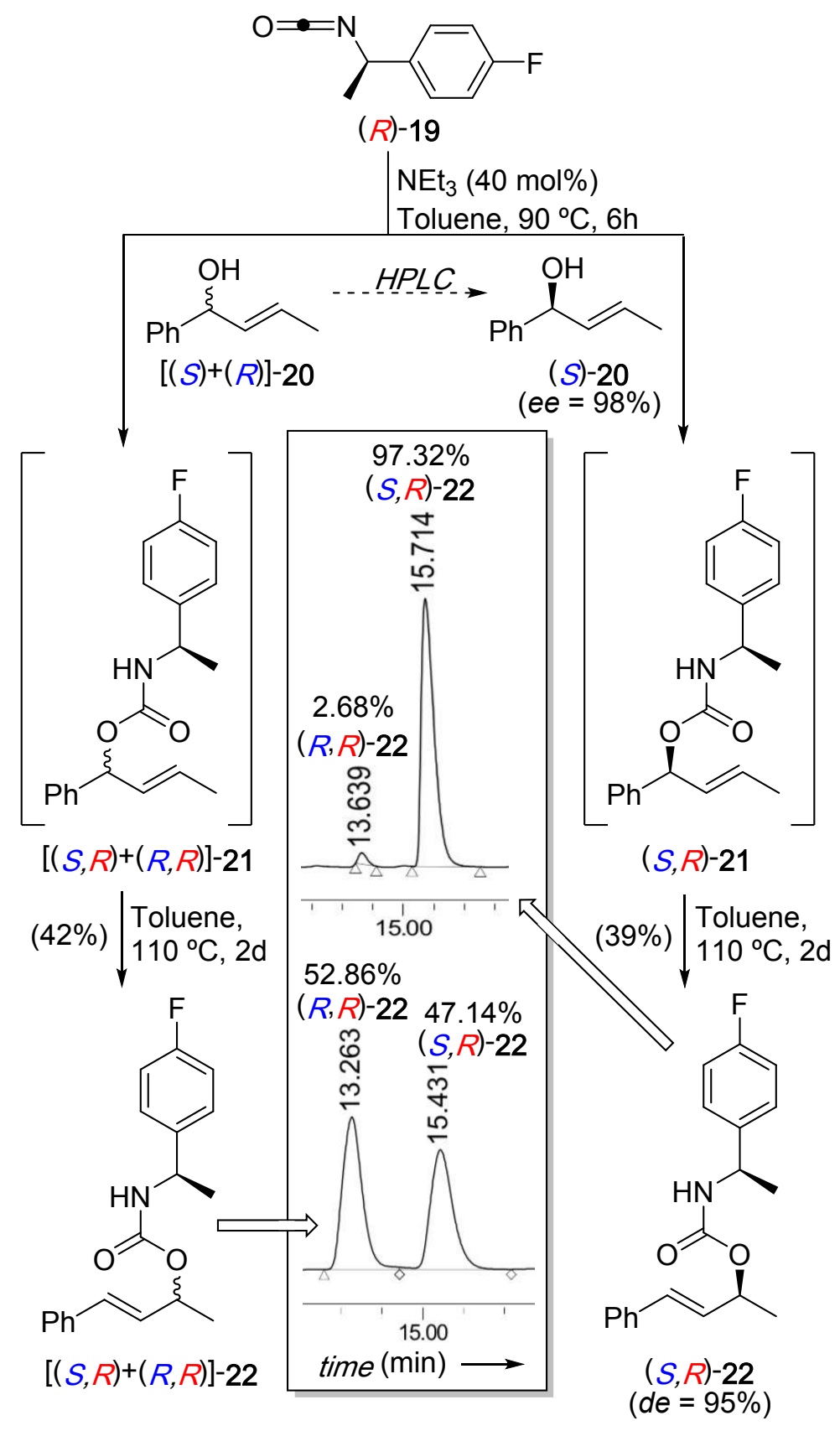

Figure 3. Assessment of the chirality transfer in the reaction between isocyanate $(R)-\mathbf{1 9}$ and alcohol 20. The HPLC chromatograms are also shown.

Mechanistic studies. Conversion of alcohols $\mathbf{1 b}, \mathbf{c}(\mathrm{R}=\mathrm{H}, \mathrm{Cl}$, respectively) into the rearranged products $\mathbf{1 4 b}, \mathbf{c}$ in the presence of $p$-toluenesulfonyl isocyanate was monitored by ${ }^{1} \mathrm{H}-\mathrm{NMR}$ in deuterated toluene at $90{ }^{\circ} \mathrm{C}$. A selected ensemble of spectra recorded at different reaction times is gathered in Figure 4. These data indicate that alcohol 1c is immediately converted into carbamate 13c, as it can be appreciated by comparison of both spectra. This intermediate 
carbamate evolves towards the rearranged product $14 \mathbf{c}$ with no detectable intermediate species. Using these NMR data and applying first-order kinetics in eq 1

$\ln [13 c]_{t}-\ln [13 c]_{0}=-k_{o b s} t$

we obtained $k_{o b s}=1.08( \pm 0.04) \times 10^{-4} \mathrm{~s}^{-1}$. A similar study for alcohol $\mathbf{1 b}(\mathrm{R}=\mathrm{H})$ led to a measured kinetic constant of $k_{o b s}=1.62( \pm 0.06) \times 10^{-4} \mathrm{~s}^{-1}$ (see the Supporting Information). These results were confirmed in a combined experiment using a 1:1 mixture of $\mathbf{1 b}$ and $\mathbf{1 c}$, to which a $50 \%$ of $p$-toluenesulfonyl isocyanate was added. After $5 \mathrm{~min}$. of reaction at room temperature, the ${ }^{1} \mathrm{H}-\mathrm{NMR}$ analysis revealed that ca. $50 \%$ of both alcohols remained unreacted, whereas carbamates $13 \mathrm{~b}$ and $13 \mathrm{c}$ were observed in a 1.0:1.2 ratio. After $6 \mathrm{~h}$ of reaction at $90{ }^{\circ} \mathrm{C}$, a complete $\mathbf{1 3 b} \rightarrow \mathbf{1 4 b}(\mathrm{R}=\mathrm{H})$ conversion was observed, whereas for the $\mathbf{1 3 c} \rightarrow \mathbf{1 4 c}(\mathrm{R}=\mathrm{Cl})$ rearrangement the conversion was of ca. $40 \%$. These results showed that the fast formation of carbamates 13 from alcohols $\mathbf{1}$ is not selective and that the subsequent dioxa-[3,3]sigmatropic rearrangements occur through a kinetically independent process, not related to the formation of the starting carbamate. In the case of alcohol $1 \mathbf{a}(\mathrm{R}=\mathrm{OMe})$ the reaction was too fast to obtain a reliable first-order kinetic under the same experimental conditions used for $\mathbf{1 b}$ and 1c. However, we could measure the first-order reaction rate until $15 \mathrm{~min}$ of reaction at room temperature and obtained $k_{\text {obs }}=1.63( \pm 0.05) \times 10^{-3} \mathrm{~s}^{-1}$, one order of magnitude faster than in the preceding cases. Similar experiments with $\mathbf{1 d}\left(\mathrm{R}=\mathrm{NO}_{2}\right)$ were not possible because the reaction was too slow. We also examined the efficiency of the reaction in the presence of polar solvents. When alcohol $\mathbf{1 b}$ and tosyl isocyanate were allowed to react in DMSO or DMF no reaction was observed, whereas in acetonitrile only $35 \%$ conversion was observed after three days of reaction at $90{ }^{\circ} \mathrm{C}$. These results are in agreement with those reported in Table 3 (vide supra). We concluded from these data that electron withdrawing groups at the aryl moiety of the starting alcohols result in lower reactivity. On the contrary, electron releasing groups such as methoxy accelerate the sigmatropic rearrangement. This conclusion is compatible with an electron deficient character of the allyl moiety at the corresponding transition state, an aspect (among others) that was analyzed by DFT calculations. 


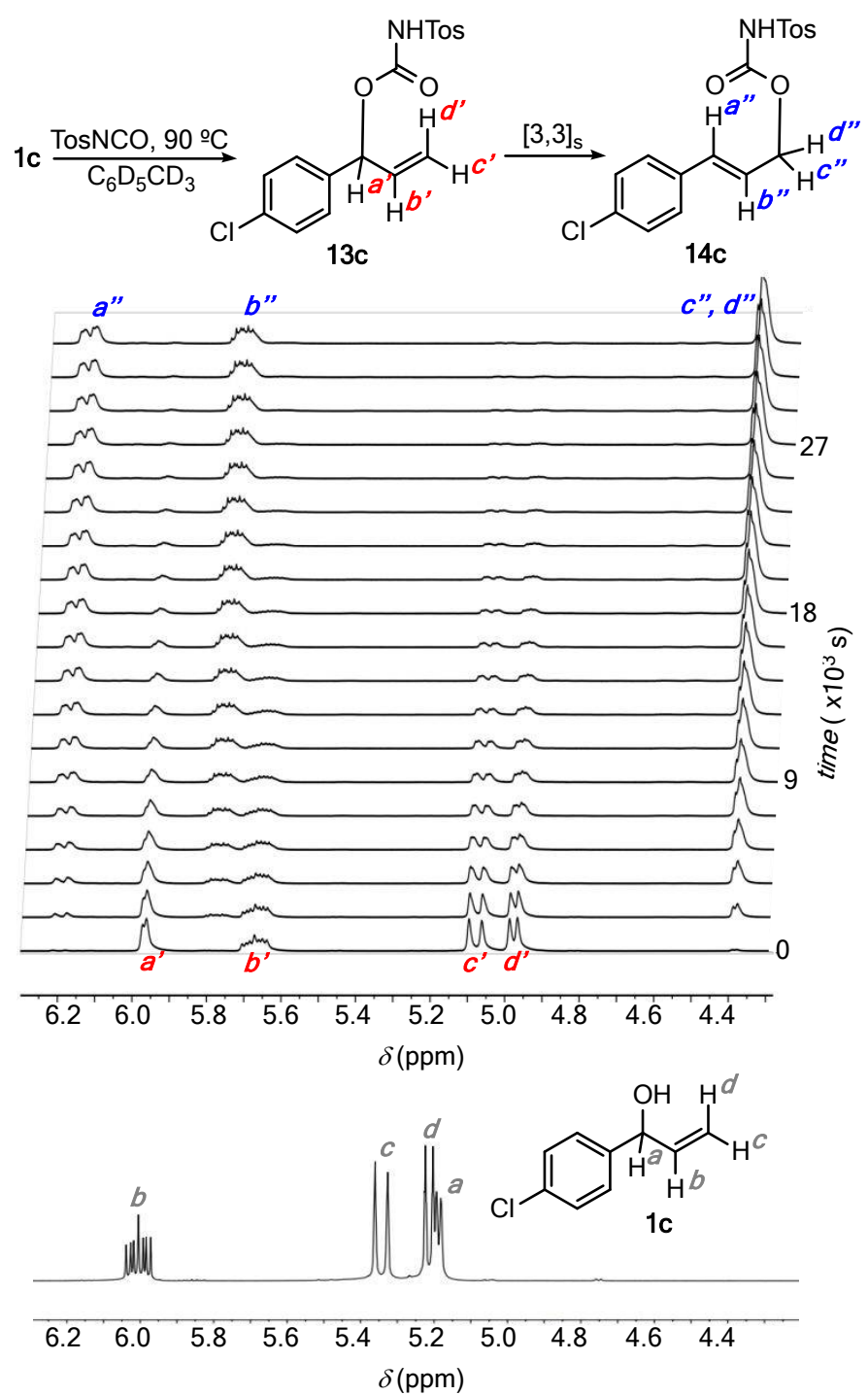

Figure 4. ${ }^{1} \mathrm{H}-\mathrm{NMR}$ plots $(500 \mathrm{MHz})$ corresponding to the reaction of 1-(4-chlorophenyl)prop2-en-1-ol 1c with of $N$-tosyl isocyanate at $90{ }^{\circ} \mathrm{C}$ to yield rearranged carbamate $14 \mathbf{c}$ via intermediate 13c. The succesive spectra, recorded at different reaction times, show the evolution of the allylic hydrogens of both carbamates. The spectrum of the allylic region of $\mathbf{1 c}$ is also shown.

Since the ${ }^{1} \mathrm{H}-\mathrm{NMR}$ showed that the formation of 1-arylallyl tosylcarbamates $\mathbf{1 3 b}$,c from alcohols 1b,c was not kinetically relevant, we carried out DFT calculations on these transformations. These calculations were performed at the B3LYP-D3(PCM)/6$311 \mathrm{G}++\mathrm{G}(\mathrm{d}, \mathrm{p})$ level of theory. Toluene was used as solvent and the Gibbs energies were calculated at $90{ }^{\circ} \mathrm{C}(363.15 \mathrm{~K})$.

Previous work on the rearrangement of allyl esters ${ }^{10 a, b}$ suggested that both $[3,3]$ and $[1,3]$ mechanisms could occur (Scheme 6). In addition, Birney, ${ }^{11,27}$ Duncan $^{28}$ and respective co-workers have indicated that in esters and acetimidates both pericyclic and pseudopericyclic mechanisms can compete. In order to elucidate the preference for the [1.3] or [3,3] topologies 
associated with these 1,3-dioxa-sigmatropic rearrangements, we studied computationally the degenerate rearrangement of allyl tosylcarbamate $\mathbf{2 3}$ via [1,3] or [3,3] sigmatropic shifts. In turn, within the $[3,3]$ reaction path, we considered chair and boat geometries for the corresponding saddle points (Scheme 6) as well as the possible occurrence of pseudopericyclic mechanisms.

Scheme 6. Possible [3,3] and [1,3] Mechanisms for the 1,3-Dioxa Rearrangement of Allyl Tosylcarbamate 23.

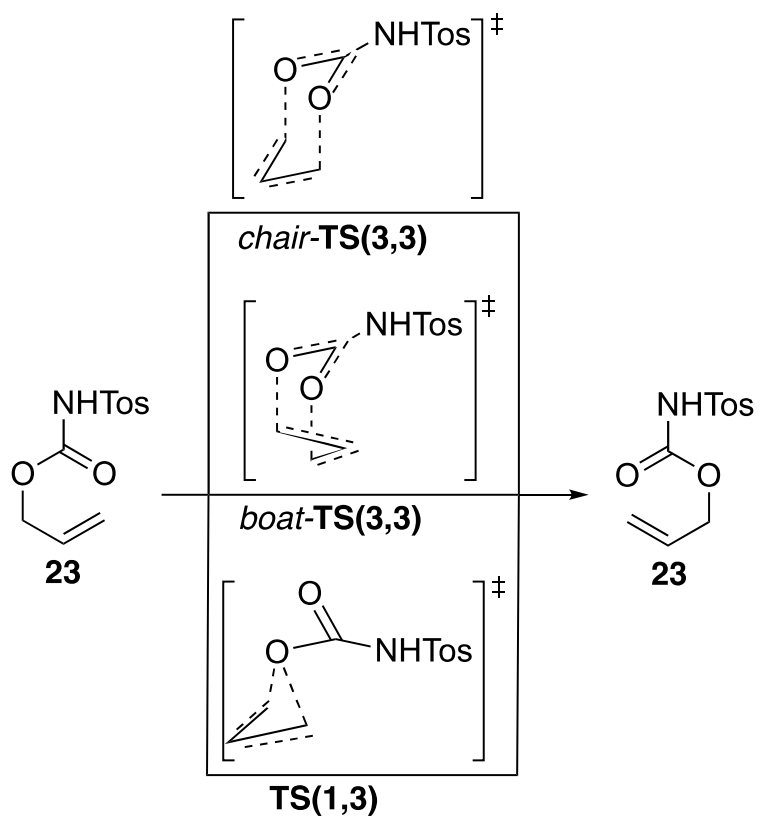

The chief geometric and energetic features of transition structures chair-TS(3,3), boat$\operatorname{TS}(3,3)$ and TS(1,3) are gathered in Figure 5. Our calculations indicate that the dioxa-[3,3]sigmatropic mechanism is clearly preferred with respect to the [1,3] rearrangement involving only one of the oxygen atoms of the carboxylate moiety. Within the $[3,3]$ mechanism, the chair geometry of the corresponding transition state is $4.6 \mathrm{kcal} / \mathrm{mol}$ less energetic than that associated with the boat analogue. These results are in agreement with the empirical observations reported by Lewis and Hill, ${ }^{10}$ who established that the $[1,3]$ mechanism is substantially more energetic than the [3,3] reaction path. On the other hand, the dihedral angles calculated for the three transition structures shown in Figure 5 indicate $\pi-\pi$ interactions between both reactants, with dihedral angles $\omega$ of $85-110$ deg. Since the participation of the lone pairs (orbitally disconnected to the $\mathrm{C}=\mathrm{O} \pi$-orbitals) of one or two oxygen atoms should lead to $\omega$ values close to $180 \mathrm{deg}$. (vide infra), we concluded that both 
$[1,3]$ and $[3,3]$ geometries shown in Figure 5 correspond to pericyclic and not to pseudopericyclic processes. In addition, these 1,3-dioxa-[3,3]-sigmatropic rearrangements take place via chair geometries and symmetry allowed ${ }^{29}$ supra-supra topologies.
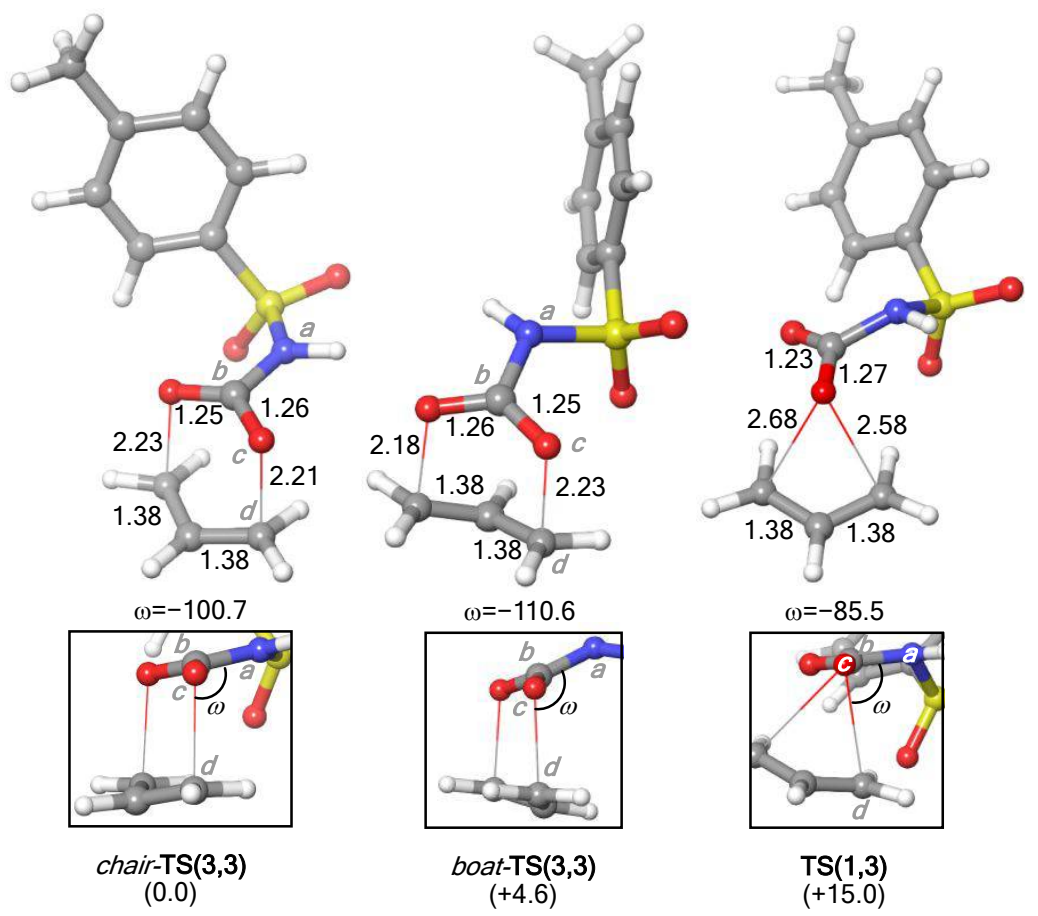

Figure 5. Optimized structures (B3LYP-D3(PCM=toluene)/6-311++G(d,p) level of theory) of transition structures chair-TS(3,3), boat-TS(3,3) and TS(1,3) depicted in Scheme 6. Bond distances are in $\AA$. Dihedral angle $\omega$ (in deg.) is defined by the $a-b-c-d$ atoms. Numbers in parenthesis are the relative energies, in $\mathrm{kcal} / \mathrm{mol}$.

We also performed isotope labeling NMR experiments in order to verify the previously discussed computational results. These experiments were carried out by using a mixture of $11.1 \% \quad \mathrm{H}_{2}{ }^{17} \mathrm{O}, \quad 29.7 \% \quad \mathrm{H}_{2}{ }^{18} \mathrm{O} \quad$ and $59.2 \% \quad \mathrm{H}_{2}{ }^{16} \mathrm{O}$. Conversion of (trichloromethyl)benzene $\mathbf{2 4}$ into doubly labeled benzoic acid $\mathbf{2 5}$ under microwave irradiation ${ }^{30}$ permitted two synthetic routes (Figure 6A). In the first one, we prepared diester 26 following a described procedure. ${ }^{31}$ The ${ }^{17} \mathrm{O}-\mathrm{NMR}$ spectrum is shown in Figure 6B. In this spectrum two well separated signals at 340 and $136 \mathrm{ppm}$ can be observed, associated with the $\mathrm{sp}^{2}$ and $\mathrm{sp}^{3}$-hybrydized ${ }^{17} \mathrm{O}$ nuclei, respectively. This process permitted us to calibrate the performance of ${ }^{17} \mathrm{O}-\mathrm{NMR}$ to distinguish the starting and final resonances associated with the $\left[{ }^{17} \mathrm{O}_{1}\right] \mathbf{1 3 b} \rightarrow\left[{ }^{17} \mathrm{O}_{1}\right] 14 \mathbf{b}$ transformation. 
A

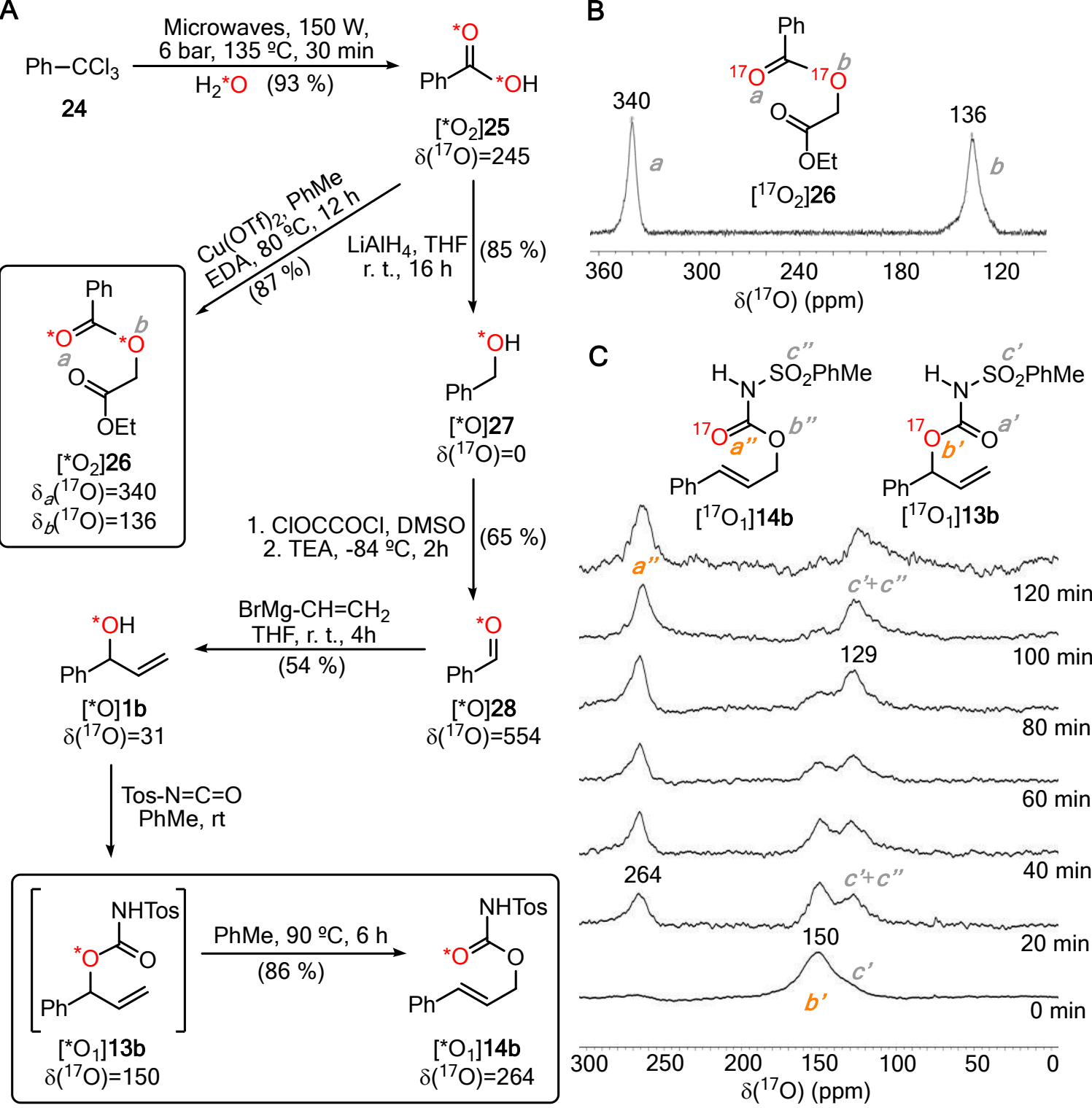

Figure 6. (A) Synthesis of labelled allyl tosylcarbamates $\left[{ }^{*} \mathrm{O}_{1}\right] \mathbf{1 3 b}$ and $\left[{ }^{*} \mathrm{O}_{1}\right] \mathbf{1 4 b}$, and diester $\left[{ }^{*} \mathrm{O}_{2}\right]$ 26. The $\left[{ }^{17} \mathrm{O}\right]$-labeled compounds were synthesized from a mixture of $11.1 \% \mathrm{H}_{2}{ }^{17} \mathrm{O}$, together with $29.7 \% \mathrm{H}_{2}{ }^{18} \mathrm{O}$ and $59.2 \% \mathrm{H}_{2}{ }^{16} \mathrm{O}$. The $\delta\left({ }^{17} \mathrm{O}\right)$ chemical shifts of the $\left[{ }^{17} \mathrm{O}\right]$-labelled compounds are given in ppm. (B) ${ }^{17} \mathrm{O}-\mathrm{NMR}$ spectrum of diester $\left[{ }^{17} \mathrm{O}_{2}\right] \mathbf{2 6}$, in which the $\mathrm{sp}^{2}$ and $\mathrm{sp}^{3}$-hybridized oxygen atoms can be distinguished. (C) ${ }^{17} \mathrm{O}-\mathrm{NMR}$ spectra of the $\left[{ }^{17} \mathrm{O}_{1}\right] \mathbf{1 3 b}$ $\rightarrow\left[{ }^{17} \mathrm{O}_{1}\right] \mathbf{1 4 b}$ transformation recorded in $\mathrm{d}^{8}-\mathrm{PhMe}$ at different reaction times. The signals of sulfone oxygen atoms ( $c$ ' and $c^{\prime \prime}$, natural abundances) are also given.

The second synthetic route of labeling experiments consisted of the conversion of labeled benzoic acid 25 into allyl alcohol 1b via a sequence of reduction, oxidation and addition reactions involving O-labeled benzyl alcohol 27 and benzaldehyde 28, whose diagnostic $\delta\left({ }^{17} \mathrm{O}\right)$ chemical shifts are gathered in Figure 6A (see the Supporting Information for further details). Reaction of labeled $\mathbf{1 b}$ with tosyl isocyanate led almost immediately (vide 
supra) to labeled 13b. The ${ }^{17} \mathrm{O}-\mathrm{NMR}$ spectrum of labeled $\left[{ }^{17} \mathrm{O}_{1}\right] \mathbf{1 3 b}$ showed a very broad signal at $150 \mathrm{ppm}$, partially superimposed to the signal associated with the sulfone moiety (natural abundance, see the Supporting Information for further details). Heating of $\left[{ }^{17} \mathrm{O}_{1}\right] \mathbf{1 3 b}$ led us to observe a new signal at $264 \mathrm{ppm}$ (Figure 6C), which was interpreted as associated with the sp ${ }^{2}$-hybrydized ${ }^{17} \mathrm{O}$ nucleus of $\left[{ }^{17} \mathrm{O}_{1}\right] \mathbf{1 4} \mathbf{b}$ on the basis of the related signal of $\left[{ }^{17} \mathrm{O}_{2}\right] \mathbf{2 6}$ shown in Figure 6B. The emergent signal of $\left[{ }^{17} \mathrm{O}_{1}\right] \mathbf{1 4 b}$ was coincident with the decrease of the broad signal of $\left[{ }^{17} \mathrm{O}_{1}\right] \mathbf{1 3 b}$, the broad signals of the $\mathrm{SO}_{2}$ groups of both tosyl carbamates being of similar chemical shift. ${ }^{32}$ These results, together with the above described calculations and experiments involving chiral species, led us to the conclusion that, as suggested by Lewis and Hill, ${ }^{10}$ the conversion of carbamates $\mathbf{1 3}$ into their regioisomers $\mathbf{1 4}$ takes place via concerted pericyclic 1,3-dioxa-[3,3]-sigmatropic rearrangements.

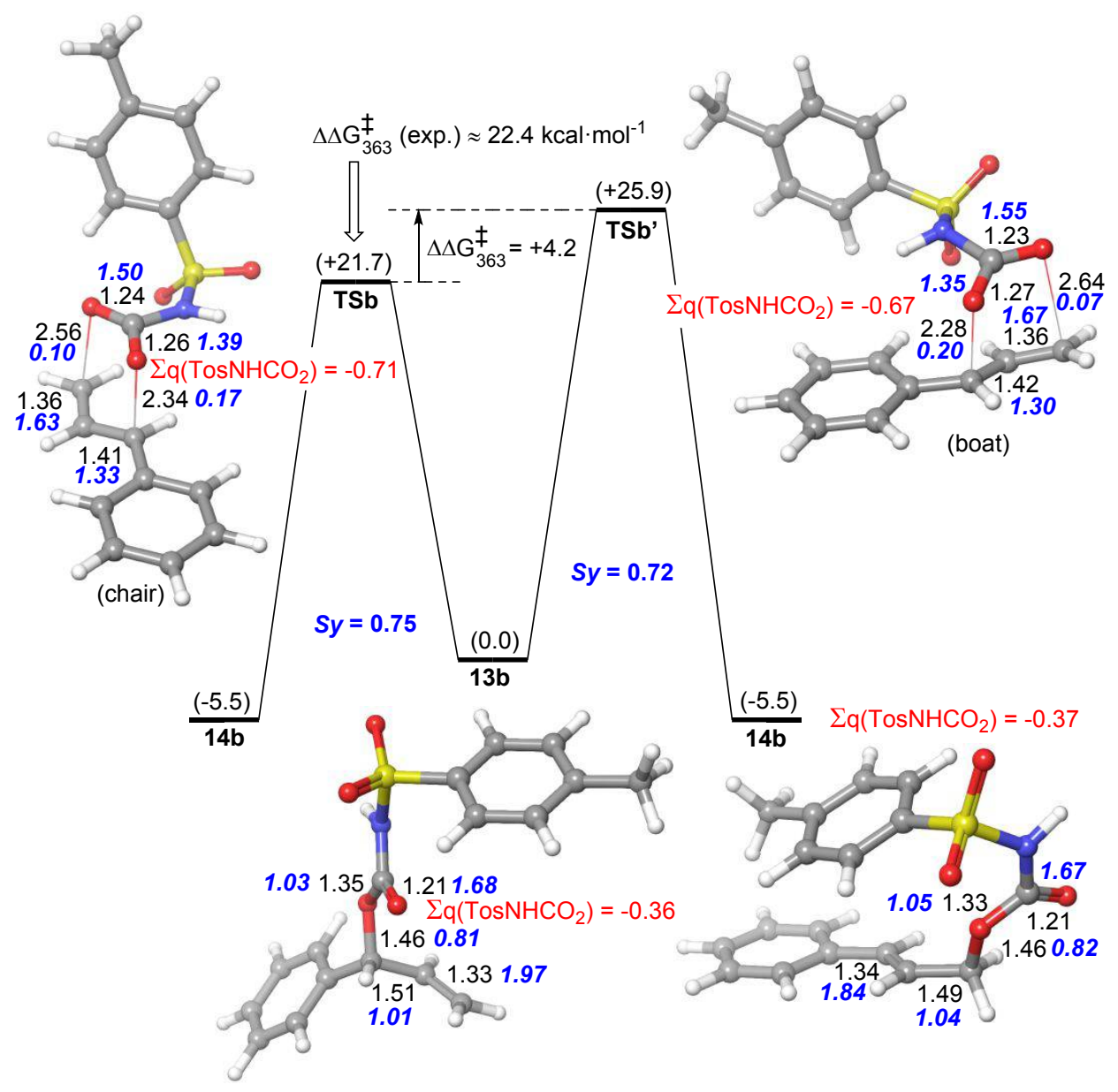

Figure 7. Reaction profiles of the thermal rearrangement of 1-phenylallyl tosylcarbamate 13b to yield cinnamyl tosylcarbamate $\mathbf{1 4 b}$. All stationary points were calculated at the B3LYPD3(PCM,solvent=toluene) $/ 6-311++\mathrm{G}(\mathrm{d}, \mathrm{p})$ level of theory. Numbers in parentheses are the relative free energies, in $\mathrm{kcal} / \mathrm{mol}$, calculated at $363.15 \mathrm{~K}$ with respect to $\mathbf{1 3 b}$. The experimental Gibbs activation energy, estimated at the same temperature, is also provided. 
Bond distances are given in $\AA$. $\Sigma \mathrm{q}\left(\mathrm{CO}_{2}\right)$ values, displayed in red, correspond to the natural charges of the carboxy moieties and are given in a. u. Numbers in blue correspond to the respective bond orders. The Sy parameter stands for the synchronicity of each elementary process via TSb and TSb'. For a perfectly synchronous transformation, $S y=1$ (see text).

The reaction coordinate associated with the [3,3] sigmatropic rearrangement of 1phenylallyl tosylcarbamate $\mathbf{1 3 b}$ to yield cinnamyl tosylcarbamate $14 \mathbf{b}(R=H)$ was analyzed first. The chief features of this reaction are gathered in Figure 7. We found two transition structures TSb and TSb' corresponding to chair and boat geometries, respectively. The former saddle point was found to be ca. $4.2 \mathrm{kcal} / \mathrm{mol}$ less energetic than its boat congener, which indicates that only the $\mathbf{1 3 b} \rightarrow \mathbf{T S} b \rightarrow \mathbf{1 4 b}$ reaction coordinate is kinetically relevant. The theoretical activation energy was calculated to be $21.7 \mathrm{kcal} / \mathrm{mol}$. From the ${ }^{1} \mathrm{H}-\mathrm{NMR}$ data (vide supra), the experimental Gibbs activation energy at $363.15 \mathrm{~K}$ was estimated from the Eyring equation (eq.2) associated with $k_{\text {obs: }}$ :

$k_{o b s}=\kappa \frac{k_{B} \cdot 363.15}{h} \exp \left[-\frac{\Delta G_{363}^{ \pm}(\exp )}{R \cdot 363.15}\right]$

Assuming $\kappa^{\approx 1} 1$, the estimated activation energy was calculated to be $22.4 \mathrm{kcal} / \mathrm{mol}$, in good agreement with the computational value. In addition, using the bond orders associated with the suprafacial $[3,3]$ sigmatropic shift, we computed the earliness of the reaction path via TSb as the average of the degree of advancement $\delta B_{A V}$ of both saddle points, according to the following expression (eq.3):

$\delta B_{A V}=\frac{1}{6} \sum_{i=1}^{6} \delta B_{i}=\frac{1}{6} \sum_{i=1}^{6} \frac{B_{i}^{T S}-B_{i}^{R}}{B_{i}^{P}-B_{i}^{R}}$

where $B_{i}$ is the bond order of the $i$-th bond involved in the pericyclic reaction at the reactant $(R) \mathbf{1 3 b}$, transition state $(T S) \mathbf{T S b}$ and product $(P)$ 14b. For the $\mathbf{1 3 b} \rightarrow \mathbf{T S} \mathbf{b} \rightarrow \mathbf{1 4} \mathbf{b}$ transformation it was found that $\delta B_{A V}=0.42$. Since for an exactly midway transition structure $\delta B_{A V}=0.5$, this result indicates an slightly early saddle point, with $\Delta G_{\mathrm{rxn}}=-5.5 \mathrm{kcal} / \mathrm{mol}$. We also calculated the synchronicity $S y$ of the reaction as

$S y=1-\frac{1}{10} \sum_{i=1}^{6} \frac{\left|\delta B_{i}-\delta B_{A V}\right|}{\delta B_{A V}}$

According to this expression (eq.4), for a perfectly synchronous [3,3] sigmatropic reaction, $\delta B_{i}=\delta B_{A V}$ for any $\mathrm{i}=1,2, \ldots, 6$ and therefore $\left|\delta B_{i}-\delta B_{A V}\right|=0$ and $S y=1$. In our case, we obtained $S y=0.75$ for the $\mathbf{1 3 b} \rightarrow \mathbf{1 4 b}$ reaction mediated by $\mathbf{T S b}$, which suggests a noticeable 
asynchronicity. When the same reaction is mediated by $\mathbf{T S b}$, the reaction was computed to be slightly more asynchronous (see Figure 7). These results are in line with the geometries obtained for both saddle points, with two $\mathrm{C} \cdots \mathrm{O}$ distances associated with the bonds being broken and formed (see Figure 7). This partially asynchronous but still concerted character of the reaction mechanism agrees with the preservation of the chiral information contained in the starting enantiopure allyl alcohol (see Figure 3). Finally, the charge analysis of the carboxylate moiety along the reaction coordinate showed that this charge was ca. 0.2 e higher in the transition structures than in the reactant and product (Figure 7). This result points to relatively polar transition structures, with an associated positive charge delocalized in the allyl moiety. As a consequence, electron-withdrawing groups in the starting allyl alcohol should destabilize this partial cationic character, thus leading to higher activation energies. Likewise, electron releasing substituents should accelerate the sigmatropic rearrangement, in good agreement with our experimental results (see Tables 1-4).

We also performed the above described DFT study with tosylcarbamate $13 \mathbf{c}(\mathrm{R}=\mathrm{Cl})$ to yield 4-chlorocynnamyl tosylcarbamate 14c (see the Supporting Information for further details). The computed reaction profile for this series was similar to that found for $\mathrm{R}=\mathrm{H}$ case. As expected, the activation energy computed for the $13 \mathbf{c} \rightarrow \mathbf{1 4 c}$ reaction via TSc was calculated to be $22.6 \mathrm{kcal} / \mathrm{mol}$, a value slightly higher than that found for the parent $\mathbf{1 3 \mathbf { b }} \rightarrow$ 14b reaction. The excellent agreement between this latter computational value and the corresponding experimental estimate $(22.7 \mathrm{kcal} / \mathrm{mol}$, see the Supporting Information) reflects the reliability of our calculations and reproduces correctly the lower reaction rate with respect to the parent reaction $(\mathrm{R}=\mathrm{H})$ for allyl alcohols when $\mathrm{R}=\mathrm{Cl}$.

In order to analyze the reasons for the preference for the chair conformation in $\mathbf{T S b}$, we considered applying the distortion/interaction-activation strain model ${ }^{33}$ to both saddle points. However, the intramolecular nature of the sigmatropic rearrangement hampered the analysis in terms of interacting molecules. Therefore, we decomposed the activation energy $\Delta \mathrm{E}^{\ddagger}$ as the sum of the deformation (FDEF) and interaction (FINT) terms between two carboxylic (C) and allylic (A) fragments at transition structure TSb:

$\Delta E^{\ddagger}=\Delta E_{F D E F}^{\ddagger}+\Delta E_{F I N T}^{\ddagger}$

The deformation of both fragments can be envisaged as the sum of the zwitterionic (ZW) and diradical (DR) contributions of both fragments: 
$\Delta E_{F D E F}^{\ddagger}=X_{Z W} \Delta E_{Z W}^{\ddagger}+\left(1-X_{Z W}\right) \Delta E_{D R}^{\ddagger}$

where $X_{Z W}$ is the weight of the zwitterionic contribution, the corresponding diradical coefficient $X_{D R}$ satisfying the relation $X_{Z W}+X_{D R}=1$. Since for the DR structures the charges of both fragments are zero, we approximated the contribution of the $\mathrm{ZW}$ form as $X_{Z W}=\delta$, namely the NBO charge of the allylic fragment $\mathbf{A}$ in $\mathbf{T S b}$ (Figure 8).

The $\Delta E_{Z W}{ }_{W}$ term was computed as the sum of the single-point energies of isolated carboxylate $\left(\mathbf{C}^{-}\right)$and allyl cation $\left(\mathbf{A}^{+}\right)$fragments at the geometry of $\mathbf{T S b}$, with respect to the energy $E_{0}$ of the reactant $\mathbf{1 3 b}$ :

$\Delta E_{Z W}^{\text {zW }}=\left(\Delta E_{C}^{\ddagger}+\Delta E_{A}^{\ddagger}\right)-E_{0}$

The $\Delta E_{D R}^{ \pm}$term was computed in a similar way, but considering the contributions of the carboxy $(\mathbf{C} \cdot)$ and allyl $(\mathbf{A} \cdot)$ isolated radical fragments, also computed at the geometries of the transition state $\mathbf{T S b}$ :

$\Delta E_{D R}^{\ddagger}=\left(\Delta E_{C}^{\ddagger}+\Delta E_{A}^{\ddagger}\right)-E_{0}$

Our results indicate that both in the chair and boat conformations of TSb the contributions of the ZW forms are ca. $1 \mathrm{kcal} / \mathrm{mol}$ larger than those associated with the DR

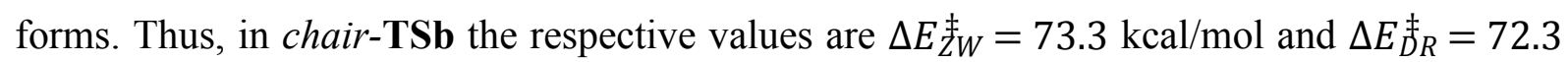
$\mathrm{kcal} / \mathrm{mol}$, whereas the corresponding values for boat-TSb are $\Delta E_{Z W}^{\neq}=78.4 \mathrm{kcal} / \mathrm{mol}$ and $\Delta E_{D R}^{\ddagger}=77.6 \mathrm{kcal} / \mathrm{mol}$. The computed total values of $\Delta E^{\ddagger}, \Delta E_{F D E F}^{\ddagger}$ and $\Delta E_{F I N T}^{\ddagger}$ terms of eq. (1) are shown in Figure 8. Our calculations indicate that the fragment deformation term $\triangle E_{F D E F}^{\ddagger}$ is $5.1 \mathrm{kcal} / \mathrm{mol}$ higher in boat-TSb than in chair-TSb, the difference in $\Delta E_{F I N T}^{\ddagger}$ being of only $1.2 \mathrm{kcal} / \mathrm{mol}$ in favor of boat-TSb. Therefore, in the boat geometry both the deformation (destabilizing) and interaction (stabilizing) terms between the $\mathbf{C}$ and $\mathbf{A}$ fragments are higher in magnitude because of closer steric, Coulombic and electronic contacts in boatTSb with respect to its chair congener. We conclude that $\triangle E_{F D E F}^{\neq}$is responsible for the preference for the chair conformation in these pericyclic transition structures, since the more congested boat geometry induces a larger departure of the $\mathbf{C}$ and $\mathbf{A}$ fragments from their respective optimal geometries. 

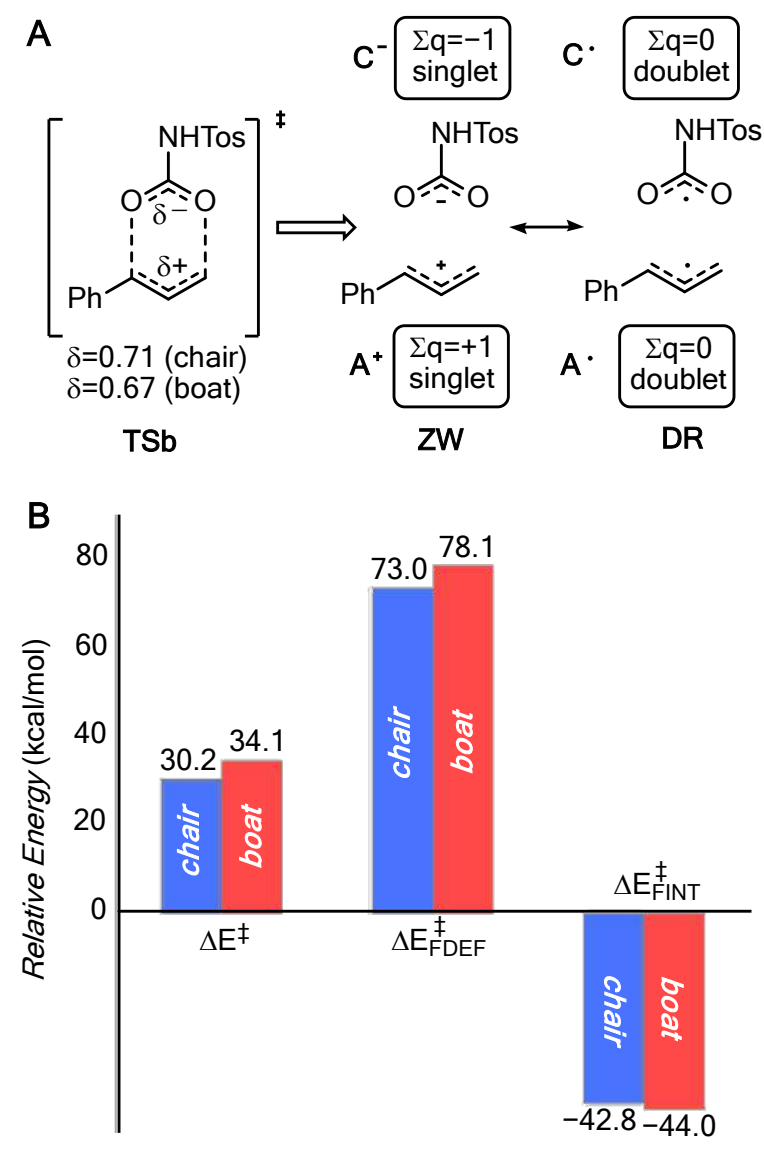

Figure 8. (A) Fragment deformation/interaction analysis (see text) of TSb in terms of resonant zwitterionic (ZW) and diradical (DR) contributions between carboxy $(\mathbf{C})$ and allyl (A) fragments. $\Sigma \mathrm{q}$ is the formal charge of the corresponding fragment. The expected $\left\langle S^{2}\right\rangle$ values, in atomic units (a.u.) are also given. The sum of NBO charges of each fragment at chair- and boat-TSb, in a.u., are denoted as $\delta$. (B) Calculated activation $\left(\Delta E^{\ddagger}\right)$, deformation ( $\left.\triangle E_{F D E F}^{\ddagger}\right)$ and interaction energies $\left(\triangle E_{F I N T}^{\neq}\right)$for the chair and boat conformations of $\mathbf{T S b}$, in $\mathrm{kcal} / \mathrm{mol}$.

In order to assess whether this relatively polar character of the sigmatropic shift can be extended to other para-substituted allyl alcohol derivatives, we computed at the B3LYPD3(SCRF, solvent=toluene) $/ 6-311++G(d, p)$ level the activation free energies associated with different reactants and we plotted these energies with respect to the combined Hammett parameter $^{34}\langle\sigma\rangle$ of the corresponding substituents in the form

$$
\langle\sigma\rangle=Z_{W} \cdot \sigma_{p}^{+}+\left(1-Z_{W}\right) \sigma_{p}
$$

where $\sigma_{p}^{+}$is the Taft resonance parameter for positive charges and $\sigma_{p}$ is the Hammett parameter for a para-substituent (Figure 9). Our results show a moderate linear correlation between the Gibbs activation energies and the combined polar Hammett-Taft parameter $\langle\sigma\rangle$. 
However, there is no linear correlation between the $\Delta \mathrm{G}_{\mathrm{a}}$ and $\Delta \mathrm{G}_{\mathrm{rxn}}$ values, ${ }^{35}$ as it is shown in Figure 9B. This result does not follow the behavior observed for other pericyclic reactions such as 1,4-dihydrogenations and [4+2] cycloadditions of aromatic molecules, ${ }^{36}$ thus suggesting that the relationship between activation and reaction energies is not reducible to Marcus-Hammond models. In our opinion, this supports our conclusion that the transition structures of these sigmatropic rearrangements follow a polar-radical carboxy/allyl model not directly connected to the reactants or products. Within this context, it is interesting to note that Houk and Ess $^{37}$ have shown a departure from the Marcus-Hammond framework in 1,3-dipolar reactions, in which the nature of the different dipoles generates different $\Delta H^{\ddagger} / \Delta H_{r x n}$ plots.

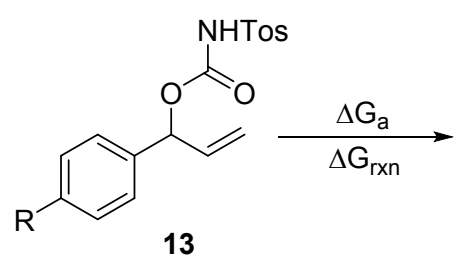

A

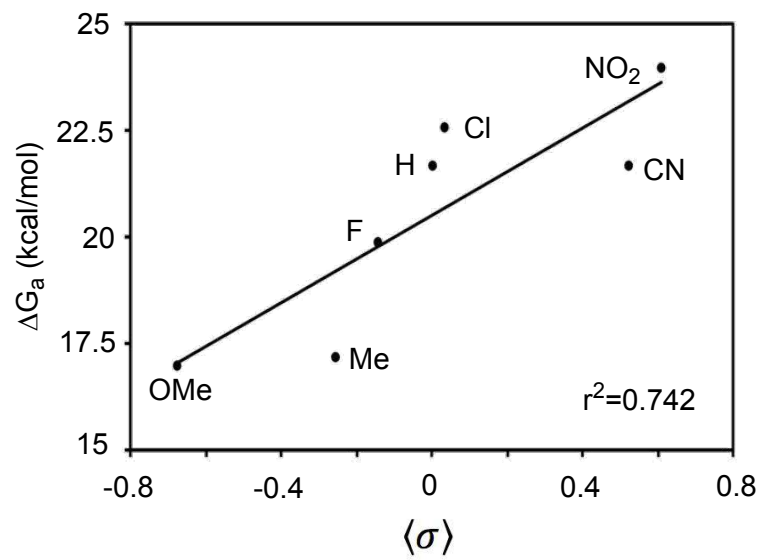

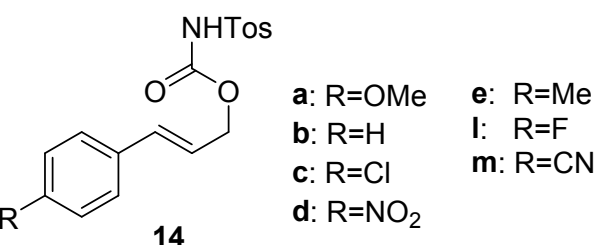

B

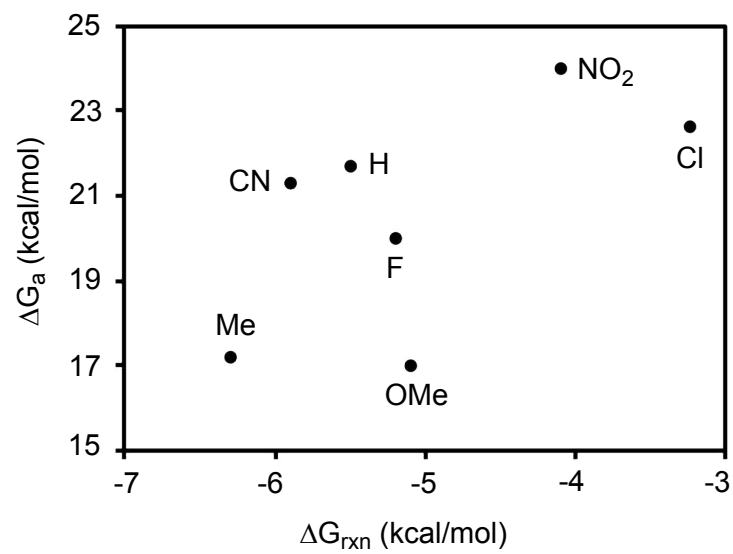

Figure 9. (A) Correlation between the calculated (B3LYP-D3(SCRF, solvent=toluene)/6$311++G(d, p)$ level of theory) activation energies $\left(\Delta G_{a}\right)$ for different para-substituents of allyl alcohol derivatives and the composite Hammett parameter $\langle\sigma\rangle$ (see text). (B) Plot of the calculated activation $\left(\Delta \mathrm{G}_{\mathrm{a}}\right)$ and reaction $\left(\Delta \mathrm{G}_{\mathrm{rxn}}\right)$ free energies (computed at $\left.363.15 \mathrm{~K}\right)$ for the substituents indicated in $(\mathrm{A})$.

Finally, we explored computationally the conversion of alcohols $\mathbf{1 7 a , b}$ into carbamates 18ab-bb (Scheme 5). As a model case, we chose the thermal transformation of (Z)-buta-1,3-dien-1-yl formate 29a into $(E)$ - or (Z)-31a (Figure 10A). From the s-trans conformation of (Z)-29a, the 1,3-dioxa-[3,3]-sigmatropic rearrangement gives rise to 
intermediate 30a via saddle point TS1a. This latter intermediate has a novel terminal $\mathrm{C}=\mathrm{C}$ bond and yields diene (E)-31a via TS2a, which in this model case is identical to TS1a. In turn, as we have seen in the previous cases, this model transition structure can adopt chair and boat geometries. Another possibility consists of a degenerate pseudopericyclic reaction ${ }^{27,28}$ not subjected to the Woodward-Hoffmann ${ }^{29}$ rules for thermal sigmatropic rearrangementsinvolving the $s$-cis conformation of (Z)-29a to yield again (Z)-31a (Figure 10A). This latter process should occur via $C_{s}$-symmetric transition structure TS3 by through interconversion between $\mathrm{C}-\mathrm{O} \sigma-$ bonds, $\mathrm{C}-\mathrm{C} \pi$-bonds and one of the lone pairs of one oxygen of the carboxy group. 
A
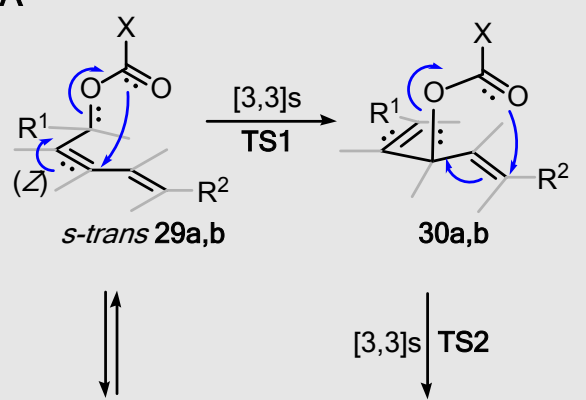<smiles>[X]C(=O)Oc1ccc([R])cc1</smiles>

$s-\operatorname{cis} 29 \mathrm{a}, \mathrm{b}$

a: $X=R^{1}=R^{2}=H$ ab: $\mathrm{X}=\mathrm{NHCOPh} ; \mathrm{R}^{1}=\mathrm{Ph}$; $\mathrm{R}^{2}=\mathrm{Me}$

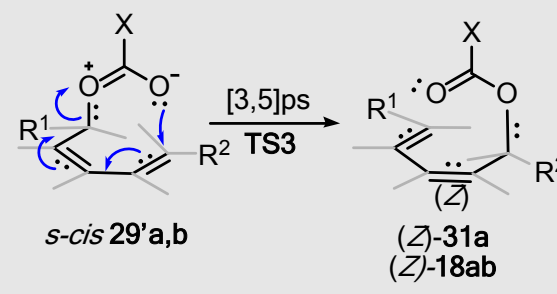

C

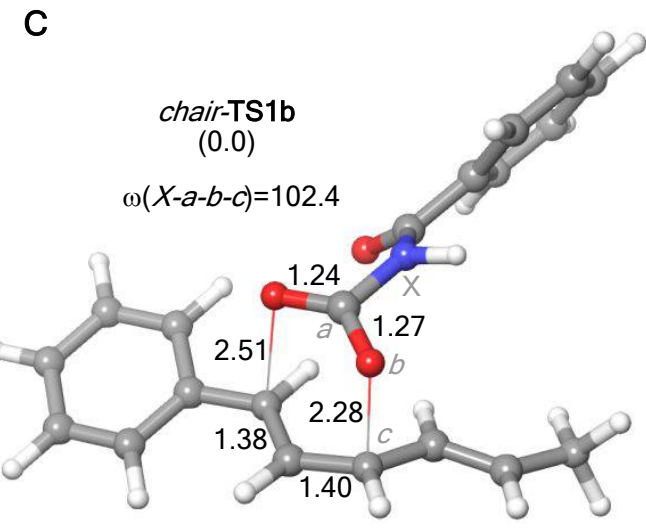

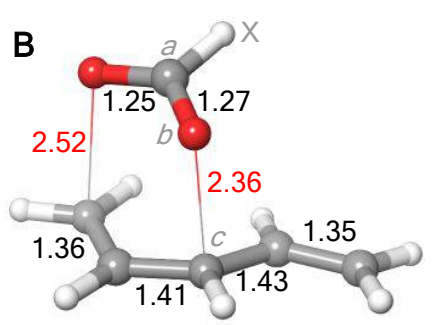

chair-TS1,2a (0.0)
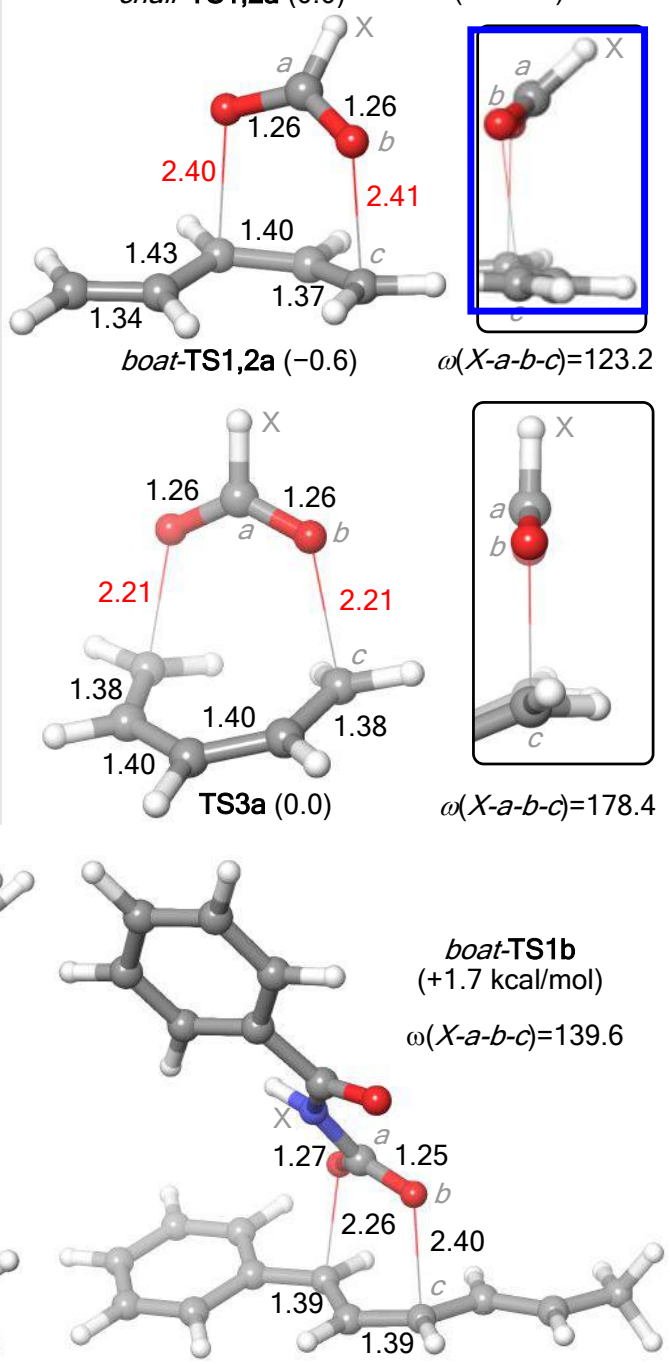

Figure 10. (A) Sequential vs. one-step $(3,3)$ and $(3,5)$ dioxa-rearrangements of model esters $(Z)-\mathbf{2 9 a}, \mathbf{b}$ to yield $(E)-\mathbf{3 1 a}, \mathbf{b}$ and $(Z)-31 \mathbf{a}, \mathbf{b}$. (B) Optimized geometries (B3LYP$\mathrm{D} 3\left(\mathrm{PCM}=\mathrm{CHCl}_{3}\right) / 6-311++\mathrm{G}(\mathrm{d}, \mathrm{p})$ level of theory) and relative energies of transition structures chair-TS1,2a, boat-TS1,2a and TS3a. (C) Chief geometric and energetic features (B3LYP$\mathrm{D} 3\left(\mathrm{PCM}=\mathrm{CHCl}_{3}\right) / 6-311++\mathrm{G}(\mathrm{d}, \mathrm{p}) / \mathrm{B} 3 \mathrm{LYP} / 6-31 \mathrm{G}(\mathrm{d})$ level of theory) of transition structures chair-TS1b and boat-TS1b. Bond distances are given in $\AA$. Numbers in parentheses are the relative energies, in $\mathrm{kcal} / \mathrm{mol}$. The dihedral angle $\omega$ (in deg.) is defined by the $X-a-b-c$ atoms.

Our calculations showed that, in effect, chair-TS12,a, boat-TS1,2a and TS3a are practically isoenergetic. In particular, the $[3,3]$ transition structures correspond to pericyclic 
supra,supra topologies, as indicated by the corresponding dihedral angles $\omega$ (Figure 10B). On the contrary, TS3a eludes the geometrically demanding supra, antara pericyclic topology by adopting a pseudopericyclic [3,5] geometry reflected by a $\omega$ value of ca. $180 \mathrm{deg}$. Next, we computed the realistic case associated with the conversion of alcohol (E,Z)-17a into carbamate $(E)$-18ab (Scheme 5) through analysis of the $(Z)-\mathbf{2 9 b} \rightarrow(E / Z)-\mathbf{1 8 a b}$ transformation. In this case, the [3,5] pseudopericyclic mechanism disappeared from the potential energy hypersurface and only the pericyclic $[3,3]$ mechanism survived. In addition, saddle point boatTS1b was calculated to lie $1.7 \mathrm{kcal} / \mathrm{mol}$ above its congener chair-TS1b (Figure 10C). These computational permitted us to conclude that, although the pseudopericyclic [3,5] mechanism is conceivable, in this particular case the conversion of (Z)-29b into $(E)$-18ab via two consecutive suprafacial $[3,3]$ processes is the only accessible mechanism. These results agree with the experimental findings summarized in Scheme 5, since a hypothetical pseudopericyclic [3,5] mechanism should preserve the Z-stereochemistry of the starting alcohol (Z)-17a.

\section{CONCLUSIONS}

In this paper, we have described a tandem reaction from 1-arylallyl alcohols involving an initial carbamoylation reaction followed by an unexpected metal-free 1,3-dioxa-[3,3]sigmatropic rearrangement for a non-conventional access to linear allyl carbamates. Scope and limitations of this one-pot process were carried out showing the crucial importance of the electron density from aromatic ring as well as the nature of the isocyanate used. The synthetic interest of this methodology is all greater given that this kind of sigmatropic rearrangement can occur rapidly under mild reaction conditions (room temperature) and with a complete transfer of chiral information.

The mechanism of these [3,3] sigmatropic reactions has been investigated both experimentally and computationally. ${ }^{1} \mathrm{H}-\mathrm{NMR}$ studies show the very fast conversion of starting alcohols $\mathbf{1 b}, \mathbf{c}$ to give rise to intermediate tosylcarbamates $\mathbf{1 3 b}, \mathbf{c}$ whose $[3,3]$ sigmatropic rearrangements yielded cinnamyl tosylcarbamates $\mathbf{1 4 b}, \mathbf{c}$ without any noticeable reaction intermediate. The corresponding first-order reaction rates showed a relative reactivity following the order $\mathrm{H}>\mathrm{Cl}$. Computational DFT studies showed asynchronous, but concerted, suprafacial processes mediated by chair transition structures, in agreement with the observed stereoselectivities with an enantiopure substrate and NMR experiments with a ${ }^{17} \mathrm{O}$ labeled 
substrate. These latter saddle points reflect correctly the relative reaction rates and activation energies and show a polar character, in which the carboxy moiety bears a significant negative charge.

\section{EXPERIMENTAL SECTION}

General Information and Materials. Tetrahydrofuran (THF) was distilled over sodium/benzophenone and dichloromethane (DCM) was distilled over $\mathrm{P}_{2} \mathrm{O}_{5}$. All other commercially available chemicals were used without further purification. NMR spectra were recorded at 300,400 or $500 \mathrm{MHz}$ for ${ }^{1} \mathrm{H}$ and 75, 101 or $126 \mathrm{MHz}$ for ${ }^{13} \mathrm{C}$. Chemical shifts of ${ }^{1} \mathrm{H}$ were referenced to $\mathrm{Me}_{4} \mathrm{Si}$ as internal reference. Data are represented as follows: chemical shift ( $\mathrm{ppm})$, multiplicity $(\mathrm{s}=$ singlet, $\mathrm{d}=$ doublet, $\mathrm{t}=$ triplet, $\mathrm{q}=$ quartet, $\mathrm{m}=$ multiplet, br s = broad singlet), coupling constant $J(\mathrm{~Hz})$ and integration. Assignments were done with the aid of DEPT 135, COSY and HSQC experiments. High-resolution mass spectra (HRMS) were recorded on a MicroTof-Q II or on a Q-Tof 2 using positive ion electrospray. Purifications on silica gel were carried out on silica gel 0.006-0.200 mm, $60 \AA$ Á. Infrared spectra were recorded on a FT-IR spectrometer equipped with a diamond detection and an ATR unit or a single reflection ATR module; wavenumbers are given in $\mathrm{cm}^{-1}$. Analytical thin layer chromatography was performed on Silica gel $60 \mathrm{~F}_{254}$ plates. Optical rotations were measured using $10-\mathrm{cm}$ cell at $22{ }^{\circ} \mathrm{C}$ (sodium D-line: $589 \mathrm{~nm}$ ), and the concentration is expressed in $\mathrm{g} / \mathrm{dL}$. Melting points were measured without correction on a digital melting point apparatus. All analytical high-performance liquid chromatography (HPLC) were performed, using Daicel Chiralpak IB column. 1-(Phenyl)prop-2-en-1-ol (1) is a commercialy available compound. The $\left[{ }^{17} \mathrm{O}\right]$ labelled $\mathrm{H}_{2} \mathrm{O}\left(11.1 \% \mathrm{H}_{2}{ }^{17} \mathrm{O}, 29.7 \% \mathrm{H}_{2}{ }^{18} \mathrm{O}\right.$ and $\left.59.2 \% \mathrm{H}_{2}{ }^{16} \mathrm{O}\right)$ was purchased from Cortecnet. NMR spectra were recorded at $68 \mathrm{MHz}$ for ${ }^{17} \mathrm{O}$.

General procedure for the synthesis of allylic alcohols 1,5 and 20 . To a solution of aldehyde $(1.50 \mathrm{mmol})$ in THF $(10 \mathrm{~mL})$ was slowly added at $0^{\circ} \mathrm{C}$ a solution of vinyl or phenylmagnesium bromide in THF $(1.80 \mathrm{mmol}, 1 \mathrm{M})$. The reaction mixture was stirred at room temperature for 16 hours after which a saturated $\mathrm{NH}_{4} \mathrm{Cl}$ solution $(5 \mathrm{~mL})$ was added. The aqueous layer was extracted with $\mathrm{Et}_{2} \mathrm{O}(4 \times 10 \mathrm{~mL})$. The organic layers were dried over $\mathrm{MgSO}_{4}$, filtered and concentrated in vacuo. The residue was purified by flash column chromatography on silica gel to afford the corresponding product.

1-(4-Methoxyphenyl)prop-2-en-1-ol (1a). ${ }^{38}$ Prepared from 4-methoxybenzaldehyde and vinyl magnesium bromide. Purified using a hexane/ethyl acetate mixture $\left(80 / 20, R_{f} 0.25\right)$ as eluent. The product was isolated as a yellow oil $(210 \mathrm{mg})$ in $85 \%$ yield. ${ }^{1} \mathrm{H}$ NMR $\left(400 \mathrm{MHz}, \mathrm{CDCl}_{3}\right) \delta 7.30(\mathrm{~d}, J=8.2 \mathrm{~Hz}, 2 \mathrm{H}), 6.89(\mathrm{~d}$, $J=8.2 \mathrm{~Hz}, 2 \mathrm{H}), 6.05(\mathrm{ddd}, J=17.2,10.3,5.9 \mathrm{~Hz}, 1 \mathrm{H}), 5.34$ (dd, $J=17.2,1.7 \mathrm{~Hz}, 1 \mathrm{H}), 5.22-5.12(\mathrm{~m}, 2 \mathrm{H}), 3.81$ (s, 3H), 1.89-1.86 (br s, 1H).

1-(4-Chlorophenyl)prop-2-en-1-ol (1c). ${ }^{39}$ Prepared from 4-chlorobenzaldehyde and vinyl magnesium bromide. Purified using a hexane/ethyl acetate mixture $\left(85 / 15, R_{f} 0.30\right)$ as eluent. The product was isolated as a pale yellow oil $(187 \mathrm{mg})$ in $74 \%$ yield. ${ }^{1} \mathrm{H}$ NMR $\left(300 \mathrm{MHz}, \mathrm{CDCl}_{3}\right): \delta 7.33-7.31(\mathrm{~m}, 4 \mathrm{H}), 6.01$ (ddd, $J=17.0$, $10.1,6.1 \mathrm{~Hz}, 1 \mathrm{H}), 5.34$ (dt, $J=17.0,1.2 \mathrm{~Hz}, 1 \mathrm{H}), 5.25-5.15$ (m, 2H), 1.95 (d, $J=3.7 \mathrm{~Hz}, 1 \mathrm{H})$.

1-(4-Nitrophenyl)prop-2-en-1-ol (1d). ${ }^{40}$ Prepared from 4-nitrobenzaldehyde and vinyl magnesium bromide. Purified using a hexane/ethyl acetate mixture $\left(80 / 20, R_{f} 0.20\right)$ as eluent. The product was isolated as an 
orange oil $(81 \mathrm{mg})$ in $30 \%$ yield. ${ }^{1} \mathrm{H}$ NMR $\left(400 \mathrm{MHz}, \mathrm{CDCl}_{3}\right): \delta 8.15(\mathrm{~d}, J=8.7 \mathrm{~Hz}, 2 \mathrm{H}), 7.52(\mathrm{~d}, J=8.7 \mathrm{~Hz}$, 2H), $5.96(\mathrm{ddd}, J=17.1,10.2,6.4 \mathrm{~Hz}, 1 \mathrm{H}), 5.36(\mathrm{ddd}, J=17.1,1.2,1.2 \mathrm{~Hz}, 1 \mathrm{H}), 5.28(\mathrm{~d}, J=6.4 \mathrm{~Hz}, 1 \mathrm{H}), 5.23$ (ddd, $J=10.3,1.1,1.1 \mathrm{~Hz}, 1 \mathrm{H}), 2.67-2.65$ (br s, 1H).

1-(4-Methylphenyl)prop-2-en-1-ol (1e)..$^{41}$ Prepared from 4-methylbenzaldehyde and vinyl magnesium bromide. Purified using a hexane/ethyl acetate mixture $\left(80 / 20, R_{f} 0.32\right)$ as eluent. The product was isolated as a yellow oil $(218 \mathrm{mg})$ in 98\% yield. ${ }^{1} \mathrm{H}$ NMR (400 MHz, $\left.\mathrm{CDCl}_{3}\right): \delta 7.26(\mathrm{~d}, J=7.5 \mathrm{~Hz}, 2 \mathrm{H}), 7.18(\mathrm{~d}, J=7.5 \mathrm{~Hz}$, 2H), 6.05 (ddd, $J=17.1,10.2,6.0 \mathrm{~Hz}, 1 \mathrm{H}), 5.35(\mathrm{~d}, J=17.1 \mathrm{~Hz}, 1 \mathrm{H}), 5.21-5.17(\mathrm{~m}, 2 \mathrm{H}), 2.35(\mathrm{~s}, 3 \mathrm{H}), 1.93(\mathrm{~d}, J$ $=6.0 \mathrm{~Hz}, 1 \mathrm{H})$.

1-(4-Benzyloxyphenyl)prop-2-en-1-ol (1f). ${ }^{42}$ Prepared from 4-benzyloxybenzaldehyde and vinyl magnesium bromide. Purified using a hexane/ethyl acetate mixture $\left(75 / 25, R_{f} 0.30\right)$ as eluent. The product was isolated as a colorless oil $(284 \mathrm{mg})$ in $79 \%$ yield. ${ }^{1} \mathrm{H} \quad \mathrm{NMR} \quad\left(400 \quad \mathrm{MHz}, \mathrm{CDCl}_{3}\right)$ : $\delta 7.48-7.35(\mathrm{~m}, 5 \mathrm{H}), 7.35-7.22(\mathrm{~m}, 2 \mathrm{H}), 6.97(\mathrm{~d}, J=8.3 \mathrm{~Hz}, 2 \mathrm{H}), 6.05$ (ddd, $J=17.1,10.3,5.9 \mathrm{~Hz}, 1 \mathrm{H}), 5.34$ $(\mathrm{d}, J=17.1 \mathrm{~Hz}, 1 \mathrm{H}), 5.21-5.15(\mathrm{~m}, 2 \mathrm{H}), 5.07(\mathrm{~s}, 2 \mathrm{H}), 1.86(\mathrm{~d}, J=3.4 \mathrm{~Hz}, 1 \mathrm{H})$.

1-(2-Methoxyphenyl)prop-2-en-1-ol (1g).43 Prepared from 2-methoxybenzaldehyde and vinyl magnesium bromide. Purified using a hexane/ethyl acetate mixture $\left(85 / 15, R_{f} 0.44\right)$ as eluent. The product was isolated as a colorless oil $(172 \mathrm{mg})$ in $70 \%$ yield. ${ }^{1} \mathrm{H}$ NMR $\left(400 \mathrm{MHz}, \mathrm{CDCl}_{3}\right): \delta 7.32-7.25(\mathrm{~m}, 2 \mathrm{H}), 7.01-6.94$ (m, 1H), $6.90(\mathrm{~d}, J=8.2 \mathrm{~Hz}, 1 \mathrm{H}), 6.14(\mathrm{ddd}, J=17.2,10.4,5.6 \mathrm{~Hz}, 1 \mathrm{H}), 5.41(\mathrm{dd}, J=5.6,5.6 \mathrm{~Hz}, 1 \mathrm{H}), 5.31(\mathrm{dd}$, $J=17.2,4.4 \mathrm{~Hz}, 1 \mathrm{H}), 5.17(\mathrm{dd}, J=10.4,4.4 \mathrm{~Hz}, 1 \mathrm{H}), 3.87$ (s, 3H), 2.77 (dd, $J=4.5,3.8 \mathrm{~Hz}, 1 \mathrm{H})$.

1-(2,3-Dihydrobenzofuran-5-yl)prop-2-en-1-ol (1h). ${ }^{44}$ Prepared from 2,3-dihydrobenzofuran-5carboxaldehyde and vinyl magnesium bromide. Purified using a hexane/ethyl acetate mixture $\left(80 / 20, R_{f} 0.33\right)$ as eluent. The product was isolated as a colorless oil $(259 \mathrm{mg})$ in $98 \%$ yield. ${ }^{1} \mathrm{H} \mathrm{NMR}\left(400 \mathrm{MHz}, \mathrm{CDCl}_{3}\right): \delta 7.32-$ $7.29(\mathrm{~m}, 1 \mathrm{H}), 7.16(\mathrm{~d}, J=8.2 \mathrm{~Hz}, 1 \mathrm{H}), 6.81(\mathrm{~d}, J=8.2 \mathrm{~Hz}, 1 \mathrm{H}), 6.10(\mathrm{ddd}, J=16.7,10.3,5.8 \mathrm{~Hz}, 1 \mathrm{H}), 5.34$ (ddd, $J=17.1,1.4,1.4 \mathrm{~Hz}, 1 \mathrm{H}), 5.24(\mathrm{ddd}, J=10.4,1.4,1.4 \mathrm{~Hz}, 1 \mathrm{H}), 5.19(\mathrm{~d}, J=5.8 \mathrm{~Hz}, 1 \mathrm{H}), 4.63(\mathrm{t}, J=8.7$ $\mathrm{Hz}, 2 \mathrm{H}), 3.26$ (t, $J=8.7 \mathrm{~Hz}, 2 \mathrm{H}), 1.92-1.86$ (br s, 1H).

1-(3,4-Dimethoxyphenyl)prop-2-en-1-ol (1i). ${ }^{45}$ Prepared from 3,4-dimethoxybenzaldehyde and vinyl magnesium bromide. Purified using a hexane/ethyl acetate mixture $\left(70 / 30, R_{f} 0.27\right)$ as eluent. The product was isolated as a pale yellow oil $(117 \mathrm{mg})$ in $40 \%$ yield. ${ }^{1} \mathrm{H}$ NMR $\left(400 \mathrm{MHz}, \mathrm{CDCl}_{3}\right): \delta 6.94-6.89(\mathrm{~m}, 2 \mathrm{H}), 6.85(\mathrm{~d}$, $J=7.8 \mathrm{~Hz}, 1 \mathrm{H}), 6.05(\mathrm{ddd}, J=17.1,10.4,5.9 \mathrm{~Hz}, 1 \mathrm{H}), 5.36(\mathrm{~d}, J=17.1 \mathrm{~Hz}, 1 \mathrm{H}), 5.20(\mathrm{~d}, J=10.4 \mathrm{~Hz}, 1 \mathrm{H}), 5.17$ $(\mathrm{d}, J=5.9 \mathrm{~Hz}, 1 \mathrm{H}), 3.89(\mathrm{~s}, 3 \mathrm{H}), 3.88(\mathrm{~s}, 3 \mathrm{H}), 1.96-1.90(\mathrm{br} \mathrm{s}, 1 \mathrm{H})$.

1-(3-(Benzyloxy)-4-methoxyphenyl)prop-2-en-1-ol (1j). Prepared from 3-benzyloxy-4methoxybenzaldehyde and vinyl magnesium bromide. Purified using a hexane/ethyl acetate mixture $\left(80 / 20, R_{f}\right.$ $0.21)$ as eluent. The product was isolated as a pale yellow oil $(324 \mathrm{mg})$ in $80 \%$ yield. ${ }^{1} \mathrm{H} \mathrm{NMR}(400 \mathrm{MHz}$, $\left.\mathrm{CDCl}_{3}\right): \delta 7.45(\mathrm{~d}, J=7.5 \mathrm{~Hz}, 2 \mathrm{H}), 7.36(\mathrm{dd}, J=7.4,7.4 \mathrm{~Hz}, 2 \mathrm{H}), 7.31$ (d, $\left.J=7.2 \mathrm{~Hz}, 1 \mathrm{H}\right), 6.96(\mathrm{~s}, 1 \mathrm{H}), 6.94-$ $6.90(\mathrm{~m}, 1 \mathrm{H}), 6.87(\mathrm{~d}, J=8.2 \mathrm{~Hz}, 1 \mathrm{H}), 5.99$ (ddd, $J=17.2,10.3,5.7 \mathrm{~Hz}, 1 \mathrm{H}), 5.30$ (d, $J=17.2 \mathrm{~Hz}, 1 \mathrm{H}), 5.19$ $5.16(\mathrm{~m}, 1 \mathrm{H}), 5.14(\mathrm{~s}, 2 \mathrm{H}), 5.12-5.10(\mathrm{~m}, 1 \mathrm{H}), 3.87(\mathrm{~s}, 3 \mathrm{H}), 1.87(\mathrm{~d}, J=3.8 \mathrm{~Hz}, 1 \mathrm{H}) .{ }^{13} \mathrm{C}\{1 \mathrm{H}\} \mathrm{NMR}(101 \mathrm{MHz}$, $\left.\mathrm{CDCl}_{3}\right): \delta 149.1,148.1,140.3,136.9,135.3,128.4,127.7,127.4,119.2,114.6,112.3(\mathrm{~d}, J=5.7 \mathrm{~Hz}), 111.6(\mathrm{~d}, J$ $=4.6 \mathrm{~Hz}), 74.6,70.9,55.9$. IR $\left(\mathrm{cm}^{-1}\right) 3488,3054,1511,1263,1157,1135,1021,730,698 . \mathrm{HRMS}(\mathrm{ESI}): \mathrm{m} / z$ calcd. for $\mathrm{C}_{17} \mathrm{H}_{19} \mathrm{O}_{3}[\mathrm{M}+\mathrm{H}]^{+}$271.1334; found: 271.1335 . 
1-(Benzo[d][1,3]dioxol-5-yl)prop-2-en-1-ol (1k). ${ }^{46}$ Prepared from piperonal and vinyl magnesium bromide. Purified using a hexane/ethyl acetate mixture $\left(90 / 10, R_{f} 0.17\right)$ as eluent. The product was isolated as a colorless oil (203 mg) in 76\% yield. ${ }^{1} \mathrm{H}$ NMR (400 MHz, $\left.\mathrm{CDCl}_{3}\right): \delta 6.88(\mathrm{~d}, J=1.6 \mathrm{~Hz}, 1 \mathrm{H}), 6.83(\mathrm{dd}, J=8.0$, $1.6 \mathrm{~Hz}, 1 \mathrm{H}), 6.78(\mathrm{~d}, J=8.0 \mathrm{~Hz}, 1 \mathrm{H}), 6.02(\mathrm{ddd}, J=17.1,10.3,5.9 \mathrm{~Hz}, 1 \mathrm{H}), 5.95(\mathrm{~s}, 2 \mathrm{H}), 5.34$ (ddd, $J=17.1$, $1.4,1.4 \mathrm{~Hz}, 1 \mathrm{H}), 5.19$ (ddd, $J=10.4,1.4,1.4 \mathrm{~Hz}, 1 \mathrm{H}), 5.13(\mathrm{~m}, 1 \mathrm{H}), 1.88(\mathrm{~d}, J=3.6 \mathrm{~Hz}, 1 \mathrm{H})$.

(E)-1-(4-Methoxyphenyl)penta-1,4-dien-3-ol (5a). Prepared from (E)-3-(4-methoxyphenyl)-2-propenal and vinyl magnesium bromide. Purified using a hexane/ethyl acetate mixture $\left(75 / 25, R_{f} 0.24\right)$ as eluent. The product was isolated as a yellow oil $(242 \mathrm{mg})$ in $85 \%$ yield. ${ }^{1} \mathrm{H} \mathrm{NMR}\left(400 \mathrm{MHz}, \mathrm{CDCl}_{3}\right): \delta 7.33(\mathrm{~d}, J=8.7 \mathrm{~Hz}$, 2H), $6.85(\mathrm{~d}, J=8.7 \mathrm{~Hz}, 2 \mathrm{H}), 6.56(\mathrm{~d}, J=15.9 \mathrm{~Hz}, 1 \mathrm{H}), 6.10(\mathrm{dd}, J=15.9,6.6 \mathrm{~Hz}, 1 \mathrm{H}), 5.98(\mathrm{ddd}, J=17.2$, $10.4,5.8 \mathrm{~Hz}, 1 \mathrm{H}), 5.33$ (ddd, $J=17.2,1.4,1.4 \mathrm{~Hz}, 1 \mathrm{H}), 5.19$ (ddd, $J=10.5,1.4,1.4 \mathrm{~Hz}, 1 \mathrm{H}), 4.80-4.78$ (m, $1 \mathrm{H})$, $3.81(\mathrm{~s}, 3 \mathrm{H}), 1.77-1.73$ (br s, $1 \mathrm{H}) .{ }^{13} \mathrm{C}\{1 \mathrm{H}\} \mathrm{NMR}\left(101 \mathrm{MHz}, \mathrm{CDCl}_{3}\right): \delta 159.5,139.6,130.6,129.5,128.3,127.9$, 115.3, 114.1, 74.1, 55.4. IR ( $\left.\mathrm{cm}^{-1}\right) 3422,2837,1606,1510,1247,1174,1031,967,732,702$. HRMS (ESI): $m / z$ calcd. for $\mathrm{C}_{12} \mathrm{H}_{13} \mathrm{O}\left[\mathrm{M}+\mathrm{H}-\mathrm{H}_{2} \mathrm{O}\right]^{+}$173.0960; found 173.0963.

(E)-1-Phenylpenta-1,4-dien-3-ol (5b). ${ }^{47}$ Prepared from (E)-3-phenyl-2-propenal and vinyl magnesium bromide. Purified using a hexane/ethyl acetate mixture $\left(85 / 15, R_{f} 0.23\right)$ as eluent. The product was isolated as a pale yellow oil $(204 \mathrm{mg})$ in $85 \%$ yield. ${ }^{1} \mathrm{H}$ NMR (300 MHz, $\left.\mathrm{CDCl}_{3}\right): \delta 7.42-7.36(\mathrm{~m}, 2 \mathrm{H}), 7.35-7.30(\mathrm{~m}, 1 \mathrm{H})$, $7.30-7.20(\mathrm{~m}, 2 \mathrm{H}), 6.62(\mathrm{~d}, J=16.1 \mathrm{~Hz}, 1 \mathrm{H}), 6.23(\mathrm{dd}, J=16.1,6.4 \mathrm{~Hz}, 1 \mathrm{H}), 5.98(\mathrm{ddd}, J=17.2,10.4,5.9 \mathrm{~Hz}$, 1H), 5.34 (ddd, $J=17.2,1.4,1.4 \mathrm{~Hz}, 1 \mathrm{H}), 5.20$ (ddd, $J=10.4,1.3,1.3 \mathrm{~Hz}, 1 \mathrm{H}), 4.89-4.76(\mathrm{~m}, 1 \mathrm{H}), 1.77-1.74$ $(\mathrm{m}, 1 \mathrm{H})$.

(E)-1-(4-Chlorophenyl)penta-1,4-dien-3-ol (5c). Prepared from (E)-3-(4-chlorophenyl)-2-propenal and vinyl magnesium bromide. Purified using a hexane/ethyl acetate mixture $\left(75 / 25, R_{f} 0.35\right)$ as eluent. The product was isolated as a pale yellow oil $(213 \mathrm{mg})$ in $73 \%$ yield. ${ }^{1} \mathrm{H}$ NMR $\left(400 \mathrm{MHz}, \mathrm{CDCl}_{3}\right): \delta 7.34-7.24(\mathrm{~m}, 4 \mathrm{H}), 6.57$ $(\mathrm{dd}, J=16.0,1.4 \mathrm{~Hz}, 1 \mathrm{H}), 6.21(\mathrm{dd}, J=16.0,6.3 \mathrm{~Hz}, 1 \mathrm{H}), 5.96(\mathrm{ddd}, J=17.4,10.3,6.0 \mathrm{~Hz}, 1 \mathrm{H}), 5.34(\mathrm{ddd}, J=$ 17.4, 1.3, $1.3 \mathrm{~Hz}, 1 \mathrm{H}), 5.21$ (ddd, $J=10.4,1.3,1.3 \mathrm{~Hz}, 1 \mathrm{H}), 4.83-4.79(\mathrm{~m}, 1 \mathrm{H}) .{ }^{13} \mathrm{C}\{1 \mathrm{H}\} \mathrm{NMR}(101 \mathrm{MHz}$, $\left.\mathrm{CDCl}_{3}\right): \delta 139.1,135.1,133.3,131.1,129.4,128.7,127.7,115.5,73.5 . \mathrm{IR}\left(\mathrm{cm}^{-1}\right) 3271,3086,1638,1588,1488$, 1085, 1008, 967, 924, 805. HRMS (ESI): $m / z$ calcd. for $\mathrm{C}_{11} \mathrm{H}_{10} \mathrm{Cl}\left[\mathrm{M}+\mathrm{H}_{-} \mathrm{H}_{2} \mathrm{O}\right]^{+}$177.0467; found 177.0469.

(E)-1-(4-Nitrophenyl)penta-1,4-dien-3-ol (5d). ${ }^{48}$ Prepared from (E)-3-(4-nitrophenyl)-2-propenal and vinyl magnesium bromide. Purified using a hexane/ethyl acetate mixture $\left(75 / 25, R_{f} 0.24\right)$ as eluent. The product was isolated as an orange oil $(123 \mathrm{mg})$ in $40 \%$ yield. ${ }^{1} \mathrm{H}$ NMR $\left(400 \mathrm{MHz}, \mathrm{CDCl}_{3}\right): \delta 8.21-8.16(\mathrm{~m}, 2 \mathrm{H}), 7.56-$ $7.47(\mathrm{~m}, 2 \mathrm{H}), 6.71(\mathrm{~d}, J=16.9 \mathrm{~Hz}, 1 \mathrm{H}), 6.42$ (dd, $J=16.9,5.8 \mathrm{~Hz}, 1 \mathrm{H}), 5.97$ (ddd, $J=17.1,10.3,6.1 \mathrm{~Hz}, 1 \mathrm{H})$, $5.38(\mathrm{ddd}, J=17.1,1.2,1.2 \mathrm{~Hz}, 1 \mathrm{H}), 5.25(\mathrm{ddd}, J=10.3,1.2,1.2 \mathrm{~Hz}, 1 \mathrm{H}), 4.93-4.82(\mathrm{~m}, 1 \mathrm{H}), 1.83(\mathrm{~d}, J=4.2$ $\mathrm{Hz}, 1 \mathrm{H})$.

Racemic (E)-1-phenylbut-2-enol (20). Prepared from (E)-crotonaldehyde and phenylmagnesium bromide. Purified using a hexane/ethyl acetate mixture $\left(80 / 20, R_{f} 0.25\right)$ as eluent. The product was isolated as a yellow oil (190 mg) in 85\% yield. ${ }^{1} \mathrm{H}$ NMR (400 MHz, $\left.\mathrm{CDCl}_{3}\right): \delta 7.40-7.32(\mathrm{~m}, 4 \mathrm{H}), 7.31-7.27(\mathrm{~m}, 1 \mathrm{H}), 5.84-$ $5.63(\mathrm{~m}, 2 \mathrm{H}), 5.16(\mathrm{~d}, J=6.4 \mathrm{~Hz}, 1 \mathrm{H}), 1.72(\mathrm{~d}, J=5.9 \mathrm{~Hz}, 3 \mathrm{H}), 1.61(\mathrm{~d}, J=3.4 \mathrm{~Hz}, 1 \mathrm{H})$. The separation of enantiomers was carried out using a Daicel Chiralpak IB, hexane $/ i-\mathrm{PrOH}=99 / 1$, flow rate $=1 \mathrm{~mL} / \mathrm{min}, 220 \mathrm{~nm}$, the $(R, E)$ enantiomer $20 t_{\mathrm{R}}=24 \min \left(e e>99 \%,[\alpha]_{\mathrm{D}}=-16.9\left(c 0.95, \mathrm{CHCl}_{3}\right)\right)$, the $(S, E)$ enantiomer $20 \mathrm{t}_{\mathrm{R}}=28 \mathrm{~min}$ $\left(\right.$ ee $\left.98 \%,[\alpha]_{\mathrm{D}}=+24.6\left(c 0.65, \mathrm{CHCl}_{3}\right)\right) .{ }^{49}$ 

was added slowly. The reaction mixture was stirred during the time and temperature indicated in Table 1 and 2. Solvent was removed in vacuo and in some cases, intermediates have been identified.

(E)-3-(4-methoxyphenyl)allyl (2,2,2-trichloroacetyl)carbamate (3a). Prepared from allylic alcohol 1a $(\mathrm{rt}, 0.25 \mathrm{~h})$. The product was isolated as a colorless oil $(103 \mathrm{mg})$ in $98 \%$ yield and used in the next step without further purification. ${ }^{1} \mathrm{H}$ NMR $\left(300 \mathrm{MHz}, \mathrm{CDCl}_{3}\right): \delta 8.50-8.46$ (br s, $\left.1 \mathrm{H}\right), 7.34$ (d, $\left.J=8.7 \mathrm{~Hz}, 2 \mathrm{H}\right), 6.86(\mathrm{~d}, J=$ $8.7 \mathrm{~Hz}, 2 \mathrm{H}), 6.69$ (d, $J=15.8 \mathrm{~Hz}, 1 \mathrm{H}), 6.17(\mathrm{dt}, J=15.7,6.9 \mathrm{~Hz}, 1 \mathrm{H}), 4.88(\mathrm{dd}, J=6.9,1.2 \mathrm{~Hz}, 2 \mathrm{H}), 3.81(\mathrm{~s}$, $3 \mathrm{H}) .{ }^{13} \mathrm{C}\{1 \mathrm{H}\} \mathrm{NMR}\left(75 \mathrm{MHz}, \mathrm{CDCl}_{3}\right) \delta 159.9,157.9,149.8,136.2,128.1,118.9,114.1,91.8,68.3,55.3$.

(2E,4E)-5-phenylpenta-2,4-dien-1-yl (2,2,2-trichloroacetyl)carbamate (6b). Prepared from allylic alcohol $\mathbf{5 b}$ (rt, $4 \mathrm{~h})$. The product was isolated as a white solid (102 $\mathrm{mg})$ in $98 \%$ yield and used in the next step without further purification; $\mathrm{mp} 101-104{ }^{\circ} \mathrm{C} .{ }^{1} \mathrm{H}$ NMR $\left(300 \mathrm{MHz}, \mathrm{CDCl}_{3}\right) \delta 8.50-8.45$ (br s, $\left.1 \mathrm{H}\right), 7.42-7.36(\mathrm{~m}$, 2H), 7.35-7.28 (m, 2H), 7.27-7.21 (m, 1H), $6.76(\mathrm{dd}, J=15.6,10.2 \mathrm{~Hz}, 1 \mathrm{H}), 6.62(\mathrm{~d}, J=15.6 \mathrm{~Hz}, 1 \mathrm{H}), 6.53$ (ddd, $J=15.1,1.1,1.1 \mathrm{~Hz}, 1 \mathrm{H}), 5.88(\mathrm{dt}, J=15.1,6.9 \mathrm{~Hz}, 1 \mathrm{H}), 4.83(\mathrm{dd}, J=6.9,1.1 \mathrm{~Hz}, 2 \mathrm{H}) .{ }^{13} \mathrm{C}\{1 \mathrm{H}\} \mathrm{NMR}$ $\left(75 \mathrm{MHz}, \mathrm{CDCl}_{3}\right) \delta 157.8,149.7,136.7,135.1,128.7,128.2,127.2,126.7,124.7,91.8,67.7$.

To the resulting mixture or pure compound 3 or $6, \mathrm{~K}_{2} \mathrm{CO}_{3}(1.2 \mathrm{mmol})$ in a mixture of $\mathrm{MeOH}(1.6 \mathrm{~mL})$ and water $(0.4 \mathrm{~mL})$ was added. The solution was stirred at room temperature overnight and then $\mathrm{MeOH}$ was removed in vacuo. The aqueous layer was extracted with $\mathrm{CH}_{2} \mathrm{Cl}_{2}(4 \times 1 \mathrm{~mL})$. The organic layers were dried over $\mathrm{MgSO}_{4}$, filtered and concentrated in vacuo. The residue was purified by flash column chromatography on silica gel to afford the corresponding product.

(E)-3-(4-Methoxyphenyl)allyl carbamate (4a). Prepared from 3a. Purified using a hexane/ethyl acetate mixture (70/30, $\left.R_{f} 0.31\right)$ as eluent. The product was isolated as a white solid (45 $\mathrm{mg}$ ) in $73 \%$ yield from 1a. $\mathrm{mp}$ 131-134 ${ }^{\circ} \mathrm{C} .{ }^{1} \mathrm{H}$ NMR $\left(400 \mathrm{MHz}\right.$, acetone- $\left.d_{6}\right) \delta 7.35(\mathrm{~d}, J=8.8 \mathrm{~Hz}, 2 \mathrm{H}), 6.86(\mathrm{~d}, J=8.8 \mathrm{~Hz}, 2 \mathrm{H}), 6.57(\mathrm{~d}, J=$ $15.9 \mathrm{~Hz}, 1 \mathrm{H}), 6.17$ (dt, $J=15.9,6.3 \mathrm{~Hz}, 1 \mathrm{H}), 5.9-05.84$ (br s, 2H), 4.57 (dd, $J=6.3,1.5 \mathrm{~Hz}, 2 \mathrm{H}), 3.75$ (s, 3H). ${ }^{13} \mathrm{C}\{1 \mathrm{H}\} \mathrm{NMR}\left(126 \mathrm{MHz}, \mathrm{CD}_{3} \mathrm{OD}\right) \delta 161.0,159.8,134.1,130.5,128.8,122.7,115.0,66.4,55.7 . \mathrm{IR}\left(\mathrm{cm}^{-1}\right) 3423$, 3329, 3263, 3203, 2954, 2834, 1682, 1603, 1509, 1244, 1028, 510. HRMS (ESI): $m / z$ calcd. for $\mathrm{C}_{11} \mathrm{H}_{13} \mathrm{NO}_{3} \mathrm{Na}$ $[\mathrm{M}+\mathrm{Na}]^{+}$230.0793; found 230.0789 .

(E)-3-(phenyl)allyl carbamate (4b). ${ }^{14 \mathrm{~d}}$ Prepared from the commercially available 1-(Phenyl)prop-2-en-1-ol $\left(90{ }^{\circ} \mathrm{C}, 16 \mathrm{~h}\right)$. Purified using a hexane/ethyl acetate mixture $\left(70 / 30, R_{f} 0.28\right)$ as eluent. The product was isolated as a white solid $(49 \mathrm{mg})$ in $92 \%$ yield. mp $116-119{ }^{\circ} \mathrm{C} .{ }^{1} \mathrm{H} \mathrm{NMR}\left(400 \mathrm{MHz}, \mathrm{CDCl}_{3}\right) \delta$ $7.37(\mathrm{~d}, J=7.1 \mathrm{~Hz}, 2 \mathrm{H}), 7.33-7.27(\mathrm{~m}, 2 \mathrm{H}), 7.27-7.21(\mathrm{~m}, 1 \mathrm{H}), 6.63(\mathrm{~d}, J=15.9 \mathrm{~Hz}, 1 \mathrm{H}), 6.27(\mathrm{dt}, J=15.9,6.3$ $\mathrm{Hz}, 1 \mathrm{H}), 5.01-4.92$ (br s, $2 \mathrm{H}), 4.70(\mathrm{dd}, J=6.3,1.4 \mathrm{~Hz}, 2 \mathrm{H}) .{ }^{13} \mathrm{C}\{1 \mathrm{H}\} \mathrm{NMR}\left(126 \mathrm{MHz}, \mathrm{CDCl}_{3}\right) \delta 156.9,136.4$, 133.9, 128.7, 128.1, 126.7, 123.7, 65.8. HRMS (ESI): $m / z$ calcd. for $\mathrm{C}_{10} \mathrm{H}_{11} \mathrm{NO}_{2} \mathrm{Na}[\mathrm{M}+\mathrm{Na}]^{+}$200.0687; found 200.0686 .

(E)-3-(4-Chlorophenyl)allyl carbamate (4c). ${ }^{15 \mathrm{c}}$ Prepared from allylic alcohol $1 \mathrm{c}\left(90^{\circ} \mathrm{C}, 20 \mathrm{~h}\right)$. Purified using a hexane/ethyl acetate mixture $\left(70 / 30, R_{f} 0.27\right)$ as eluent. The product was isolated as a white solid (32 mg) 
in $50 \%$ yield. ${ }^{1} \mathrm{H}$ NMR $\left(400 \mathrm{MHz}, \mathrm{CDCl}_{3}\right) \delta 7.32-7.28(\mathrm{~m}, 4 \mathrm{H}), 6.60(\mathrm{~d}, J=15.9 \mathrm{~Hz}, 1 \mathrm{H}), 6.26(\mathrm{dt}, J=15.9,6.3$ $\mathrm{Hz}, 1 \mathrm{H}), 4.78-4.74$ (br s, 2H), 4.72 (dd, $J=6.3,1.4 \mathrm{~Hz}, 2 \mathrm{H})$.

(E)-3-(4-Nitrophenyl)allyl carbamate (4d). ${ }^{15 c}$ Prepared from allylic alcohol $1 \mathbf{d}\left(90{ }^{\circ} \mathrm{C}, 120 \mathrm{~h}\right)$. Purified using a hexane/ethyl acetate mixture $\left(70 / 30, R_{f} 0.10\right)$ as eluent. The product was isolated as a yellow solid (28 $\mathrm{mg})$ in $43 \%$ yield. ${ }^{1} \mathrm{H}$ NMR $\left(400 \mathrm{MHz}, \mathrm{CDCl}_{3}\right) \delta 8.19(\mathrm{~d}, J=8.5 \mathrm{~Hz}, 2 \mathrm{H}), 7.52(\mathrm{~d}, J=8.5 \mathrm{~Hz}, 2 \mathrm{H}), 6.71(\mathrm{~d}, J=$ $16.0 \mathrm{~Hz}, 1 \mathrm{H}), 6.46$ (dt, $J=16.0,5.8 \mathrm{~Hz}, 1 \mathrm{H}), 4.78(\mathrm{dd}, J=5.8,1.5 \mathrm{~Hz}, 2 \mathrm{H}), 4.73-4.66$ (br s, 2H).

(2E,4E)-5-(4-methoxyphenyl)penta-2,4-dien-1-yl carbamate (7a). Prepared from allylic alcohol 5a (rt, 2 h). Purified using a hexane/ethyl acetate mixture $\left(65 / 35, R_{f} 0.29\right)$ as eluent. The product was isolated as a pale yellow solid (17 mg) in $24 \%$ yield. mp $150-153{ }^{\circ} \mathrm{C} .{ }^{1} \mathrm{H} \mathrm{NMR}\left(400 \mathrm{MHz}, \mathrm{CDCl}_{3}\right) \delta 7.33(\mathrm{~d}, J=8.7 \mathrm{~Hz}, 2 \mathrm{H}), 6.85$ $(\mathrm{d}, J=8.7 \mathrm{~Hz}, 2 \mathrm{H}), 6.65(\mathrm{dd}, J=15.6,10.3 \mathrm{~Hz}, 1 \mathrm{H}), 6.53(\mathrm{~d}, J=15.6 \mathrm{~Hz}, 1 \mathrm{H}), 6.43(\mathrm{dd}, J=15.2,10.2 \mathrm{~Hz}, 1 \mathrm{H})$, $5.83(\mathrm{dt}, J=15.1,6.6 \mathrm{~Hz}, 1 \mathrm{H}), 4.71-4.67$ (br s, $2 \mathrm{H}), 4.64(\mathrm{dd}, J=6.6,1.3 \mathrm{~Hz}, 2 \mathrm{H}), 3.81(\mathrm{~s}, 3 \mathrm{H}) .{ }^{13} \mathrm{C}\{1 \mathrm{H}\} \mathrm{NMR}$ $\left(101 \mathrm{MHz}, \mathrm{CDCl}_{3}\right) \delta 159.6,156.8,134.9,133.5,129.9,127.9,126.2,125.9,114.36,65.7,55.5 . \mathrm{IR}\left(\mathrm{cm}^{-1}\right) 3436$, 3394, 3331, 3269, 3216, 3014, 2955, 1685, 1600, 1508, 1418, 1351, 1246, 1028, 988, 820, 552, 522. HRMS (ESI): $m / z$ calcd. for $\mathrm{C}_{13} \mathrm{H}_{15} \mathrm{NO}_{3} \mathrm{Na}[\mathrm{M}+\mathrm{Na}]^{+}$256.0950; found 256.0953.

(2E,4E)-5-phenylpenta-2,4-dien-1-yl carbamate (7b). ${ }^{20 \mathrm{~b}}$ Prepared from $\mathbf{6 b}$. Purified using a hexane/ethyl acetate mixture $\left(70 / 30, R_{f} 0.27\right)$ as eluent. The product was isolated as a yellow solid (40 $\left.\mathrm{mg}\right)$ in $65 \%$ yield from 5b. ${ }^{1} \mathrm{H}$ NMR $\left(400 \mathrm{MHz} \mathrm{CDCl}_{3}\right) \delta 7.45-7.37$ (m, 2H), 7.37-7.29 (m, 2H), 7.29-7.22 (m, 1H), $6.78(\mathrm{dd}, J=15.8$, $10.4 \mathrm{~Hz}, 1 \mathrm{H}), 6.59(\mathrm{~d}, J=15.8 \mathrm{~Hz}, 1 \mathrm{H}), 6.46(\mathrm{dd}, J=15.3,10.4 \mathrm{~Hz}, 1 \mathrm{H}), 5.89$ (dt, $J=15.3,6.4 \mathrm{~Hz}, 1 \mathrm{H}), 4.77-$ 4.68 (br s, 2H), 4.66 (dd, $J=6.6,1.5 \mathrm{~Hz}, 2 \mathrm{H})$.

(2E,4E)-5-(4-Chlorophenyl)penta-2,4-dien-1-yl carbamate (7c). Prepared from allylic alcohol 5c (rt, 4 h). Purified using a hexane/ethyl acetate mixture $\left(70 / 30, R_{f} 0.27\right)$ as eluent. The product was isolated as a pale yellow solid (53 mg) in 75\% yield. mp 167-170 ${ }^{\circ} \mathrm{C} .{ }^{1} \mathrm{H}$ NMR (400 MHz, $\left.\mathrm{CDCl}_{3}\right) \delta 7.36-7.24(\mathrm{~m}, 4 \mathrm{H}), 6.74(\mathrm{dd}$, $J=15.8,10.4 \mathrm{~Hz}, 1 \mathrm{H}), 6.53(\mathrm{~d}, J=15.7 \mathrm{~Hz}, 1 \mathrm{H}), 6.44(\mathrm{dd}, J=15.2,10.5 \mathrm{~Hz}, 1 \mathrm{H}), 5.90(\mathrm{dt}, J=15.2,6.4 \mathrm{~Hz}$, $1 \mathrm{H}), 4.66(\mathrm{dd}, J=6.4,1.5 \mathrm{~Hz}, 2 \mathrm{H}), 4.63-4.58$ (br s, $2 \mathrm{H}) .{ }^{13} \mathrm{C}\{1 \mathrm{H}\} \mathrm{NMR}\left(126 \mathrm{MHz}, \mathrm{CD}_{3} \mathrm{OD}\right) \delta 159.7,137.3$, 134.4, 134.2, 132.9, 130.0, 129.9, 129.8, 128.9, 65.8. IR ( $\left.\mathrm{cm}^{-1}\right)$ 3410, 3348, 3286, 3210, 3028, 2955, 1644, 1486, 1421, 1348, 1318, 1053, 986, 827, 508. HRMS (ESI): $m / z$ calcd. for $\mathrm{C}_{12} \mathrm{H}_{12} \mathrm{ClNO}_{2} \mathrm{Na}[\mathrm{M}+\mathrm{Na}]^{+} 260.0454$; found 260.0457.

Using p-toluenesulfonyl isocyanate. To a solution of allylic alcohol $\mathbf{1}, \mathbf{5}$ or $17(0.3 \mathrm{mmol})$ in chloroform, dichloromethane or toluene $(0.2 \mathrm{M})$ under argon atmosphere, $p$-toluensulfonylisocyanate $(0.36$ mmol) was added dropwise and the mixture was stirred at room temperature or warmed at $90{ }^{\circ} \mathrm{C}$ during the time indicated in Table 3, Table 4 and Scheme 5. The conversion of the reaction can be followed by ${ }^{1} \mathrm{H}$ NMR using deuterated solvent. The resulting mixture was concentrated in vacuo and the product was purified by flash column chromatography on silica gel to afford the desired product.

1-phenylallyl tosylcarbamate $(\mathbf{1 3 b}) .{ }^{5 \mathrm{c}}$ Prepared from $\mathbf{1 b}(\mathrm{rt}, 5 \mathrm{~min})$ and purified using a hexane/ethyl acetate mixture $\left(80 / 20, R_{f} 0.31\right)$ as eluent. The product was isolated as a colorless oil $(91 \mathrm{mg})$ in $92 \%$ yield. ${ }^{1} \mathrm{H}$ NMR (400 MHz, $\left.\mathrm{CDCl}_{3}\right) \delta 7.88(\mathrm{~d}, J=8.3 \mathrm{~Hz}, 2 \mathrm{H}), 7.55-7.53$ (br s, 1H), 7.34-7.26 (m, 5H), 7.21 (dd, $J=6.8$, $3.0 \mathrm{~Hz}, 2 \mathrm{H}), 6.11(\mathrm{dd}, J=6.0,1.5 \mathrm{~Hz}, 1 \mathrm{H}), 5.92(\mathrm{ddd}, J=16.7,10.5,5.9 \mathrm{~Hz}, 1 \mathrm{H}), 5.27-5.23(\mathrm{~m}, 2 \mathrm{H}), 2.43(\mathrm{~s}$, $3 \mathrm{H}) .{ }^{13} \mathrm{C}\{1 \mathrm{H}\} \mathrm{NMR}\left(101 \mathrm{MHz}, \mathrm{CDCl}_{3}\right) \delta 149.6,145.2,137.5,135.1,129.7,128.7,128.5,127.3,118.2,79.4$, 21.8; HRMS (ESI): $m / z$ calcd. for $\mathrm{C}_{17} \mathrm{H}_{17} \mathrm{NO}_{4} \mathrm{SK}[\mathrm{M}+\mathrm{K}]^{+}: 370.0515$; found: 370.0514 . 
1-(4-chlorophenyl)allyl tosylcarbamate (13c). Prepared from 1c (rt, $5 \mathrm{~min}$ ) and purified using a hexane/ethyl acetate mixture $\left(80 / 20, R_{f} 0.30\right)$ as eluent. The product was isolated as a colorless oil $(93 \mathrm{mg}) \mathrm{in}$ $85 \%$ yield. ${ }^{1} \mathrm{H}$ NMR $\left(400 \mathrm{MHz}, \mathrm{CDCl}_{3}\right) \delta 7.86(\mathrm{~d}, J=8.5 \mathrm{~Hz}, 2 \mathrm{H}), 7.70-7.67$ (br s, 1H), 7.33-7.23 (m, 4H), 7.14 (d, $J=8.5 \mathrm{~Hz}, 2 \mathrm{H}), 6.07$ (d, $J=5.9 \mathrm{~Hz}, 1 \mathrm{H}), 5.87$ (ddd, $J=16.7,10.8,5.9 \mathrm{~Hz}, 1 \mathrm{H}), 5.27-5.23(\mathrm{~m}, 2 \mathrm{H}), 2.44(\mathrm{~s}$, $3 \mathrm{H}) .{ }^{13} \mathrm{C}\{1 \mathrm{H}\} \mathrm{NMR}\left(101 \mathrm{MHz}, \mathrm{CDCl}_{3}\right) \delta 149.6,145.3,136.1,135.6,134.6,129.8,128.9,128.7,128.5,118.6$, 78.5, 21.8. IR $\left(\mathrm{cm}^{-1}\right) 3301,2997,1725,1448,1435,1155,1088,906,728,664,647,547$. HRMS (ESI): $m / z$ calcd. for $\mathrm{C}_{17} \mathrm{H}_{16} \mathrm{ClNO}_{4} \mathrm{SNa}[\mathrm{M}+\mathrm{Na}]^{+}$: 388.0381; found: 388.0380 .

1-(4-nitrophenyl)allyl tosylcarbamate (13d). Prepared from 1d ( $\mathrm{rt}, 5 \mathrm{~min}$ ) and purified using a hexane/ethyl acetate mixture $\left(60 / 40, R_{f} 0.31\right)$ as eluent. The product was isolated as a yellow oil (101 $\left.\mathrm{mg}\right)$ in 90 \% yield. ${ }^{1} \mathrm{H}$ NMR $\left(400 \mathrm{MHz}, \mathrm{CDCl}_{3}\right) \delta 8.14(\mathrm{~d}, J=8.5 \mathrm{~Hz}, 2 \mathrm{H}), 7.88(\mathrm{~d}, J=8.1 \mathrm{~Hz}, 2 \mathrm{H}), 7.37(\mathrm{~d}, J=8.5 \mathrm{~Hz}$, 2H), $7.31(\mathrm{~d}, J=8.1 \mathrm{~Hz}, 2 \mathrm{H}), 6.16(\mathrm{~d}, J=6.1 \mathrm{~Hz}, 1 \mathrm{H}), 5.85(\mathrm{ddd}, J=16.8,10.5,6.1 \mathrm{~Hz}, 1 \mathrm{H}), 5.33-5.24(\mathrm{~m}$, $2 \mathrm{H}), 2.44(\mathrm{~s}, 3 \mathrm{H}) .{ }^{13} \mathrm{C}\{1 \mathrm{H}\} \mathrm{NMR}\left(126 \mathrm{MHz} \mathrm{CDCl}_{3}\right) \delta 149.5,147.9,145.5,144.7,135.5,133.9,129.8,128.4$, 127.8, 123.9, 119.7, 77.9, 21.8. IR ( $\left.\mathrm{cm}^{-1}\right)$ 3236, 3112, 2858, 1748, 1520, 1444, 1345, 1221, 1158, 1098, 853, 665, 548. HRMS (ESI) $m / z$ calcd. for $\mathrm{C}_{17} \mathrm{H}_{20} \mathrm{~N}_{3} \mathrm{O}_{6} \mathrm{~S}\left[\mathrm{M}+\mathrm{NH}_{4}\right]^{+}:$394.1073; found: 394.1070 .

(E)-3-(4-Methoxyphenyl)allyl tosylcarbamate (14a). Prepared from 1a (rt, $15 \mathrm{~min}$.) and purified using a hexane/ethyl acetate mixture $\left(70 / 30, R_{f} 0.23\right)$ as eluent. The product was isolated as a colorless oil $(98 \mathrm{mg}) \mathrm{in}$ $90 \%$ yield. NMR spectra of $\mathbf{1 4 a}$ in $\mathrm{CDCl}_{3}$ at $298 \mathrm{~K}$ revealed the presence of two conformers (rotamers) in a ratio (55/45). ${ }^{1} \mathrm{H}$ NMR (400 MHz, $\left.\mathrm{CDCl}_{3}\right) \delta 7.93(\mathrm{~d}, J=8.5 \mathrm{~Hz}, 1.1 \mathrm{H}), 7.81$ (d, $\left.J=8.6 \mathrm{~Hz}, 0.9 \mathrm{H}\right), 7.37-7.28$ (m, 4H), $6.85(\mathrm{~d}, J=4.7 \mathrm{~Hz}, 2 \mathrm{H}), 6.53(\mathrm{~d}, J=15.9 \mathrm{~Hz}, 1 \mathrm{H}), 6.01(\mathrm{dt}, J=15.9,6.6 \mathrm{~Hz}, 1 \mathrm{H}), 4.77-4.75$ (br s, $1 \mathrm{H}), 4.69$ $(\mathrm{dd}, J=6.6,1.3 \mathrm{~Hz}, 2 \mathrm{H}), 3.81(\mathrm{~s}, 3 \mathrm{H}), 2.43(\mathrm{~s}, 1.65 \mathrm{H}), 2.42(\mathrm{~s}, 1.35 \mathrm{H}) .{ }^{13} \mathrm{C}\{1 \mathrm{H}\} \mathrm{NMR}\left(126 \mathrm{MHz}, \mathrm{CDCl}_{3}\right) \delta$ $159.9,150.6,145.1,143.6,139.2$, 135.6, 135.3, 129.8, 129.7, 128.6, 128.5, 128.1, 126.5, 119.4, 114.2, 67.8, 55.4, 21.8, 21.6. IR (cm $\left.{ }^{-1}\right)$ 3356, 3259, 2959, 1744, 1606, 1510, 1442, 1300, 1245, 1153, 1088, 812, 660, 545, 532. HRMS (ESI): $m / z$ calcd. for $\mathrm{C}_{18} \mathrm{H}_{23} \mathrm{~N}_{2} \mathrm{O}_{5} \mathrm{~S}\left[\mathrm{M}+\mathrm{NH}_{4}\right]^{+}$379.1328; found 379.1324.

(E)-3-(phenyl)allyl tosylcarbamate $(\mathbf{1 4 b}) .{ }^{50}$ Prepared from $\mathbf{1 b}\left(90{ }^{\circ} \mathrm{C}, 6 \mathrm{~h}\right)$ and purified using a hexane/ethyl acetate mixture $\left(60 / 40, R_{f} 0.39\right)$ as eluent. The product was isolated as a white solid $(94 \mathrm{mg})$ in $95 \%$ yield. mp $73-76^{\circ} \mathrm{C}$. NMR spectra of $\mathbf{1 4 b}$ in $\mathrm{CDCl}_{3}$ at $298 \mathrm{~K}$ revealed the presence of two conformers (rotamers) in a ratio $(75 / 25) .{ }^{1} \mathrm{H}$ NMR $\left(400 \mathrm{MHz}, \mathrm{CDCl}_{3}\right) \delta 7.97-7.90(\mathrm{~m}, 1.5 \mathrm{H}), 7.82(\mathrm{~m}, 0.5 \mathrm{H}), 7.37-7.25(\mathrm{~m}, 7 \mathrm{H}), 6.58$ $(\mathrm{d}, J=15.8 \mathrm{~Hz}, 1 \mathrm{H}), 6.14(\mathrm{dt}, J=15.9,6.6 \mathrm{~Hz}, 1 \mathrm{H}), 4.72(\mathrm{dd}, J=6.6,1.3 \mathrm{~Hz}, 2 \mathrm{H}), 2.43(\mathrm{~s}, 0.75 \mathrm{H}), 2.42(\mathrm{~s}$, 2.25H). ${ }^{13} \mathrm{C}\{1 \mathrm{H}\} \operatorname{NMR}\left(126 \mathrm{MHz}, \mathrm{CDCl}_{3}\right): \delta 150.7,145.1,143.5,139.2,135.8,135.5,135.2,129.7,129.6$, 128.7, 128.4, 128.3, 126.7, 126.4, 121.7, 67.3, 21.7, 21.5. HRMS (ESI): $m / z$ calcd. for $\mathrm{C}_{17} \mathrm{H}_{21} \mathrm{~N}_{2} \mathrm{O}_{4} \mathrm{~S}\left[\mathrm{M}+\mathrm{NH}_{4}\right]^{+}$ 349.1222 ; found 349.1222 .

(E)-3-(4-Chlorophenyl)allyl tosylcarbamate $(\mathbf{1 4 c})$. Prepared from $1 \mathrm{c}\left(90{ }^{\circ} \mathrm{C}, 20 \mathrm{~h}\right)$ and purified using a hexane/ethyl acetate mixture $\left(65 / 35, R_{f} 0.26\right)$ as eluent. The product was isolated as a white solid $(77 \mathrm{mg})$ in $70 \%$ yield. mp $86-87^{\circ} \mathrm{C}$. NMR spectra of $14 \mathbf{c}$ in $\mathrm{CDCl}_{3}$ at $298 \mathrm{~K}$ revealed the presence of two conformers (rotamers) in a ratio (60/40). ${ }^{1} \mathrm{H}$ NMR $\left(400 \mathrm{MHz}, \mathrm{CDCl}_{3}\right) \delta 7.93(\mathrm{~d}, J=8.1 \mathrm{~Hz}, 1.2 \mathrm{H}), 7.82(\mathrm{~d}, J=8.1 \mathrm{~Hz}, 0.8 \mathrm{H}), 7.37-$ $7.22(\mathrm{~m}, 6 \mathrm{H}), 6.53(\mathrm{~d}, J=15.9 \mathrm{~Hz}, 1 \mathrm{H}), 6.12(\mathrm{dt}, J=16.0,6.6 \mathrm{~Hz}, 1 \mathrm{H}), 4.83-4.81$ (br s, 1H), $4.71(\mathrm{dd}, J=6.6$, $1.3 \mathrm{~Hz}, 2 \mathrm{H}), 2.43(\mathrm{~s}, 1.8 \mathrm{H}), 2.42(\mathrm{~s}, 1.2 \mathrm{H}) .{ }^{13} \mathrm{C}\{1 \mathrm{H}\} \mathrm{NMR}\left(126 \mathrm{MHz}, \mathrm{CDCl}_{3}\right): \delta 150.6,145.2,143.7,139.2$, 134.4, 134.1, 133.9, 129.8, 129.7, 129.6, 128.9, 128.5, 128.3, 127.9, 126.5, 122.5, 67.1, 21.8. IR (cm' 3355 , 
$3259,3086,2849,1737,1304,1285,1160,1080,969,813,658,583,533$. HRMS (ESI): $\mathrm{m} / z$ calcd. for $\mathrm{C}_{17} \mathrm{H}_{20} \mathrm{ClN}_{2} \mathrm{O}_{4} \mathrm{~S}\left[\mathrm{M}+\mathrm{NH}_{4}\right]^{+}$383.0832; found 383.0829.

(E)-3-(4-Nitrophenyl)allyl tosylcarbamate $(\mathbf{1 4 d})$. Prepared from $1 \mathbf{d}\left(90{ }^{\circ} \mathrm{C}, 4\right.$ days, $70 \%$ conversion) and purified using a hexane/ethyl acetate mixture $\left(80 / 20, R_{f} 0.15\right)$ as eluent. The product was isolated as a yellow oil $\left(45 \mathrm{mg}\right.$ ) in $40 \%$ yield. NMR spectra of $\mathbf{1 4 d}$ in $\mathrm{CDCl}_{3}$ at $298 \mathrm{~K}$ revealed the presence of two conformers (rotamers) in a ratio (99/1). ${ }^{1} \mathrm{H} \mathrm{NMR}\left(400 \mathrm{MHz} \mathrm{CDCl}_{3}\right) \delta 8.18(\mathrm{~d}, J=8.5 \mathrm{~Hz}, 2 \mathrm{H}), 7.94(\mathrm{~d}, J=8.1 \mathrm{~Hz}, 2 \mathrm{H})$, $7.47(\mathrm{~d}, J=8.5 \mathrm{~Hz}, 2 \mathrm{H}), 7.34(\mathrm{~d}, J=8.1 \mathrm{~Hz}, 2 \mathrm{H}), 6.64(\mathrm{~d}, J=16.0 \mathrm{~Hz}, 1 \mathrm{H}), 6.34(\mathrm{dt}, J=16.0,6.2 \mathrm{~Hz}, 1 \mathrm{H}), 4.77$ $(\mathrm{dd}, J=6.2,1.4 \mathrm{~Hz}, 2 \mathrm{H}), 2.43(\mathrm{~s}, 3 \mathrm{H}) .{ }^{13} \mathrm{C}\{1 \mathrm{H}\} \mathrm{NMR}\left(101 \mathrm{MHz}, \mathrm{CDCl}_{3}\right) \delta 145.4,142.3,135.5,132.41,129.8$, 128.6, 127.4, 126.8, 124.2, 66.6, 21.9. IR $\left(\mathrm{cm}^{-1}\right)$ 3450, 2996, 2950, 1723, 1448, 1434, 1272, 1241, 1190, 1148 , 907, 727, 641. HRMS (ESI): $m / z$ calcd. for $\mathrm{C}_{17} \mathrm{H}_{20} \mathrm{~N}_{3} \mathrm{O}_{6} \mathrm{~S}\left[\mathrm{M}+\mathrm{NH}_{4}\right]^{+}:$394.1067; found: 394.1067 .

(E)-3-(4-methylphenyl)allyl tosylcarbamate $(14 e)$. Prepared from $1 \mathrm{e}\left(90{ }^{\circ} \mathrm{C}, 6 \mathrm{~h}\right)$ and purified using a hexane/ethyl acetate mixture $\left(70 / 30, R_{f} 0.26\right)$ as eluent. The product was isolated as a white solid $(72 \mathrm{mg}) \mathrm{in} 70 \%$ yield. mp $82-85{ }^{\circ} \mathrm{C}$. NMR spectra of $14 \mathrm{e}$ in $\mathrm{CDCl}_{3}$ at $298 \mathrm{~K}$ revealed the presence of two conformers (rotamers) in a ratio (65/35). ${ }^{1} \mathrm{H}$ NMR $\left(400 \mathrm{MHz}, \mathrm{CDCl}_{3}\right) \delta 7.93(\mathrm{~d}, J=8.1 \mathrm{~Hz}, 1.3 \mathrm{H}), 7.82(\mathrm{~d}, J=8.1 \mathrm{~Hz}, 0.7 \mathrm{H}), 7.32(\mathrm{~d}, J$ $=7.9 \mathrm{~Hz}, 2 \mathrm{H}), 7.23(\mathrm{~d}, J=8.1 \mathrm{~Hz}, 2 \mathrm{H}), 7.13(\mathrm{~d}, J=7.9 \mathrm{~Hz}, 2 \mathrm{H}), 6.55(\mathrm{~d}, J=15.8 \mathrm{~Hz}, 1 \mathrm{H}), 6.09(\mathrm{dt}, J=15.8,6.7$ $\mathrm{Hz}, 1 \mathrm{H}), 4.73-4.69$ (br s, 1H), 4.71 (dd, $J=6.7,1.2 \mathrm{~Hz}, 2 \mathrm{H}), 2.43$ (s, 1.05H), 2.42 (s, 1.95H), 2.34 (s, 3H). ${ }^{13} \mathrm{C}\{1 \mathrm{H}\} \mathrm{NMR}\left(126 \mathrm{MHz}, \mathrm{CDCl}_{3}\right) \delta 150.7,145.1,143.6,139.2,138.4,135.4,133.1,129.8,129.7,129.4,128.4$, 126.7, 126.5, 120.7, 67.6, 21.7, 21.6, 21.3. IR ( $\left.\mathrm{cm}^{-1}\right)$ 3354, 3229, 3048, 2948, 1754, 1596, 1436, 1344, 1219 , $1147,1088,970,875,665,582,544$. HRMS (ESI): $m / z$ calcd. for $\mathrm{C}_{18} \mathrm{H}_{23} \mathrm{~N}_{2} \mathrm{O}_{4} \mathrm{~S}\left[\mathrm{M}+\mathrm{NH}_{4}\right]^{+} 363.1379$; found 363.1378 .

(E)-3-(4-(benzyloxy)phenyl)allyl tosylcarbamate (14f). Prepared from $1 \mathbf{f}(\mathrm{rt}, 15 \mathrm{~min}$.) and purified using a hexane/ethyl acetate mixture $\left(65 / 35, R_{f} 0.38\right)$ as eluent. The product was isolated as a white solid $(97 \mathrm{mg}) \mathrm{in}$ $74 \%$ yield. mp $106-109{ }^{\circ} \mathrm{C}$. NMR spectra of $\mathbf{1 4 f}$ in $\mathrm{CDCl}_{3}$ at $298 \mathrm{~K}$ revealed the presence of two conformers (rotamers) in a ratio $(65 / 35) .{ }^{1} \mathrm{H}$ NMR $\left(400 \mathrm{MHz}, \mathrm{CDCl}_{3}\right) \delta 7.97-7.88(\mathrm{~d}, J=8.4 \mathrm{~Hz}, 1.3 \mathrm{H}), 7.86-7.78(\mathrm{~d}, J=$ $8.4 \mathrm{~Hz}, 0.7 \mathrm{H}), 7.50-7.25(\mathrm{~m}, 9 \mathrm{H}), 6.97-6.86(\mathrm{~d}, J=8.4 \mathrm{~Hz}, 2 \mathrm{H}), 6.53(\mathrm{~d}, J=15.8 \mathrm{~Hz}, 1 \mathrm{H}), 6.01(\mathrm{dt}, J=15.8$, $6.8 \mathrm{~Hz}, 1 \mathrm{H}), 5.07$ (s, 2H), 4.76-4.73 (br s, 1H), 4.69 (dd, $J=6.9,1.3 \mathrm{~Hz}, 2 \mathrm{H}), 2.43$ (s, 1.05H), $2.42(\mathrm{~s}, 1.95 \mathrm{H})$. ${ }^{13} \mathrm{C}\{1 \mathrm{H}\} \mathrm{NMR}\left(126 \mathrm{MHz}, \mathrm{CDCl}_{3}\right) \delta 159.1,150.6,145.2,143.6,139.2,136.8,135.6,135.2,129.8,129.7,128.9$, $128.7,128.5,128.2,128.1,127.6,126.5,119.6,115.1,70.1,67.7,21.76,21.62$. IR (cm $\left.{ }^{-1}\right) 3356,3250,2950$, 2869, 1738, 1605, 1512, 1433, 1300, 1153, 1064, 813, 660, 530. HRMS (ESI): $m / z$ calcd. for $\mathrm{C}_{24} \mathrm{H}_{27} \mathrm{~N}_{2} \mathrm{O}_{5} \mathrm{~S}$ $\left[\mathrm{M}+\mathrm{NH}_{4}\right]^{+} 455.1641$; found 455.1643 .

(E)-3-(2-methoxyphenyl)allyl tosylcarbamate (14g). Prepared from $1 \mathrm{~g}(\mathrm{rt}, 16 \mathrm{~h})$ and purified using a hexane/ethyl acetate mixture $\left(70 / 30 R_{f} 0.24\right)$ as eluent. The product was isolated as a yellow oil $(92 \mathrm{mg}) \mathrm{in} 85 \%$ yield. NMR spectra of $\mathbf{1 4 g}$ in $\mathrm{CDCl}_{3}$ at $298 \mathrm{~K}$ revealed the presence of two conformers (rotamers) in a ratio (65/35). ${ }^{1} \mathrm{H}$ NMR (400 MHz, $\left.\mathrm{CDCl}_{3}\right) \delta 7.92(\mathrm{~d}, J=8.1 \mathrm{~Hz}, 1.3 \mathrm{H}), 7.81(\mathrm{~d}, J=8.1 \mathrm{~Hz}, 0.7 \mathrm{H}), 7.34-7.22(\mathrm{~m}, 4 \mathrm{H})$, 6.94-6.84 (m, 2H), $6.16(\mathrm{dt}, J=16.0,6.6 \mathrm{~Hz}, 1 \mathrm{H}), 5.25-5.20($ br s, $1 \mathrm{H}), 4.70$ (dd, $J=6.6,1.3 \mathrm{~Hz}, 2 \mathrm{H}), 3.82(\mathrm{~s}$, $3 \mathrm{H}), 2.40(\mathrm{~s}, 1.05 \mathrm{H}), 2.39(\mathrm{~s}, 1.95 \mathrm{H}) .{ }^{13} \mathrm{C}\{1 \mathrm{H}\} \mathrm{NMR}\left(126 \mathrm{MHz}, \mathrm{CDCl}_{3}\right) \delta 157.0,150.6,145.1,143.5,139.3$, 135.6, 130.6, 129.8, 129.7, 129.5, 128.5, 127.3, 126.5, 124.9, 122.3, 120.7, 111.0, 68.0, 55.5, 21.7, 21.6. IR (cm 1) $3355,2946,1744,1596,1488,1437,1343,1242,1152,1067,868,812,751,659,576,544$. HRMS (ESI): $m / z$ calcd. for $\mathrm{C}_{18} \mathrm{H}_{23} \mathrm{~N}_{2} \mathrm{O}_{5} \mathrm{~S}\left[\mathrm{M}+\mathrm{NH}_{4}\right]^{+} 379.1328$; found 379.1325 . 
(E)-3-(2,3-dihydrobenzofuran-5-yl)allyl tosylcarbamate (14h). Prepared from $\mathbf{1 h}(\mathrm{rt}, 1 \mathrm{~h})$ and purified using a hexane/ethyl acetate mixture $\left(60 / 40 R_{f} 0.30\right)$ as eluent. The product was isolated as a colorless oil (40 $\mathrm{mg}$ ) in $36 \%$ yield. NMR spectra of $\mathbf{1 4 h}$ in $\mathrm{CDCl}_{3}$ at $298 \mathrm{~K}$ revealed the presence of two conformers (rotamers) in a ratio (99/1). ${ }^{1} \mathrm{H}$ NMR $\left(400 \mathrm{MHz}, \mathrm{CDCl}_{3}\right) \delta 7.97-7.88(\mathrm{~m}, 2 \mathrm{H}), 7.31(\mathrm{~m}, 2 \mathrm{H}), 7.22-7.19(\mathrm{~m}, 1 \mathrm{H}), 7.07(\mathrm{dd}, J=$ $8.2,1.9 \mathrm{~Hz}, 1 \mathrm{H}), 6.72(\mathrm{~d}, J=8.2 \mathrm{~Hz}, 1 \mathrm{H}), 6.52(\mathrm{~d}, J=15.7 \mathrm{~Hz}, 1 \mathrm{H}), 5.98(\mathrm{dt}, J=15.7,6.8 \mathrm{~Hz}, 1 \mathrm{H}), 4.68(\mathrm{dd}, J=$ 6.8, $1.2 \mathrm{~Hz}, 2 \mathrm{H}), 4.58$ (t, $J=8.7 \mathrm{~Hz}, 2 \mathrm{H}), 3.19$ (t, $J=8.7 \mathrm{~Hz}, 2 \mathrm{H}), 2.42(\mathrm{~s}, 3 \mathrm{H}) .{ }^{13} \mathrm{C}\{1 \mathrm{H}\} \mathrm{NMR}(101 \mathrm{MHz}$, $\left.\mathrm{CDCl}_{3}\right) \delta 160.6,150.5,145.2,135.9,135.6,129.7,128.6,127.5,123.2,118.7,109.5,71.7,67.9,29.6,21.8 . \mathrm{IR}$ $\left(\mathrm{cm}^{-1}\right)$ 3374, 3280, 3054, 1746, 1599, 1491, 1264, 1161, 731, 702, 546. HRMS (ESI): $\mathrm{m} / \mathrm{z}$ calcd. for $\mathrm{C}_{19} \mathrm{H}_{19} \mathrm{NO}_{5} \mathrm{SNa}[\mathrm{M}+\mathrm{Na}]^{+}$396.0882; found 396.0881.

(E)-3-(3,4-dimethoxyphenyl)allyl tosylcarbamate (14i). Prepared from 1i (rt, $45 \mathrm{~min}$.) and purified using a hexane/ethyl acetate mixture $\left(60 / 40 R_{f} 0.20\right)$ as eluent. The product was isolated as a colorless oil $(38 \mathrm{mg}) \mathrm{in}$ $32 \%$ yield. NMR spectra of $\mathbf{1 4} \mathbf{i}$ in $\mathrm{CDCl}_{3}$ at $298 \mathrm{~K}$ revealed the presence of two conformers (rotamers) in a ratio (99/1). ${ }^{1} \mathrm{H}$ NMR (400 MHz, $\left.\mathrm{CDCl}_{3}\right) \delta 7.96-7.89$ (m, 2H), 7.29 (d, $\left.J=8.0 \mathrm{~Hz}, 2 \mathrm{H}\right), 6.90-6.84(\mathrm{~m}, 2 \mathrm{H}), 6.79$ (d, $J$ $=8.1 \mathrm{~Hz}, 1 \mathrm{H}), 6.51(\mathrm{~d}, J=15.8 \mathrm{~Hz}, 1 \mathrm{H}), 6.02(\mathrm{dt}, J=15.8,6.7 \mathrm{~Hz}, 1 \mathrm{H}), 4.69(\mathrm{dd}, J=6.7,0.9 \mathrm{~Hz}, 2 \mathrm{H}), 3.86(\mathrm{~s}$, $6 \mathrm{H}), 2.39(\mathrm{~s}, 3 \mathrm{H}) .{ }^{13} \mathrm{C}\{1 \mathrm{H}\} \mathrm{NMR}\left(126 \mathrm{MHz}, \mathrm{CDCl}_{3}\right) \delta 150.6,149.5,149.1,145.1,135.6,135.5,129.7,128.9$, 128.57, 120.3, 119.7, 111.1, 108.9, 67.6, 56.0, 55.9, 21.7. IR ( $\left.\mathrm{cm}^{-1}\right) 3254,3057,2957,2936,1746,1597,1513$, $1451,1343,1263,1158,1089,1024,732,510$. HRMS (ESI): $m / z$ calcd. for $\mathrm{C}_{19} \mathrm{H}_{25} \mathrm{~N}_{2} \mathrm{O}_{6} \mathrm{~S}\left[\mathrm{M}+\mathrm{NH}_{4}\right]^{+} 409.1433$; found 409.1431 .

(E)-3(3-(benzyloxy)-4-methoxyphenyl)allyl tosylcarbamate (14j). Prepared from $\mathbf{1 j}$ (rt, $45 \mathrm{~min}$.) and purified using a hexane/ethyl acetate mixture $\left(60 / 40 R_{f} 0.33\right)$ as eluent. The product was isolated as a yellow oil $(76 \mathrm{mg})$ in $54 \%$ yield. NMR spectra of $\mathbf{1 4 j}$ in $\mathrm{CDCl}_{3}$ at $298 \mathrm{~K}$ revealed the presence of two conformers (rotamers) in a ratio $(90 / 10) .{ }^{1} \mathrm{H} \mathrm{NMR}\left(400 \mathrm{MHz}, \mathrm{CDCl}_{3}\right) \delta 7.95-7.89(\mathrm{~d}, J=8.3 \mathrm{~Hz}, 1.8 \mathrm{H}), 7.80(\mathrm{~d}, J=8.3 \mathrm{~Hz}$, $0.2 \mathrm{H}), 7.44(\mathrm{~d}, J=7.1 \mathrm{~Hz}, 2 \mathrm{H}), 7.40-7.30(\mathrm{~m}, 5 \mathrm{H}), 6.95-6.83(\mathrm{~m}, 3 \mathrm{H}), 6.47(\mathrm{~d}, J=15.7 \mathrm{~Hz}, 1 \mathrm{H}), 5.95(\mathrm{dt}, J=$ 15.7, $6.7 \mathrm{~Hz}, 1 \mathrm{H}), 5.13(\mathrm{~s}, 2 \mathrm{H}), 4.67(\mathrm{dd}, J=6.7,1.3 \mathrm{~Hz}, 2 \mathrm{H}), 3.88$ (s, 3H), $2.42(\mathrm{~s}, 0.3 \mathrm{H}), 2.40$ (s, $2.7 \mathrm{H})$. ${ }^{13} \mathrm{C}\{1 \mathrm{H}\} \mathrm{NMR}\left(101 \mathrm{MHz}, \mathrm{CDCl}_{3}\right) \delta 150.4,150.3,148.4,145.2,137.1,135.6,129.73,128.90,128.71,128.6$, 128.1, 127.5, 120.8, 119.6, 112.2, 111.8, 71.3, 67.7, 56.2, 21.8. IR (cm $\left.{ }^{-1}\right)$ 3258, 2958, 2930, 1744, 1596, 1510, 1440, 1257, 1155, 1135, 1016, 660, 545. HRMS (ESI): $m / z$ calcd. for $\mathrm{C}_{25} \mathrm{H}_{29} \mathrm{~N}_{2} \mathrm{O}_{6} \mathrm{~S}\left[\mathrm{M}+\mathrm{NH}_{4}\right]^{+} 485.1746$; found 485.1745 .

(E)-3-(benzo[d][1,3]dioxol-5-yl)allyl tosylcarbamate (14k). Prepared from 1k (rt, $3 \mathrm{~h})$ and purified using a hexane/ethyl acetate mixture $\left(65 / 35 R_{f} 0.27\right)$ as eluent. The product was isolated as a white solid (95 $\left.\mathrm{mg}\right)$ in $84 \%$ yield. $\mathrm{mp} 89-91{ }^{\circ} \mathrm{C}$. NMR spectra of $\mathbf{1 4} \mathbf{j}$ in $\mathrm{CDCl}_{3}$ at $298 \mathrm{~K}$ revealed the presence of two conformers (rotamers) in a ratio $(90 / 10) .{ }^{1} \mathrm{H}$ NMR $\left(400 \mathrm{MHz}, \mathrm{CDCl}_{3}\right) \delta 7.92(\mathrm{~d}, J=8.1 \mathrm{~Hz}, 1.6 \mathrm{H}), 7.81(\mathrm{~d}, J=8.1 \mathrm{~Hz}$, $0.4 \mathrm{H}), 7.33-7.29(\mathrm{~m}, 2 \mathrm{H}), 6.84(\mathrm{~s}, 1 \mathrm{H}), 6.75(\mathrm{~d}, J=2.2 \mathrm{~Hz}, 2 \mathrm{H}), 6.47$ (d, $J=15.8 \mathrm{~Hz}, 1 \mathrm{H}), 6.04-5.88$ (m, 3H), 5.05-5.00 (br s, 1H), $4.68(\mathrm{dd}, J=6.9,1.3 \mathrm{~Hz}, 2 \mathrm{H}), 2.41(\mathrm{~s}, 3 \mathrm{H}) .{ }^{13} \mathrm{C}\{1 \mathrm{H}\} \mathrm{NMR}\left(101 \mathrm{MHz}, \mathrm{CDCl}_{3}\right) \delta 150.6$, 148.2 , 147.9, 145.2, 135.6, 135.3, 130.3, 129.7, 128.5, 126.5, 121.8, 119.9, 108.4, 105.9, 101.3, 67.5, 21.7, 21.6. IR $\left(\mathrm{cm}^{-1}\right) 3355,3258,1737,1492,1431,1250,1156,1086,1036,852,810,662,576,549$. HRMS (ESI): $\mathrm{m} / z$ calcd. for $\mathrm{C}_{18} \mathrm{H}_{17} \mathrm{NO}_{6} \mathrm{SNa}[\mathrm{M}+\mathrm{Na}]^{+}$398.0670; found 398.0672.

(2E,4E)-5-(4-methoxyphenyl)penta-2,4-dien-1-yl tosylcarbamate (16a). Prepared from 5a (rt, 30 min.) and purified using a hexane/ethyl acetate mixture $\left(65 / 35 R_{f} 0.24\right)$ as eluent. The product was isolated as a yellow oil $(29 \mathrm{mg})$ in $25 \%$ yield. NMR spectra of $\mathbf{1 6 a}$ in $\mathrm{CDCl}_{3}$ at $298 \mathrm{~K}$ revealed the presence of two conformers 
(rotamers) in a ratio $(75 / 25) .{ }^{1} \mathrm{H}$ NMR $\left(400 \mathrm{MHz}, \mathrm{CDCl}_{3}\right) \delta 7.93(\mathrm{~d}, J=8.2 \mathrm{~Hz}, 1.5 \mathrm{H}), 7.82(\mathrm{~d}, J=8.2 \mathrm{~Hz}$, $0.5 \mathrm{H}), 7.36-7.30(\mathrm{~m}, 4 \mathrm{H}), 6.86(\mathrm{~d}, J=8.7 \mathrm{~Hz}, 2 \mathrm{H}), 6.63-6.52(\mathrm{~m}, 2 \mathrm{H}), 6.36(\mathrm{dd}, J=15.1,9.8 \mathrm{~Hz}, 1 \mathrm{H}), 5.70(\mathrm{dt}$, $J=14.5,6.9 \mathrm{~Hz}, 1 \mathrm{H}), 4.75-4.74($ br s, 1H), 4.63 (d, $J=6.9 \mathrm{~Hz}, 2 \mathrm{H}), 3.81$ (s, 3H), $2.44(\mathrm{~s}, 2.25 \mathrm{H}), 2.41(\mathrm{~s}$, $0.75 \mathrm{H}) .{ }^{13} \mathrm{C}\{1 \mathrm{H}\} \operatorname{NMR}\left(101 \mathrm{MHz}, \mathrm{CDCl}_{3}\right) \delta 159.8,150.4,145.2,136.4,134.4,129.8,128.6,127.9,126.6$, 124.0,114.3, 67.4, 55.5, 21.8, 21.7. IR ( $\left.\mathrm{cm}^{-1}\right)$ 3268, 2957, 2925, 1735, 1601, 1510, 1458, 1341, 1249, 1160, 814, 664, 547. HRMS (ESI): $m / z$ calcd. for $\mathrm{C}_{20} \mathrm{H}_{21} \mathrm{NO}_{5} \mathrm{SNa}[\mathrm{M}+\mathrm{Na}]^{+} 410.1038$; found 410.1036 .

(2E,4E)-5-phenylpenta-2,4-dien-1-yl tosylcarbamate (16b). Prepared from 5b (rt, $4 \mathrm{~h}$ ) and purified using a hexane/ethyl acetate mixture $\left(70 / 30 R_{f} 0.29\right)$ as eluent. The product was isolated as a yellow oil ( $\left.80 \mathrm{mg}\right)$ in $75 \%$ yield. NMR spectra of $\mathbf{1 6} \mathbf{b}$ in $\mathrm{CDCl}_{3}$ at $298 \mathrm{~K}$ revealed the presence of two conformers (rotamers) in a ratio (63/37). ${ }^{1} \mathrm{H}$ NMR (400 $\left.\mathrm{MHz}, \mathrm{CDCl}_{3}\right) \delta$ 7.95-7.91 (m, 1.3H), 7.84-7.80 (m, 0.7H), 7.41-7.36 (m, 2H), 7.36-7.29 (m, 4H), 7.27-7.24 (m, 1H), $6.71(\mathrm{dd}, J=15.7,10.3 \mathrm{~Hz}, 1 \mathrm{H}), 6.56(\mathrm{~d}, J=15.7 \mathrm{~Hz}, 1 \mathrm{H}), 6.37$ (dd, $J=$ 15.2, $10.4 \mathrm{~Hz}, 1 \mathrm{H}), 5.75$ (dt, $J=14.1,6.7 \mathrm{~Hz}, 1 \mathrm{H}), 5.02-4.93$ (br s, 1H), 4.64 (d, $J=6.7 \mathrm{~Hz}, 2 \mathrm{H}), 2.43$ (s, $1.9 \mathrm{H})$, $2.42(\mathrm{~s}, 1.1 \mathrm{H}) .{ }^{13} \mathrm{C}\{1 \mathrm{H}\} \mathrm{NMR}\left(126 \mathrm{MHz}, \mathrm{CDCl}_{3}\right) \delta 150.6,145.2,143.6,139.2,136.8,135.6,134.5,129.8$, 128.7, 128.4, 128.1, 127.4, 126.6, 126.5, 125.4, 67.1, 21.7, 21.6. IR (cm-1) 3355, 3259, 1745, 1441, 1302, 1152 , 660, 544. HRMS (ESI): $m / z$ calcd. for $\mathrm{C}_{19} \mathrm{H}_{19} \mathrm{NO}_{4} \mathrm{SNa}[\mathrm{M}+\mathrm{Na}]^{+} 380.0932$; found 380.0929 .

(2E,4E)-5-(4-chlorophenyl)penta-2,4-dien-1-yl tosylcarbamate (16c). Prepared from 5c (rt, $4 \mathrm{~h})$ and purified using a hexane/ethyl acetate mixture $\left(70 / 30 R_{f} 0.22\right)$ as eluent. The product was isolated as pale yellow oil $\left(80 \mathrm{mg}\right.$ ) in $68 \%$ yield. NMR spectra of $\mathbf{1 6 c}$ in $\mathrm{CDCl}_{3}$ at $298 \mathrm{~K}$ revealed the presence of two conformers (rotamers) in a ratio $(75 / 25) .{ }^{1} \mathrm{H}$ NMR $\left(400 \mathrm{MHz}, \mathrm{CDCl}_{3}\right) \delta 7.96-7.88(\mathrm{~m}, 1.5 \mathrm{H}), 7.85-7.76(\mathrm{~m}, 0.5 \mathrm{H}), 7.31(\mathrm{~d}, J$ $=8.1 \mathrm{~Hz}, 2 \mathrm{H}), 7.29-7.22(\mathrm{~m}, 4 \mathrm{H}), 6.64(\mathrm{dd}, J=15.7,10.5 \mathrm{~Hz}, 1 \mathrm{H}), 6.46(\mathrm{~d}, J=15.7 \mathrm{~Hz}, 1 \mathrm{H}), 6.33(\mathrm{dd}, J=15.2$, $10.4 \mathrm{~Hz}, 1 \mathrm{H}), 5.75(\mathrm{dt}, J=15.2,6.5 \mathrm{~Hz}, 1 \mathrm{H}), 4.62(\mathrm{~d}, J=6.5 \mathrm{~Hz}, 2 \mathrm{H}), 2.40(\mathrm{~s}, 2.25 \mathrm{H}), 2.39(\mathrm{~s}, 0.75 \mathrm{H}) .{ }^{13} \mathrm{C}\{1 \mathrm{H}\}$ NMR $\left(126 \mathrm{MHz}, \mathrm{CDCl}_{3}\right) \delta 150.5,145.2,143.7,139.2,135.5,135.2,133.7,133.1,129.8,129.7,128.9,128.5$, 127.9, 127.8, 126.5, 125.9, 67.0, 21.8, 21.6. IR ( $\left.\mathrm{cm}^{-1}\right)$ 3272, 3055, 1749, 1595, 1344, 1264, 1159, 1089, 732, 510. HRMS (ESI): $m / z$ calcd. for $\mathrm{C}_{19} \mathrm{H}_{18} \mathrm{ClNO}_{4} \mathrm{SNa}[\mathrm{M}+\mathrm{Na}]^{+} 414.0543$; found 414.0542 .

(2E,4E)-5-(4-nitrophenyl)penta-2,4-dien-1-yl tosylcarbamate (16d). Prepared from $\mathbf{5 d}\left(90{ }^{\circ} \mathrm{C}, 5\right.$ days) and purified using a hexane/ethyl acetate mixture $\left(60 / 40 R_{f} 0.26\right)$ as eluent. The product was isolated as an orange oil (44 mg) in $36 \%$ yield. NMR spectra of $\mathbf{1 6 d}$ in $\mathrm{CDCl}_{3}$ at $298 \mathrm{~K}$ revealed the presence of two conformers (rotamers) in a ratio (99/1). ${ }^{1} \mathrm{H}$ NMR $\left(400 \mathrm{MHz}, \mathrm{CDCl}_{3}\right) \delta 8.18(\mathrm{~d}, J=8.5 \mathrm{~Hz}, 2 \mathrm{H}), 7.93(\mathrm{~d}, J=8.1$ $\mathrm{Hz}, 2 \mathrm{H}), 7.50$ (d, $J=8.5 \mathrm{~Hz}, 2 \mathrm{H}), 7.35$ (d, $J=8.1 \mathrm{~Hz}, 2 \mathrm{H}), 6.85(\mathrm{dd}, J=15.7,10.5 \mathrm{~Hz}, 1 \mathrm{H}), 6.60(\mathrm{~d}, J=15.7$ $\mathrm{Hz}, 1 \mathrm{H}), 6.41$ (dd, $J=15.3,10.6 \mathrm{~Hz}, 1 \mathrm{H}), 5.90$ (dt, $J=15.3,5.9 \mathrm{~Hz}, 1 \mathrm{H}), 4.67$ (d, $J=5.9 \mathrm{~Hz}, 2 \mathrm{H}), 2.44$ (s, 3H). ${ }^{13} \mathrm{C}\{1 \mathrm{H}\} \mathrm{NMR}\left(101 \mathrm{MHz}, \mathrm{CDCl}_{3}\right) \delta 150.3,147.1,145.4,143.3,135.5,134.3,131.9,129.8,128.7,128.5,127.1$, 124.2, 66.6, 21.8. IR (cm-1) 3237, 2957, 2927, 1749, 1594, 1514, 1450, 1340, 1158, 1089, 860, 662, $577,547$. HRMS (ESI): $m / z$ calcd. for $\mathrm{C}_{19} \mathrm{H}_{18} \mathrm{~N}_{2} \mathrm{O}_{6} \mathrm{SNa}[\mathrm{M}+\mathrm{Na}]^{+} 425.0783$; found 425.0785 .

(3E,5E)-6-(4-Chlorophenyl)hexa-3,5-dien-2-yl tosylcarbamate (18ba). Prepared from 17b (rt, $2 \mathrm{~h})$. The compound is unstable on silica gel but a pure sample can be obtained by flash chromatography using a cyclohexane/ethyl acetate mixture $\left(70 / 30 R_{f} 0.28\right)$ as eluent. The product was isolated as a yellow oil. ${ }^{1} \mathrm{H}$ NMR $\left(300 \mathrm{MHz}, \mathrm{CD}_{2} \mathrm{Cl}_{2}\right) \delta 7.90(\mathrm{~d}, J=8.4 \mathrm{~Hz}, 2 \mathrm{H}), 7.80-7.77$ (br s, 1H), 7.38-7.34 (m, 2H), 7.36-7.25 (m, 4H), 6.75-6.63 (m, 1H), $6.51(\mathrm{~d}, J=15.7 \mathrm{~Hz}, 1 \mathrm{H}), 6.32(\mathrm{ddd}, J=15.2,10.3,1.1 \mathrm{~Hz}, 1 \mathrm{H}), 5.71(\mathrm{dd}, J=15.2,6.8 \mathrm{~Hz}$, $1 \mathrm{H}), 5.36-5.24(\mathrm{~m}, 1 \mathrm{H}), 2.43(\mathrm{~s}, 3 \mathrm{H}), 1.32(\mathrm{~d}, J=6.5 \mathrm{~Hz}, 3 \mathrm{H}) .{ }^{13} \mathrm{C}\{1 \mathrm{H}\} \mathrm{NMR}\left(75 \mathrm{MHz}, \mathrm{CD}_{2} \mathrm{Cl}_{2}\right) \delta 149.8,145.3$, $135.6,135.5,133.2,132.5,132.2,131.9,129.6,128.7,128.3,128.2,127.6,126.3,74.1,21.4,19.9$. IR $\left(\mathrm{cm}^{-1}\right)$ 
$3227,1740,1596,1490,1436,1344,1222,1157,1088,986,813,767,660$. HRMS (ESI): $\mathrm{m} / z$ calcd. for $\mathrm{C}_{20} \mathrm{H}_{19} \mathrm{ClNO}_{4} \mathrm{~S}[\mathrm{M}-\mathrm{H}]^{-}$404.0729; found 404.0729.

Using phenyl and isopropyl isocyanate. To a solution of allylic alcohol 1a $(0.7 \mathrm{mmol})$ in dry dichloromethane $(0.35 \mathrm{M})$ were added the desired isocyanate $(1.05 \mathrm{mmol}, 1.5 \mathrm{eq}), \mathrm{Et}_{3} \mathrm{~N}(1.05 \mathrm{mmol}, 1.5 \mathrm{eq})$ and DMAP (0.04 mmol, $5 \mathrm{~mol} \%)$. The reaction was stirred at reflux for 16 hours. Dichloromethane was evaporated and the crude product was purified by silica gel chromatography to afford the branched carbamate.

1-(4-Methoxyphenyl)allyl phenylcarbamate (11). Prepared from phenyl isocyanate and purified using a cyclohexane/ethyl acetate mixture $\left(80 / 20, R_{f} 0.28\right)$ as eluent. The product was isolated as a colorless oil (53 mg) in 30\% yield. ${ }^{1} \mathrm{H}$ NMR $\left(300 \mathrm{MHz}, \mathrm{CDCl}_{3}\right) \delta 7.43-7.26(\mathrm{~m}, 6 \mathrm{H}), 7.11-7.05(\mathrm{~m}, 1 \mathrm{H}), 6.93(\mathrm{~d}, J=8.7 \mathrm{~Hz}, 2 \mathrm{H})$, 6.87-6.83 (br s, 1H), 6.28 (d, $J=5.7 \mathrm{~Hz}, 1 \mathrm{H}), 6.10$ (ddd, $J=17.2,10.4,5.6 \mathrm{~Hz}, 1 \mathrm{H}), 5.42-5.26(\mathrm{~m}, 2 \mathrm{H}), 3.83$ (s, $3 \mathrm{H}) .{ }^{13} \mathrm{C}\{1 \mathrm{H}\} \mathrm{NMR}\left(101 \mathrm{MHz}\right.$, Acetone- $\left.d_{6}\right) \delta 160.5,153.5,140.1,138.1,132.4,129.6,129.4,123.4,119.1$, 116.2, 114.6, 76.7, 55.5. IR (cm-1) 3325, 2934, 2482, 1704, 1601, 1501, 1402, 1242, 1174, 1027, 827, $750,691$. HRMS (ESI) $m / z$ calcd. for $\mathrm{C}_{17} \mathrm{H}_{17} \mathrm{NO}_{3} \mathrm{Na}[\mathrm{M}+\mathrm{Na}]^{+}$306.1101; found 306.1099.

1-(4-Methoxyphenyl)allyl isopropylcarbamate (12). Prepared from isopropyl isocyanate and purified using a cyclohexane/ethyl acetate mixture $\left(90 / 10, R_{f} 0.18\right)$ as eluent. The product was isolated as a yellow solid $(62 \mathrm{mg})$ in $65 \%$ yield. m.p. $120-123{ }^{\circ} \mathrm{C} .{ }^{1} \mathrm{H}$ NMR $\left(300 \mathrm{MHz}, \mathrm{CDCl}_{3}\right) \delta 7.28(\mathrm{~d}, J=8.7 \mathrm{~Hz}, 2 \mathrm{H}), 6.88(\mathrm{~d}, J=8.7$ $\mathrm{Hz}, 2 \mathrm{H}), 6.13$ (d, $J=5.7 \mathrm{~Hz}, 1 \mathrm{H}), 6.01$ (ddd, $J=17.1,10.4,5.6 \mathrm{~Hz}, 1 \mathrm{H}), 5.34-5.11$ (m, 2H), 4.60-4.55 (br s, $1 \mathrm{H}), 3.88-3.80(\mathrm{~m}, 1 \mathrm{H}), 3.80(\mathrm{~s}, 3 \mathrm{H}), 1.14(\mathrm{dd}, J=8.7,6.4 \mathrm{~Hz}, 6 \mathrm{H}) .{ }^{13} \mathrm{C}\{1 \mathrm{H}\} \mathrm{NMR}\left(75 \mathrm{MHz}, \mathrm{CDCl}_{3}\right) \delta 159.5$, 154.9, 137.1, 131.7, 128.7, 116.1, 114.0, 113.6, 76.0, 55.3, 23.1. IR ( $\left.\mathrm{cm}^{-1}\right) 3329,2972,1685,1612,1523,1512$, $1242,1175,1070,1031,926,828,816,778$. HRMS (ESI) $m / z$ calcd. for $\mathrm{C}_{14} \mathrm{H}_{19} \mathrm{NO}_{3} \mathrm{Na}[\mathrm{M}+\mathrm{Na}]^{+} 272.1257$; found 272.1254 .

Using benzoyl isocyanate. To a solution of allylic alcohol $1 \mathrm{a}$ or $17(0.7 \mathrm{mmol})$ in dry $\mathrm{CH}_{2} \mathrm{Cl}_{2}$ or $\mathrm{CDCl}_{3}$ $(0.70 \mathrm{M})$ was added the desired isocyanate $(0.84 \mathrm{mmol}, 1.2 \mathrm{eq})$. The reaction was stirred at room temperature for desired time (Scheme 4 and Scheme 5). Solvent was evaporated and the crude product was purified by silica gel chromatography to afford the desired compound.

(E)-3-(4-Methoxyphenyl)allyl benzoylcarbamate (15). Prepared from 1a in $30 \mathrm{~min}$. and purified using a cyclohexane/ethyl acetate mixture $\left(70 / 30, R_{f} 0.31\right)$ as eluent. The product was isolated as a colorless oil (137 mg) in $63 \%$ yield. ${ }^{1} \mathrm{H}$ NMR $\left(400 \mathrm{MHz}, \mathrm{CDCl}_{3}\right) \delta 8.57-8.53($ br s, $1 \mathrm{H}), 7.81(\mathrm{~d}, J=7.2 \mathrm{~Hz}, 2 \mathrm{H}), 7.53-7.47(\mathrm{~m}, 1 \mathrm{H})$, $7.39(\mathrm{dd}, J=8.3,7.1 \mathrm{~Hz}, 2 \mathrm{H}), 7.23(\mathrm{~d}, J=8.8 \mathrm{~Hz}, 2 \mathrm{H}), 6.79$ (d, $J=8.8 \mathrm{~Hz}, 2 \mathrm{H}), 6.56(\mathrm{~d}, J=15.8 \mathrm{~Hz}, 1 \mathrm{H}), 6.09$ $(\mathrm{dt}, J=15.9,6.8 \mathrm{~Hz}, 1 \mathrm{H}), 4.75(\mathrm{dd}, J=6.8,1.2 \mathrm{~Hz}, 2 \mathrm{H}), 3.74(\mathrm{~s}, 3 \mathrm{H}) .{ }^{13} \mathrm{C}\{1 \mathrm{H}\} \mathrm{NMR}\left(101 \mathrm{MHz}, \mathrm{CDCl}_{3}\right) \delta$ $165.2,159.8,151.2,135.2,133.0,132.9,130.6,128.8,128.7,128.0,127.8,119.9,114.1,67.7,67.0$, 55.3. IR $\left(\mathrm{cm}^{-1}\right)$ 3241, 3189, 3035, 3008, 2835, 1747, 1683, 1606, 1507, 1488, 1192, 1173, 1054, 1033, 1025, 969, 834, 778, 701. HRMS (ESI) $m / z$ calcd. for $\mathrm{C}_{18} \mathrm{H}_{17} \mathrm{NO}_{4} \mathrm{Na}[\mathrm{M}+\mathrm{Na}]^{+} 334.1050$; found 334.1050.

(3E,5E)-6-Phenylhexa-3,5-dien-2-yl benzoylcarbamate (18ab). Prepared from 17a (rt, $2 \mathrm{~h})$. The compound is unstable on silica gel but a pure sample can be obtained by flash chromatography using a cyclohexane/ethyl acetate mixture $\left(70 / 30, R_{f} 0.24\right)$ as eluent. The product was isolated as a slight yellow oil. ${ }^{1} \mathrm{H}$ NMR (300 MHz, $\left.\mathrm{CDCl}_{3}\right) \delta 8.02-7.59$ (br s, 1H), 7.87-7.77 (m, 2H), 7.62-7.54 (m, 1H), 7.52-7.45 (m, 3H), $7.45-7.33(\mathrm{~m}, 2 \mathrm{H}), 7.35-7.28(\mathrm{~m}, 2 \mathrm{H}), 6.74(\mathrm{dd}, J=15.6,10.2 \mathrm{~Hz}, 1 \mathrm{H}), 6.61(\mathrm{~d}, J=15.7 \mathrm{~Hz}, 1 \mathrm{H}), 6.50(\mathrm{dd}, J=$ 15.1, $9.8 \mathrm{~Hz}, 1 \mathrm{H}), 5.82(\mathrm{dd}, J=15.1,7.0 \mathrm{~Hz}, 1 \mathrm{H}), 5.54(\mathrm{~m}, 1 \mathrm{H}), 1.47(\mathrm{~d}, J=6.5 \mathrm{~Hz}, 3 \mathrm{H}) .{ }^{13} \mathrm{C}\{1 \mathrm{H}\} \mathrm{NMR}(75$ $\mathrm{MHz}_{\mathrm{CDCl}} \mathrm{CD} \delta 165.3,151.4,150.6,134.2,133.2,133.0,132.9,132.0,128.8,128.6,128.5,128.3,127.9,127.7$, 
127.5, 126.5, 73.3, 20.3. IR $\left(\mathrm{cm}^{-1}\right) 3285,3028,2984,1754,1665,1510,1488,1192,1035,989$, 690. HRMS (ESI) $m / z$ calcd. for $\mathrm{C}_{20} \mathrm{H}_{19} \mathrm{NO}_{3} \mathrm{Na}[\mathrm{M}+\mathrm{Na}]^{+} 344.1257$; found 344.1257.

(3E,5E)-6-(4-Chlorophenyl)hexa-3,5-dien-2-yl benzoylcarbamate (18bb). Prepared from 17b (rt, 2 h). The compound is unstable on silica gel but a pure sample can be obtained by flash chromatography using a cyclohexane/ethyl acetate mixture $\left(70 / 30, R_{f} 0.34\right)$ as eluent. The product was isolated as a yellow oil. ${ }^{1} \mathrm{H}$ NMR (300 MHz, $\left.\mathrm{CD}_{2} \mathrm{Cl}_{2}\right) \delta 8.32-8.30$ (br s, 1H), 7.86-7.80 (m, 2H), 7.64-7.55 (m, 1H), 7.53-7.45 (m, 2H), 7.39-7.25 $(\mathrm{m}, 4 \mathrm{H}), 6.75(\mathrm{dd}, J=15.4,10.6 \mathrm{~Hz}, 1 \mathrm{H}), 6.56(\mathrm{~d}, J=15.7 \mathrm{~Hz}, 1 \mathrm{H}), 6.48(\mathrm{ddd}, J=15.2,10.4,1.1 \mathrm{~Hz}, 1 \mathrm{H}), 5.86$ $(\mathrm{dd}, J=15.2,6.8 \mathrm{~Hz}, 1 \mathrm{H}), 5.49(\mathrm{~m}, 1 \mathrm{H}), 1.44(\mathrm{~d}, J=6.5 \mathrm{~Hz}, 3 \mathrm{H}) .{ }^{13} \mathrm{C}\{1 \mathrm{H}\} \operatorname{NMR}\left(75 \mathrm{MHz}, \mathrm{CD}_{2} \mathrm{Cl}_{2}\right) \delta 164.8$, $150.1,135.6,133.3,133.2,132.9,132.5,132.4,132.2,128.8,128.7,128.5,128.4,127.7,127.5,127.3,72.9$, 20.0. IR $\left(\mathrm{cm}^{-1}\right) 3252,2982,2930,1742,1683,1519,1488,1288,1202,1121,1088,992,830,776,703$. HRMS (ESI) $m / z$ calcd. for $\mathrm{C}_{20} \mathrm{H}_{18} \mathrm{ClNO}_{3}[\mathrm{M}-\mathrm{H}]^{-}$354.0902; found 354.0902.

\section{Using $(R)-(+)-(4-f l u o r o p h e n y l) e t h y l$ isocyanate.}

(S,E)-4-phenylbut-3-en-2-yl ((R)-1-(4-fluorophenyl)ethyl)carbamate (22). To a solution of (+)-(S,E)-1phenylbut-2-enol 20 (ee 98\%, $0.15 \mathrm{mmol})$ in toluene $(0.2 \mathrm{M})$ under argon atmosphere, $(R)-(+)-(4-$ fluorophenyl)ethyl isocyanate $19(0.17 \mathrm{mmol})$ and triethylamine $(0.05 \mathrm{mmol})$ were added and the mixture was stirred at $90{ }^{\circ} \mathrm{C}$ for $6 \mathrm{~h}$. The initial mixture was concentrated in vacuo, diluted with $\mathrm{Et}_{2} \mathrm{O}(2 \mathrm{~mL})$ and washed with saturated $\mathrm{NaCl}(3 \times 2 \mathrm{~mL})$. The resulting crude mixture was diluted in toluene $(0.2 \mathrm{M})$ and stirred at $110^{\circ} \mathrm{C}$ for 48 h. The final mixture was purified by flash column chromatography on neutral aluminium oxide using a hexane/ethyl acetate mixture $\left(83 / 17, R_{f} 0.64\right)$ as eluent. The product was isolated as a colorless oil $(19 \mathrm{mg}) \mathrm{in}$ $39 \%$ yield. ${ }^{1} \mathrm{H}$ NMR $\left(400 \mathrm{MHz}, \mathrm{CDCl}_{3}\right) \delta 7.39-7.26(\mathrm{~m}, 7 \mathrm{H}), 7.00(\mathrm{dd}, J=8.6,8.6 \mathrm{~Hz}, 2 \mathrm{H}), 6.56(\mathrm{~d}, J=16.0$ $\mathrm{Hz}, 1 \mathrm{H}), 6.17$ (dd, $J=16.0,6.5 \mathrm{~Hz}, 1 \mathrm{H}), 5.41$ (dd, $J=6.5,6.5 \mathrm{~Hz}, 1 \mathrm{H}), 4.92-4.90$ (br s, 1H), 4.86-4.78 (m, 1H), $1.50-1.45(\mathrm{~m}, 3 \mathrm{H}), 1.43-1.36(\mathrm{~m}, 3 \mathrm{H}) .{ }^{13} \mathrm{C}\{1 \mathrm{H}\} \mathrm{NMR}\left(101 \mathrm{MHz}, \mathrm{CDCl}_{3}\right) \delta 162.08\left(\mathrm{~d},{ }^{1} J_{C F}=244.9 \mathrm{~Hz}\right), 155.21$, 136.56, 131.24, 129.38, 128.68, 127.97, $127.68\left(\mathrm{~d},{ }^{3} J_{C F}=8.3 \mathrm{~Hz}\right), 126.68,115.53\left(\mathrm{~d},{ }^{2} J_{C F}=21.1 \mathrm{~Hz}\right), 71.66$, 50.15, 22.68, 20.75; ${ }^{19} \mathrm{~F}$ NMR (376 MHz, $\left.\mathrm{CDCl}_{3}\right) \delta$-115.58. IR $\left(\mathrm{cm}^{-1}\right)$ 3343, 2979, 2931, 1680, 1529, 1508, 1221, 1058, 548. HRMS (ESI) $m / z$ calcd. for $\mathrm{C}_{19} \mathrm{H}_{20} \mathrm{FNO}_{2} \mathrm{Na}[\mathrm{M}+\mathrm{Na}]^{+}$336.1376; found 336.1371. HPLC (ChiralPak IB, hexane/iPrOH = 97:3, flow rate $1 \mathrm{~mL} / \mathrm{min}, \lambda 210 \mathrm{~nm}$ ), $t_{R}$ (minor) $13.64 \mathrm{~min}, t_{R}$ (major) $15.71 \mathrm{~min}$; $95 \%$ de. $[\alpha]^{22}=-15.91\left(\right.$ c $\left.0.35, \mathrm{CHCl}_{3}\right)$.

\section{General procedure for the synthesis of allylamine derivatives 8, 9 and 10 via an}

\section{allyl cyanate/isocyanate rearrangement from $4 a$.}

To a solution of carbamate $4 \mathbf{a}(0.25 \mathrm{mmol})$ in dry dichloromethane $(0.13 \mathrm{M})$ cooled at $0{ }^{\circ} \mathrm{C}$ under argon atmosphere was added TFAA $(0.75 \mathrm{mmol})$ and triethylamine $(1.13 \mathrm{mmol})$. The reaction mixture was stirred at $0^{\circ} \mathrm{C}$ for 1 hour and then the desired nucleophile $(0.38 \mathrm{mmol})$, and $\mathrm{Ti}(\mathrm{O} t-\mathrm{Bu})_{4}(0.025 \mathrm{mmol})$ if necessary, were added at $0{ }^{\circ} \mathrm{C}$. The reaction mixture was stirred at room temperature during the required time (Scheme 2). Water was added and the aqueous layer was extracted three times with $\mathrm{CH}_{2} \mathrm{Cl}_{2}$. The collected organic layers were dried over $\mathrm{MgSO}_{4}$, filtered and concentrated under vacuo. The crude product was purified by silica gel chromatography.

1,1-Diethyl-3-(1-(4-methoxyphenyl)allyl)urea (8). Prepared using $\mathrm{HNEt}_{2}$ as nucleophile and purified using a cyclohexane/ethyl acetate mixture $\left(70 / 30, R_{f} 0.51\right)$ as eluent. The product was isolated as a colorless oil $(33 \mathrm{mg})$ in 50\% yield. ${ }^{1} \mathrm{H}$ NMR $\left(400 \mathrm{MHz}, \mathrm{CDCl}_{3}\right) \delta 7.24(\mathrm{~d}, J=8.6 \mathrm{~Hz}, 2 \mathrm{H}), 6.87(\mathrm{~d}, J=8.6 \mathrm{~Hz}, 2 \mathrm{H}), 6.04$ 
(ddd, $J=16.8,10.6,5.2 \mathrm{~Hz}, 1 \mathrm{H}), 5.50$ (dddd, $J=7.2,5.2,1.7,1.7 \mathrm{~Hz}, 1 \mathrm{H}), 5.24-5.14(\mathrm{~m}, 2 \mathrm{H}), 4.52(\mathrm{~d}, J=7.6$ $\mathrm{Hz}, 1 \mathrm{H}), 3.79$ (s, 3H), 3.27 (q, $J=7.4 \mathrm{~Hz}, 4 \mathrm{H}), 1.14(\mathrm{t}, J=7.4 \mathrm{~Hz}, 6 \mathrm{H}) .{ }^{13} \mathrm{C}\{1 \mathrm{H}\} \mathrm{NMR}\left(101 \mathrm{MHz}^{\mathrm{CDCl}}\right)_{3} \delta$ 159.0, 156.5, 139.1, 134.2, 128.5, 115.0, 114.1, 55.8, 55.4, 41.4, 14.1. IR (cm-1) 3348, 2977, 2931, 1618, 1510, 1249, 1177, 1031, 908, 828, 810, 762. HRMS (ESI) $\mathrm{m} / z$ calcd. for $\mathrm{C}_{15} \mathrm{H}_{22} \mathrm{~N}_{2} \mathrm{O}_{2} \mathrm{Na}[\mathrm{M}+\mathrm{Na}]^{+}$285.1574; found 285.1574.

1-Allyl-1-benzyl-3-(1-(4-methoxyphenyl)allyl)urea (9). Prepared using $N$-benzyl allylamine as nucleophile and purified using a cyclohexane/ethyl acetate mixture $\left(70 / 30, R_{f} 0.54\right)$ as eluent. The product was isolated as a colorless oil (46 mg) in 55\% yield. ${ }^{1} \mathrm{H} \mathrm{NMR}\left(400 \mathrm{MHz}, \mathrm{CDCl}_{3}\right) \delta 7.36-7.27(\mathrm{~m}, 2 \mathrm{H}), 7.28-7.23(\mathrm{~m}$, $3 \mathrm{H}), 7.12(\mathrm{~d}, J=8.6 \mathrm{~Hz}, 2 \mathrm{H}), 6.83(\mathrm{~d}, J=8.6 \mathrm{~Hz}, 2 \mathrm{H}), 5.95(\mathrm{ddd}, J=17.2,10.4,5.2 \mathrm{~Hz}, 1 \mathrm{H}), 5.78$ (ddt, $J=17.5$, 9.9, $5.5 \mathrm{~Hz}, 1 \mathrm{H}), 5.52-5.45(\mathrm{~m}, 1 \mathrm{H}), 5.20-5.15(\mathrm{~m}, 2 \mathrm{H}), 5.13-5.04(\mathrm{~m}, 2 \mathrm{H}), 4.73(\mathrm{~d}, J=7.8 \mathrm{~Hz}, 1 \mathrm{H}), 4.57-4.40$ $(\mathrm{m}, 2 \mathrm{H}), 3.88(\mathrm{dd}, J=5.5,1.6 \mathrm{~Hz}, 2 \mathrm{H}), 3.78(\mathrm{~s}, 3 \mathrm{H}) .{ }^{13} \mathrm{C}\{1 \mathrm{H}\} \mathrm{NMR}\left(101 \mathrm{MHz}, \mathrm{CDCl}_{3},\right) \delta 158.9,157.5,138.9$, 138.1, 134.1, 133.9, 128.8, 128.3, 127.5, 117.1, 114.8, 114.0, 56.0, 55.4, 50.5, 49.9. IR (cm $\left.{ }^{-1}\right) 3316,2960,2917$, $2849,1613,1531,1511,1240,1176,1028,927,803$, 702. HRMS (ESI) $m / z$ calcd. for $\mathrm{C}_{21} \mathrm{H}_{24} \mathrm{~N}_{2} \mathrm{O}_{2} \mathrm{Na}[\mathrm{M}+\mathrm{Na}]^{+}$ 359.1730; found 359.1729 .

Benzyl (1-(4-methoxyphenyl)allyl)carbamate (10). ${ }^{51}$ Prepared using benzyl alcohol as nucleophile and purified using a cyclohexane/ethyl acetate mixture $\left(80 / 20, R_{f} 0.50\right)$ as eluent. The product was isolated as a colorless oil (33 mg) in 45\% yield. ${ }^{1} \mathrm{H}$ NMR $\left(300 \mathrm{MHz}, \mathrm{CDCl}_{3}\right) \delta 7.37-7.32(\mathrm{~m}, 5 \mathrm{H}), 7.21(\mathrm{~d}, J=8.3 \mathrm{~Hz}, 2 \mathrm{H})$, $6.83(\mathrm{~d}, J=8.3 \mathrm{~Hz}, 2 \mathrm{H}), 6.00(\mathrm{ddd}, J=17.4,10.1,5.2 \mathrm{~Hz}, 1 \mathrm{H}), 5.34-5.07(\mathrm{~m}, 6 \mathrm{H}), 3.80(\mathrm{~s}, 3 \mathrm{H}) .{ }^{13} \mathrm{C}\{1 \mathrm{H}\} \mathrm{NMR}$ $\left(75 \mathrm{MHz}, \mathrm{CDCl}_{3}\right) \delta 159.2,155.6,137.9,136.5,132.9,128.6,128.4,128.2,115.6,114.2,67.0,55.4$.

\section{Preparation of $\left[{ }^{17} \mathrm{O}\right]$ labelled compounds.}

$\left[{ }^{17} \mathrm{O}_{2}\right]$ benzoic acid $\left.\left(\boldsymbol{I}^{17} \boldsymbol{O}_{2}\right] 25\right) .{ }^{30}$ (Trichloromethyl)benzene $(1.75 \mathrm{mmol})$ and $0.59 \mathrm{~mL}$ of $\mathrm{H}_{2}{ }^{17} \mathrm{O}$ were placed in a microwave vessel and sealed. The resulting mixture was irradiated with microwaves at $150 \mathrm{~W}, 130$ ${ }^{\circ} \mathrm{C}$ and 6 bar for 30 minutes. Once the mixture was cooled down to room temperature, the solid formed was filtered and washed with hexane. The desired pure compound was obtained as a white solid (200 $\mathrm{mg})$ in $93 \%$ yield. ${ }^{1} \mathrm{H}$ NMR (400 MHz, Acetone- $\left.d_{6}\right): \delta 8.07-8.02(\mathrm{~m}, 2 \mathrm{H}), 7.66-7.60(\mathrm{~m}, 1 \mathrm{H}), 7.51(\mathrm{dd}, J=8.4,7.1 \mathrm{~Hz}$, 2H). ${ }^{17} \mathrm{O}$ NMR (68 MHz, Acetone- $\left.d_{6}\right): \delta 245$.

$\left[{ }^{17} \mathrm{O}_{2}\right]$ 2-ethoxy-2-oxoethyl benzoate $\left.\left(\boldsymbol{I}^{17} \boldsymbol{O}_{2}\right] 26\right) .{ }^{31}$ To a solution of $\left[{ }^{17} \mathbf{O}_{2}\right] 25(1.62 \mathrm{mmol})$ and $\mathrm{Cu}(\mathrm{OTf})_{2}$ $(5.9 \mathrm{mg})$ in toluene $(10 \mathrm{~mL})$ ethyl diazoacetate was added dropwise $(3.24 \mathrm{mmol})$ and the resulting mixture was warmed up to $80{ }^{\circ} \mathrm{C}$ and stirred for $12 \mathrm{~h}$. After completion, the reaction mixture was filtered and toluene was evaporated in vacuo. The final product was used without further purification. ${ }^{1} \mathrm{H}$ NMR $\left(500 \mathrm{MHz}\right.$, Acetone- $\left.d_{6}\right): \delta$ $8.09(\mathrm{~d}, J=7.7 \mathrm{~Hz}, 2 \mathrm{H}), 7.68(\mathrm{t}, J=7.5 \mathrm{~Hz}, 1 \mathrm{H}), 7.56(\mathrm{q}, J=8.0 \mathrm{~Hz}, 2 \mathrm{H}), 4.91(\mathrm{~s}, 2 \mathrm{H}), 4.23(\mathrm{q}, J=7.1 \mathrm{~Hz}, 2 \mathrm{H})$, 1.27 (tq, $J=7.2,3.6,2.6 \mathrm{~Hz}, 3 \mathrm{H}) .{ }^{17} \mathrm{O} \mathrm{NMR}\left(68 \mathrm{MHz}\right.$, Acetone- $\left.d_{6}\right): \delta 340,136$.

$\left[{ }^{17} \mathrm{O}\right]$ Benzyl alcohol $\left[{ }^{17} \mathbf{O}\right] 27$. Compound $\left[{ }^{17} \mathbf{O}_{2}\right] 25(1.60 \mathrm{mmol})$ was dissolved in THF $(20 \mathrm{~mL})$. A solution of $\mathrm{LiAlH}_{4}$ in THF $(1.48 \mathrm{~mL}, 2.5 \mathrm{M})$ was slowly added to the resulting mixture at $0{ }^{\circ} \mathrm{C}$ and the reaction was allowed to stir at room temperature until total consumption of starting material. After completion, a solution of $\mathrm{NaOH} 1 \mathrm{~N}(10 \mathrm{~mL})$ was used to quench the reaction and the aqueous layer was extracted with $\mathrm{CH}_{2} \mathrm{Cl}_{2}(3 \times 10$ $\mathrm{mL}$ ). The organic layers were dried over $\mathrm{MgSO}_{4}$, filtered and concentrated in vacuo. The final product was purified by flash column chromatography on silica gel using a hexane/ethyl acetate mixture $\left(60 / 40, R_{f} 0.59\right)$ as 
eluent, and isolated as a pale yellow oil $(149 \mathrm{mg})$ in $85 \%$ yield. ${ }^{1} \mathrm{H}$ NMR $\left(500 \mathrm{MHz}, \mathrm{CDCl}_{3}\right): \delta 7.37(\mathrm{~d}, J=4.5$ $\mathrm{Hz}, 4 \mathrm{H}), 7.32-7.28(\mathrm{~m}, 1 \mathrm{H}), 4.70(\mathrm{~d}, J=2.3 \mathrm{~Hz}, 2 \mathrm{H}), 1.67(\mathrm{~s}, 1 \mathrm{H}) .{ }^{17} \mathrm{O}$ NMR $\left(68 \mathrm{MHz}\right.$, Acetone- $\left.d_{6}\right): \delta 0$.

$\left[{ }^{17} \mathrm{O}\right]$ Benzaldehyde $\left.\left(\boldsymbol{I}^{17} \mathbf{O}\right] 28\right) .{ }^{52}$ A solution of oxalyl chloride $(2.33 \mathrm{mmol})$ in $\mathrm{CH}_{2} \mathrm{Cl}_{2}(3 \mathrm{~mL})$ was cooled to $-84{ }^{\circ} \mathrm{C}$ and dimethyl sulfoxide $(4.65 \mathrm{mmol})$ was added slowly. The resulting mixture was stirred for additional 15 minutes. $\left[{ }^{17} \mathbf{O}_{1}\right] 27(1.37 \mathrm{mmol})$ was added to the reaction and the mixture was allowed to stir for 15 minutes. Triethylamine $(6.85 \mathrm{mmol})$ was slowly added and the resulting white suspension was stirred at the indicated temperature for $2 \mathrm{~h}$. After completion, the reaction was warmed up to $0{ }^{\circ} \mathrm{C}$, quenched with $\mathrm{HCl} 3 \mathrm{~mL}$ ) and extracted with $\mathrm{CH}_{2} \mathrm{Cl}_{2}(3 \times 5 \mathrm{~mL})$. The organic layer was washed with $\mathrm{NaHCO}_{3}$ sat. $(2 \times 5 \mathrm{~mL})$ and the combined organic layers were dried over $\mathrm{MgSO}_{4}$, filtered and concentrated in vacuo at $0{ }^{\circ} \mathrm{C}$. The desired compound was isolated as a colorless oil $(95 \mathrm{mg})$ in $65 \%$ yield and used in the next step without further purification. ${ }^{1} \mathrm{H}$ NMR $\left(400 \mathrm{MHz}, \mathrm{CDCl}_{3}\right): \delta 10.06(\mathrm{~s}, 1 \mathrm{H}), 7.95-7.88(\mathrm{~m}, 2 \mathrm{H}), 7.72-7.63(\mathrm{~m}, 1 \mathrm{H}), 7.57(\mathrm{dd}, J=8.2,6.9 \mathrm{~Hz}, 2 \mathrm{H}) .{ }^{17} \mathrm{O}$ $\operatorname{NMR}\left(68 \mathrm{MHz}, \mathrm{CDCl}_{3}\right): \delta 554$.

$\left[{ }^{17} \mathrm{O}\right] 1$-Phenylprop-2-en-1-ol $\left.\left(\boldsymbol{I}^{17} \boldsymbol{O}\right] \mathbf{1 b}\right) .{ }^{53}$ To a solution of $\left[{ }^{17} \mathbf{O}_{1}\right] 28(0.89 \mathrm{mmol})$ in THF $(6 \mathrm{~mL})$ was slowly added at $0^{\circ} \mathrm{C}$ a solution of vinylmagnesium bromide in THF $(1.07 \mathrm{mmol}, 1 \mathrm{M})$. The reaction mixture was stirred at room temperature for 4 hours after which a saturated $\mathrm{NH}_{4} \mathrm{Cl}$ solution $(3 \mathrm{~mL})$ was added. The aqueous layer was extracted with $\mathrm{Et}_{2} \mathrm{O}(4 \times 6 \mathrm{~mL})$. The organic layers were dried over $\mathrm{MgSO}_{4}$, filtered and concentrated in vacuo. The residue was purified by flash column chromatography on silica gel using a hexane/ethyl acetate mixture $\left(70: 30, R_{f} 0.60\right)$ to afford the desired product as a yellow oil $(64 \mathrm{mg})$ in $54 \%$ yield. ${ }^{1} \mathrm{H} \mathrm{NMR}(400 \mathrm{MHz}$, $\left.\mathrm{CDCl}_{3}\right): \delta 7.42-7.34(\mathrm{~m}, 4 \mathrm{H}), 7.29(\mathrm{td}, J=5.7,2.5 \mathrm{~Hz}, 1 \mathrm{H}), 6.06(\mathrm{ddd}, J=16.7,10.3,6.0 \mathrm{~Hz}, 1 \mathrm{H}), 5.35(\mathrm{dd}, J$ $=16.7,1.6 \mathrm{~Hz}, 1 \mathrm{H}), 5.24-5.18(\mathrm{~m}, 2 \mathrm{H}) .{ }^{17} \mathrm{O} \mathrm{NMR}\left(68 \mathrm{MHz}, \mathrm{CDCl}_{3}\right): \delta 31$.

$\left[{ }^{17} O_{1}\right] 1$-phenylallyl tosylcarbamate $\left(\left[{ }^{17} \mathbf{O}_{1}\right] 13 b\right) .{ }^{5 c}$ To a solution of 1-phenylprop-2-en-1-ol $\left[{ }^{17} \mathbf{O}_{1}\right] \mathbf{1 b}$ $(0.073 \mathrm{mmol})$ in toluene $(0.2 \mathrm{M})$ under argon atmosphere, $p$-toluenesulfonylisocyanate $(0.088 \mathrm{mmol})$ was added dropwise and the mixture was stirred at room temperature for 5 minutes. The resulting mixture was concentrated in vacuo and purified using a hexane/ethyl acetate mixture $\left(80 / 20, R_{f} 0.31\right)$ as eluent. The product was isolated as a colorless oil $(21 \mathrm{mg})$ in $90 \%$ yield. ${ }^{1} \mathrm{H}$ NMR $\left(400 \mathrm{MHz}, \mathrm{CDCl}_{3}\right) \delta 7.88(\mathrm{~d}, J=8.3 \mathrm{~Hz}, 2 \mathrm{H}), 7.55-7.53$ (br s, $1 \mathrm{H}), 7.34-7.26(\mathrm{~m}, 5 \mathrm{H}), 7.21(\mathrm{dd}, J=6.8,3.0 \mathrm{~Hz}, 2 \mathrm{H}), 6.11(\mathrm{dd}, J=6.0,1.5 \mathrm{~Hz}, 1 \mathrm{H}), 5.92(\mathrm{ddd}, J=16.7,10.5$, $5.9 \mathrm{~Hz}, 1 \mathrm{H}), 5.27-5.23(\mathrm{~m}, 2 \mathrm{H}), 2.43(\mathrm{~s}, 3 \mathrm{H}) .{ }^{17} \mathrm{O} \mathrm{NMR}\left(68 \mathrm{MHz}, \mathrm{CDCl}_{3}\right): \delta 150,129$.

$\left[{ }^{17} O_{I}\right](E)-3-\left(\right.$ phenyl)allyl tosylcarbamate $\left.\left(I^{17} \boldsymbol{O}_{1}\right] \mathbf{1 4 b}\right) .{ }^{50}$ Prepared from $\left[{ }^{17} \mathbf{O}_{\mathbf{1}}\right] \mathbf{1 b}\left(90{ }^{\circ} \mathrm{C}, 4 \mathrm{~h}\right)$ and purified using a hexane/ethyl acetate mixture $\left(60 / 40, R_{f} 0.39\right)$ as eluent. The product was isolated as a white solid $(21 \mathrm{mg})$ in $86 \%$ yield. ${ }^{1} \mathrm{H}$ NMR (400 MHz, $\left.\mathrm{CDCl}_{3}\right) \delta 7.97-7.90(\mathrm{~m}, 1.5 \mathrm{H}), 7.82(\mathrm{~m}, 0.5 \mathrm{H}), 7.37-7.25(\mathrm{~m}, 7 \mathrm{H})$, $6.58(\mathrm{~d}, J=15.8 \mathrm{~Hz}, 1 \mathrm{H}), 6.14(\mathrm{dt}, J=15.9,6.6 \mathrm{~Hz}, 1 \mathrm{H}), 4.72(\mathrm{dd}, J=6.6,1.3 \mathrm{~Hz}, 2 \mathrm{H}), 2.43(\mathrm{~s}, 0.75 \mathrm{H}), 2.42(\mathrm{~s}$, 2.25H). ${ }^{17} \mathrm{O}$ NMR (68 MHz, Chloroform- $d$ ) $\delta$ 264, 125. HRMS (ESI): $\mathrm{m} / z$ calcd. for $\left[\boldsymbol{I}^{\mathbf{1 7}} \boldsymbol{O}_{\boldsymbol{l}} \boldsymbol{l} \boldsymbol{1 4 \boldsymbol { b }}\right.$ : calculated for $\mathrm{C}_{17} \mathrm{H}_{17} \mathrm{NO}_{4} \mathrm{SNa}[\mathrm{M}+\mathrm{Na}]^{+}$354.0763; found: $354.0763(59 \%)$; calculated for $\mathrm{C}_{17} \mathrm{H}_{17} \mathrm{NO}_{3}{ }^{17} \mathrm{OSNa}[(\mathrm{M}+1)+\mathrm{Na}]^{+}$ 355.0805; found: 355.0799 (11\%); calculated for $\mathrm{C}_{17} \mathrm{H}_{17} \mathrm{NO}_{3}{ }^{18} \mathrm{OSNa}[(\mathrm{M}+2)+\mathrm{Na}]^{+}$356.0806; found: 356.0799 $(30 \%)$.

\section{Procedure for NMR monitoring of the $\left[{ }^{17} \mathrm{O}_{1}\right] 13 \mathrm{~b} \rightarrow\left[{ }^{17} \mathrm{O}_{1}\right] 14 \mathrm{~b}$ transformation}

To a solution of 1-phenylprop-2-en-1-ol $\left[{ }^{17} \mathbf{O}_{1}\right] \mathbf{1} \mathbf{b}(0.373 \mathrm{mmol})$ in toluene $(0.2 \mathrm{M})$ under argon atmosphere, $p$-toluenesulfonylisocyanate $(0.447 \mathrm{mmol})$ was added dropwise. The reaction was heated to $90{ }^{\circ} \mathrm{C}$, 
and $200 \mu \mathrm{L}$ were taken from the reaction medium every 20 minutes. The solvent was removed and the resulting colorless oil was dissolved in $\mathrm{CDCl}_{3}$ to perform ${ }^{17} \mathrm{O} \mathrm{NMR}$ experiments at room temperature.

Computational Methods. All of the calculations reported in this work were carried out with the GAUSSIAN 09 suite of programs ${ }^{54}$ and using the hybrid DFT functional B3LYP 55 with the D3 dispersion empirical correction ${ }^{56}$ and the $6-311++\mathrm{G}(\mathrm{d}, \mathrm{p})$ basis set. ${ }^{57}$ The most stable conformations of reactants and products were previously determined by MM Monte Carlo simulations using the OPLS force field ${ }^{58}$ as implemented in the MacroModel program Implemented in the Shrödinger Maestro suite $)^{59}$ and then subjected to DFT optimizations. All the stationary points were characterized by harmonic analysis. Reactants and products showed positive definite Hessians. Transition structures (TSs) showed one and only one imaginary frequency associated with nuclear motion along the chemical transformation under study. Free energies at $363.15 \mathrm{~K}$ were calculated by including the corresponding thermal corrections to Gibbs free energies (TCGE). Solvent effects were considered by means of the PCM method. ${ }^{60}$ The solvent introduced in the calculations was toluene. Natural bonding analysis calculations were performed using the NBO program ${ }^{61}$ as implemented in Gaussian 09.

\section{ASSOCIATED CONTENT}

Supporting Information. This material is available free of charge via the Internet at http://pubs.acs.org.

$>$ Copies of ${ }^{1} \mathrm{H},{ }^{13} \mathrm{C}$ NMR spectra and chiral HPLC chromatography of all new compounds. Copies of ${ }^{17} \mathrm{O}$ NMR of 25, 26, 27, 28, 1b, 13b, 14b. First order linear plot obtained for compounds 14a-c. Cartesian coordinates, number of imaginary frequencies (NIMAG), and energy data of stationary points gathered in Figure 5, 7, 8, 9 and 10.

Crystal data, CCDC 1824810 for $\mathbf{1 4 e}(\mathrm{CIF})$

\section{AUTHOR INFORMATION}

\section{Corresponding Author}

*E-mail: francois.carreaux@univ-rennes1.fr.; fp.cossio@ehu.eus.

\section{Notes}

The authors declare no competing financial interest.

\section{ACKNOWLEDGEMENTS}

This work was supported by the University of Rennes 1, the Centre National de la Recherche Scientifique (CNRS), the Ministerio de Economía y Competitividad (MINECO) of Spain and FEDER (Projects CTQ2016-80375-P and CTQ2014-51912-REDC) and the Gobierno 
Vasco/Eusko Jaurlaritza (GV/EJ, grant IT-324-07). One of us (S.H.) thanks La region Bretagne and VillaPharma Research for a research fellowship. M.A. thanks the Eusko Jaurlaritza-Gobierno Vasco for her PhD fellowship. I. R. and F. P. C. thank the SGI/IZOSGIker UPV/EHU and the DIPC for generous allocation of computational and analytical resources.

\section{REFERENCES}

(1) Some selected reviews on [3,3]-sigmatropic rearrangements, see: (a) Nubbemeyer, U. Recent Advances in Asymmetric [3,3]-Sigmatropic Rearrangements. Synthesis 2003, 961-1008. (b) Ilardi, E. A.; Stivala, C. E.; Zakarian, A. [3,3]-Sigmatropic Rearrangements: Recent Applications in the Total Synthesis of Natural Products. Chem. Soc. Rev. 2009, 38, 3133-3148. (c) Jones, A. C.; May, J. A.; Sarpong, R.; Stoltz, B. M. Toward a Symphony of Reactivity: Cascades Involving Catalysis and Sigmatropic Rearrangements. Angew. Chem. Int. Ed. 2014, 53, 2556-2591.

(2) (a) Overman, L. E. Thermal and Mercuric Ion Catalyzed [3,3]-Sigmatropic Rearrangement of Allylic Trichloroacetimidates. 1,3 Transposition of Alcohol and Amine Functions. J.Am. Chem. Soc. 1974, 96, 597599. (b) Overman, L. E.; Carpenter, N. E. The Allyl Trihaloacetimidate Rearrangement. In Organic reactions; Overman, L. E., Ed.; Wilev: New York, 2005; vol. 66, p. 1-107.

(3) For recent reviews, see: (a) Majumdar, K. C.; Bhattacharyva, T.; Chattopadhyay, B.; Sinha, B. Recent Advances in the Aza-Claisen Rearrangement. Synthesis 2009, 2117-2142. (b) Arnold, J. S.; Zhang, Q.; Nguyen, H. M. Transition-Metal-Catalyzed Allylic Substitutions of Trichloroacetimidates. Eur. J. Org. Chem. 2014, 4925-4948. (c) Fernandes, R. A.; Kattanguru, P.; Gholap, S. P.; Chaudhari, D. A. Recent Advances in Overman Rearrangement: Synthesis of Natural Products and Valuable Compounds. Org. Biomol. Chem. 2017, 15, 2672 2710.

(4) For the pioneer work, see: (a) Synerholm, M. E.; Gilman, N. W.; Morgan, J. W.; Hill, R. K. A New Thermal Rearrangement of Allylic Phenylurethans. J. Org. Chem. 1968, 33, 1111-1116. (b) Wang, C.-L. J.; Calabrese, J. C. Decarboxylative Cyclization of Allylic Cyclic Carbamates: Applications to the Total Synthesis of (-)Codonopsine. J. Org. Chem. 1991, 56, 4341-4343.

(5) For some recent representative examples, see: (a) Lei, A.; Lu, X. A Facile Highly Regio- and Stereoselective Preparation of N-Tosyl Allylic Amines from Allyl Alcohols and Tosyl Isocyanate via Palladium(II)-Catalyzed Aminopalladation- $\beta$-Heteroatom Elimination. Org. Lett. 2000, 2, 2357-2360. (b) Singh, O. V.; Han, H. Iridium(I)-Catalyzed Regio- and Enantioselective Decarboxylative Allylic Amidation of Substituted Allyl Benzyl Imidodicarbonates. J.Am. Chem. Soc. 2007, 129, 774- 775. (c) Xing, D.; Yang, D. Gold(I)-Catalyzed Highly Regio-and Stereoselective Decarboxylative Amination of Allylic N-Tosylcarbamates via Base-Induced Aza-Claisen Rearrangement in Water. Org. Lett. 2010, 12, 1068-1071. (d) Bauer, J. M.; Frey, W.; Peters, R. Asymmetric Cascade Reaction to Allylic Sulfonamides from Allylic Alcohols by Palladium(II)/Base-Catalyzed Rearrangement of Allylic Carbamates. Angew. Chem. Int. Ed. 2014, 53, 7634-7638. (e) Bauer, J. M.; Frey, W.; Peters, R. Dual Palladium(II)/Tertiary Amine Catalysis for Asymmetric Regioselective Rearrangements of Allylic Carbamates. Chem. Eur. J. 2016, 22, 5767-5777. (f) Kondoh, A.; Kamata, Y.; Terada, M. Synthesis of 
Enantioenriched $\gamma$-Amino- $\alpha, \beta$-unsaturated Esters Utilizing Palladium-Catalyzed Rearrangement of Allylic Carbamates for Direct Application to Formal [3+2] Cycloaddition. Org. Lett. 2017, 19, 1682-1685.

(6) Christophersen, C.; Holm, A. Alkyl Cyanates. XIV. Isomerization of Allylic Cyanates and Allylic Thionoderivatives. Acta Chem. Scand. 1970, 24, 1512-1526.

(7) (a) Ichikawa, I. Evolution, Development and Personal Experience in Studies of The Allyl Cyanate-toIsocyanate Rearrangement. Synlett 2007, 2927-2936. (b) Nocquet, P.-A.; Henrion, S.; Macé, A.; Carboni, B.; Villalgordo, J. M.; Carreaux, F. The Allyl Cyanate/Isocyanate Rearrangement: An Efficient Tool for the Stereocontrolled Formation of Allylic C-N Bonds. Eur. J. Org. Chem. 2017, 1295-1307.

(8) For some examples, see: (a) Ichikawa, Y.; Yamazaki, M.; Isobe, M. Novel, Regioselective Allylamine Construction; First Synthesis of Geranyllinaloisocyanide, a Diterpene from the Marine Sponge, Halichondria Sp. J. Chem. Soc. Perkin Trans. 1, 1993, 2429-2432. (b) Perreault, S.; Rovis, T. Enantiselective Synthesis of the Tricyclic Core of FR901483 Featuring a Rh-Catalyzed [2+2+2] Cycloaddition. Sunthesis, 2013, 45, 719-728. (c) Ramb, D. C.; Kost, L.; Haufe, G. [3,3]-Sigmatropic Rearrangements of Fluorinated Allyl (Thio)cyanates-A Tool for the Synthesis of Fluorinated (Thio)ureas. Chimia 2014, 68, 436-441.

(9) (a) Touchet, S.; Macé, A.; Roisnel, T.; Carreaux, F.; Bouillon, A.; Carboni, B. [3,3]-Sigmatropic Rearrangement of Boronated Allylcyanates: A New Route to $\alpha$-Aminoboronate Derivatives and Trisubstituted Tetrahydrofurans. Org. Lett. 2013, 15, 2712-2715. (b) Touchet, S.; Andres, P.; Cossio, F. P.; Dorcet, V.; Carreaux, F.; Carboni, B. [3,3]-Sigmatropic Rearrangement/Allylboration/Cyclization Sequence: Enantioenriched Seven-Membered-Ring Carbamates and Ring Contraction to Pyrrolidines. Angew. Chem. Int. Ed. 2016, 55, 1025-1029. (c) Henrion, S.; Carboni, B.; Cossio, F. P.; Roisnel, T.; Villalgordo, J. M.; Carreaux, F. Stereospecific Synthesis of $\alpha$-Amino Allylsilane Derivatives through a [3,3]-Allyl Cyanate Rearrangement. Mild Formation of Functionalized Disiloxanes. J. Org. Chem. 2016, 81, 4633-4644. (d) Henrion, S.; Macé, A.; Vallejos, M. M.; Carboni, B.; Villalgordo, J. M.; Carreaux, F. Asymmetric Synthesis of trans-4,5-disubstituted $\gamma$ butyrolactones involving a key allylboration step. First access to (-)-nicotlactone B and (-)-galbacin. Org. Biomol. Chem. 2018, 16, 1672-1678.

(10) For the first observation of this rearrangement in the gas phase, see: (a) Lewis, E. S.; Hill, J. T.; Newman, E. R. Rearrangement of Esters in the Gas Phase. II. Substituent Effects on the Rate of Isomerization of Allyllic Esters. J:Am. Chem. Soc. 1968, 90, 662-668. (b) Lewis, E. S.; Hill, J. T. Rearrangement of Esters in the Gas Phase. IV. Fate of an Oxygen Tracer in the Rearrangement of Crotyl Trifluoroacetate. J. Am. Chem. Soc. 1969, 91, 7458-7462. (c) Leavell, K. H.; Lewis, E. S. Gas Phase Thermolysis of Allylic Formates. Kinetic and Isotype Effects. Tetrahedron 1972, 28, 1167-1171.

(11) For a recent computational study of the sigmatropic rearrangement of allyl esters, see: (a) Birney, D. M.; $\mathrm{Xu}, \mathrm{X}$; Ham, S. [1,3], [3,3], and [3,5] Sigmatropic Rearrangements of Esters Are Pseudopericyclic. Angew. Chem. Int. Ed. 1999, 38, 189-193. (b) Sharma, S.; Rajale, T.; Cordes, D. B.; Hung-Low, F.; Birney, D. M. Experimental and Computational Studies on the [3,3]- and [3,5]-Sigmatropic Rearrangements of Acetoxycyclohexadienones: A non-ionic Mechanism for Acyl Migration. J. Am. Chem. Soc. 2013, 135, 1443814447.

(12) Nomenclature has been suggested by the following paper: Vögtle, F.; Goldschmitt, E. Die Diaza-CopeUmlagerung. Chem. Ber. 1976, 109, 1-40. 
(13) A similar rearrangement was observed as side-reaction, see ref. 5c.

(14) (a) Overman, L. E. Mercury (II)- and Palladium (II)- Catalyzed [3,3]-Sigmatropic Rearrangements. Angew. Chem. Int. Ed. 1984, 23, 579-589 and references cited therein. (b) Garner, P.; Park, J. M. Asymmetric Synthesis of 5-O-Carbamoylpolyoxamic Acid from D-Serine. J. Org. Chem. 1988, 53, 2979-2984. (c) Crich, D.; Natarajan, S. Synthesis of Highly Functionalized AB Taxane Ring System: Formation of the Eight-Membered Ring by an Efficient 8-exo-tet Alkylation of an $\alpha$-Sulfonyl Anion. J. Chem. Soc., Chem. Commun. 1995, 85-86. (d) Christie, S. D. R.; Warrington, A. D.; Lunniss, C. J. Complementary Reactions of Allylic Carbamates Using Palladium (II): Formation of Oxazolidinones or Allylic Amides from a Common Precursor. Synthesis, 2009, 148-154. (e) Percy, J. M.; McCarter, A. W.; Sewel, A. L.; Sloan, N.; Kennedy, A. R.; Hirst, D. J. Developing the Saegusa-Ito Cyclisation for the Synthesis of Difluorinated Cyclohexenones. Chem. Eur. J. 2015, 21, 1911919127.

(15) For some recent examples of allyl carbamates, see: (a) Donohoe, T. J.; Johnson, P. D.; Helliwell, M.; Keenan, M. The Regioselective Aminohydroxylation of Allylic Carbamates. Chem. Commun. 2001, 2078-2079. (b) Alexanian, E. J.; Lee, C.; Sorensen, E. J. Palladium-Catalyzed Ring-Forming Aminoacetoxylation of Alkenes. J. Am. Chem. Soc. 2005, 127, 7690-7691. (c) Deng, Q.-H.; Wang, J.-C.; Xu, Z.-J.; Zhou, C.-Y.; Che, C.-M. Metal-Free Intramolecular Aziridination of Allylic Carbamates Mediated by Hypervalent Iodine Compounds. Synthesis 2011, 2959-2967. (d) Unsworth, W. P.; Lamont, S. G.; Robertson, J. Substrate Scope and Stereocontrol in the Rh(II)-Catalysed Oxyamination of Allylic Carbamates. Tetrahedron, 2014, 70, 7388-7394.

(e) Pan, H.; Huang, H.; Liu, W.; Tian, H.; Shi, Y. Phosphine Oxide-Sc(Otf) ${ }_{3}$ Catalyzed Highly Regio- and Enantioselective Bromoaminocyclization of $(E)$-Cinnamyl Tosylcarbamates. An Approach to a Class of Synthetically Versatile Functionalized Molecules. Org. Lett. 2016, 18, 896-899.

(16) Ghosh, A. K.; Brindisi, M. Organic Carbamates in Drug Design and Medicinal Chemistry. J. Med. Chem. 2015, 58, 2895-2940.

(17) This kind of allyl carbamates are generally synthesized from the reaction of primary allyl alcohols with isocyanates.

(18) $\mathrm{CDCl}_{3}$ can be efficiently replaced by $\mathrm{CH}_{2} \mathrm{Cl}_{2}$.

(19) The (E)-3-(4-methoxyphenyl)prop-2-en-1-ol was prepared from anisaldehyde according to the following publication: Bouziane, A.; Carboni, B.; Bruneau, C.; Carreaux, F.; Renaud, J.-L. Pentamethylcyclopentadienyl Ruthenium: an Efficient Catalyst for the Redox Isomerization of Functionalized Allylic Alcohols into Carbonyl Compounds. Tetrahedron 2008, 64, 11745-11750.

(20) For some recent synthetic applications of dienyl carbamates, see: (a) Donohoe, T. J.; Bataille, C. J. R.; Gattrell, W.; Kloesges, J.; Rossignol, E. Tethered Aminohydroxylation: Dramatic Improvements to the Process. Org. Lett. 2007, 9, 1725-1728. (b) Guasch, J.; Diaz, Y.; Matheu, M. I.; Castillon, S. Rhodium-Catalyzed Regioand Stereoselective Oxyamination of Dienes via Tandem Aziridination/Ring-Opening of Dienyl Carbamates. Chem. Commun. 2014, 50, 7344-7347. (c) Guasch, J.; Giménez-Nueno, I.; Funez-Ardoiz, I.; Bernús, M.; Matheu, M. I.; Maseras, F.; Castillón, S.; Díaz, Y. Enantioselective Synthesis of Aminodiols by Sequential Rhodium-Catalysed Oxyamination/Kinetic Resolution: Expanding the Substrate Scope of Amidine-Based Catalysis. Chem. Eur. J. 2018, 24, 4635-4642 and ref. 10d. 
(21) Some examples have been reported in the literature, see: reference 6a and Chwastek, M.; Pieczykolan, M.; Stecko, S. The Synthesis of 5-Amino-dihydrobenzo[b]oxepines and 5-Amino-dihydrobenzo[b]azepines via Ichikawa Rearrangement and Ring-Closing Metathesis. J. Org. Chem. 2016, 81, 9046-9071.

(22) Spino, C.; Joly, M.-A.; Godbout, C.; Arbour, M. Ti-Catalyzed Reactions of Hindered Isocyanates with Alcohols. J. Org. Chem. 2005, 70, 6118-6121.

(23) No formation of $\mathbf{1 1}$ and $\mathbf{1 2}$ at room temperature in the absence of $\mathrm{Et}_{3} \mathrm{~N}$ and DMAP. Alkyl carbamate 12 can also be prepared from 1a and isopropyl isocyanate using $\mathrm{CuCl}$ as catalyst, see: Duggan, M. E.; Imagire, J. S. Copper(I) Chloride Catalyzed Addition of Alcohols to Alkyl Isocyanates. A Mild and Expedient Method for Alkyl Carbamate Formation. Synthesis 1989, 131-132.

(24) To avoid a slight formation of rearranged products during the purification, a prior deactivation of silica gel with triethylamine has been necessary.

(25) Akai, S.; Hanada, R.; Fujiwara, N.; Kita, Y.; Egi, M. One-Pot Synthesis of Optically Active Allyl Esters via Lipase-Vanadium Combo Catalysis. Org. Lett. 2010, 12, 4900-4903.

(26) From $(S)-20$, the carbamoylation/rearrangement sequence is complete after $1 \mathrm{~h}$ at room temperature using tosyl isocyanate. However, the enantiomeric excess of this rearranged product could not be determined due to its instability during HPLC analysis.

(27) (a) Sharma, S.; Rajale, T.; Unruh, D. K.; Birney, D. M. Competitive Pseudopericyclic [3,3]- and [3,5]Sigmatropic Rearrangements of Trichloroacetimidates. J. Org. Chem. 2015, 80, 11734-11743.

(28) Kreiman, H. W.; Batali, M. E.; Jamieson, C. S.; Lyon, M. A.; Duncan, J. A. CASSCF Calculations Reveal Competitive Chair (Pericyclic) and Boat (Pseudopericyclic) Transition States for the [3,3] Sigmatropic Rearrangement of Allyl Esters. J. Org. Chem. 2018, 83, 1717-1726.

(29) Woodward, R. B.; Hoffmann, R. The Conservation of Orbital Symmetry. Angew. Chem. Int. Ed. 1969, 8, 781-853.

(30) (a) Retamosa, M. de G.; Ruiz-Olalla, A.; Bello, T.; de Cózar, A.; Cossío, F. P. A Three-Component Enantioselective Cyclization Reaction Catalyzed by an Unnatural Amino Acid Derivative. Angew. Chem. Int. Ed. 2018, 57, 668-672. (b) Haiss, P.; Zeller, K.-D. Loss of Isotope Labeling in the Conversion of $\left[{ }^{18} \mathrm{O}_{2}\right]$ Benzoic Acid into $\left[{ }^{18} \mathrm{O}\right]$ benzoyl Chloride with Oxalyl Chloride. Angew. Chem. Int. Ed. 2003, 42, 303-305.

(31) Chen, J.; Shao, Y.; Liang, M.; Meihua M.; Wan, X. In Situ Generation of Nitrilium from Nitrile Ylide and the Subsequent Mumm Rearrangement: Copper-Catalyzed Synthesis of Unsymmetrical Diacylglycine Esters. Org. Biomol. Chem. 2016, 14, 10723-10732.

(32) Nummert, V.; Piirsalu, M.; Toom, L.; Kesvatera, T.; Leito, I.; Koppel, I. Effect of Charged and Ortho Substituents on ${ }^{17} \mathrm{O}$ NMR Chemical Shifts of Substituted Phenyl Tosylates in DMSO. J. Phys. Org. Chem. 2018; e3870-3883.

(33) Bickelhaupt, F. M.; Houk, K. N. Analyzing Reaction Rates with the Distortion/Interaction-Activation Strain Model. Angew. Chem. Int. Ed. 2017, 56, 10070-10086.

(34) Hansch, C.; Leo, A.; Taft, R. W. A Survey of Hammett Substituent Constants and Resonance and Field Parameters. Chem. Rev. 1991, 91, 165-195.

(35) (a) Hammond, G. S. A Correlation of Reaction Rates. J. Am. Chem. Soc. 1955, 77, 334-338. (b) Marcus, R. A. Chemical and Electrochemical Electron-Transfer Theory. Annu. Rev. Phvs. Chem. 1964, 15, $155-196$. 
(36) Hayden, A. E.; Houk, K. N. Transition State Distortion Energies Correlate with Activation Energies of 1,4Dihydrogenations and Diels-Alder Cycloadditions of Aromatic Molecules. J.Am. Chem. Soc. 2009, 131, 40844089.

(37) Ess, D. H.; Houk, K. N. Distortion/Interaction Energy Control of 1,3-Dipolar Cycloaddition Reactivity. $J$. Am. Chem.Soc. 2007, 129, 10646-10647.

(38) Deng, Z.; Wei, J.; Liao, L.; Huang, H.; Zhao, X. Organoselenium-Catalyzed, Hydroxy-Controlled Regioand Stereoselective Amination of Terminal Alkenes: Efficient Synthesis of 3-Amino Allylic Alcohols. Org. Lett. 2015, 17, 1834-1837.

(39) Bouziane, A.; Helou, M.; Carboni, B.; Carreaux, F.; Demerseman, B.; Bruneau, C.; Renaud, J. L. Ruthenium-Catalyzed Synthesis of Allylic Alcohols: Boronic Acid as a Hydroxide Source. Chem. Eur. J. 2008, $14,5630-5637$.

(40) Slagbrand, T.; Lundberg, H.; Adolfsson, H. Ruthenium-Catalyzed Tandem-Isomerization/Asymmetric Transfer Hydrogenation of Allylic Alcohols. Chem. Eur. J. 2014, 20, 16102-16106.

(41) Lehmann, J., Lloyd-Jones, G. C. Regiocontrol and Stereoselectivity in Tungsten-Bipyridine Catalysed Allylic Alkylation. Tetrahedron, 1995, 51, 8863-8874.

(42) Njiojob, C. N.; Rhinehart, J. L.; Bozell, J. J.; Long, B. K. Synthesis of Enantiomerically Pure Lignin Dimer Models for Catalytic Selectivity Studies. J. Org. Chem. 2015, 80, 1771-1780.

(43) Morril, C.; Grubbs, R. H. Highly Selective 1,3-Isomerization of Allylic Alcohols via Ruthenium Oxo Catalysis. J. Am. Chem. Soc. 2005, 127, 2842-2843.

(44) Hui, L.; Yan, L.; Zhong-Liu, W. Highly Diastereo- and Enantio-selective Epoxidation of Secondary Allylic Alcohols Catalyzed by Styrene Monooxygenase. Chem. Commun. 2011, 47, 2610-2612.

(45) Swain, N. A.; Brown, R. C. D.; Bruton, G. A. Versatile Stereoselective Synthesis of endo,exoFurofuranones: Application to the Enantioselective Synthesis of Furofuran Lignans. J. Org. Chem. 2004, 69, $122-129$.

(46) Lafrance, M.; Roggen, M.; Carreira, E. M. Direct, Enantioselective Iridium-Catalyzed Allylic Amination of Racemic Allylic Alcohols. Angew. Chem. Int. Ed. 2012, 51, 3470-3473.

(47) Lindstedt, E.; Ghosh, R.; Olofsson, E. Metal-Free Synthesis of Aryl Ethers in Water. Org. Lett. 2013, 15, 6070-6073.

(48) Han, S. B.; Krische, M. J. Reductive Aldol Coupling of Divinyl Ketones via Rhodium-Catalyzed Hydrogenation: syn-Diastereoselective Construction of $\beta$-Hydroxyenones. Org. Lett. 2006, 8, 5657-5660.

(49) Srinivas, H. D.; Zhou, Q., Watson, M. P. Enantiospecific, Nickel-Catalyzed Cross-Couplings of Allylic Pivalates and Arylboroxines. Org. Lett., 2014, 16, 3596-3599.

(50) Chow, S. Y.; Stevens, M. Y.; Odell, L. R. Sulfonyl Azides as Precursors in Ligand-Free PalladiumCatalyzed Synthesis of Sulfonyl Carbamates and Sulfonyl Ureas and Synthesis of Sulfonamides. J. Org. Chem. 2016, 81, 2681-2691.

(51) Cooper, T. S.; Laurent, P.; Moody, C. J.; Takle, A. K. Asymmetric Synthesis of N-Protected Amino Acids by the Addition of Organolithium Carboxyl Synthons to ROPHy/SOPHy-Derived Aldoximes and Ketoximes. Org. Biomol. Chem. 2004, 2, 265-276. 
(52) Neuvonen, A. J.; Földes, T.; Madarász, Á.; Pápai, I.; Pihko, P. M. Organocatalysts Fold To Generate an Active Site Pocket for the Mannich Reaction. ACS Catal. 2017, 7, 3284-3294.

(53) Hanessian, S.; Focken, T.; Oza, R. Lewis-Acid Catalyzed Formation of Dihydropyrans. Tetrahedron 2011, $67,9870-9884$.

(54) Gaussian 09, Revision D.01: Frisch, M. J.; Trucks, G. W.; Schlegel, H. B.; Scuseria, G. E.; Robb, M. A.; Cheeseman, J. R.; Scalmani, G.; Barone, V.; Mennucci, B.; Petersson, G. A.; Nakatsuji, H.; Caricato, M.; Li, X.; Hratchian, H. P.; Izmaylov, A. F.; Bloino, J.; Zheng, G.; Sonnenberg, J. L.; Hada, M.; Ehara, M.; Toyota, K.; Fukuda, R.; Hasegawa, J.; Ishida, M.; Nakajima, T.; Honda, Y.; Kitao, O.; Nakai, H.; Vreven, T.; Montgomery, J. A., Jr.; Peralta, J. E.; Ogliaro, F.; Bearpark, M.; Heyd, J. J.; Brothers, E.; Kudin, K. N.; Staroverov, V. N.; Kobayashi, R.; Normand, J.; Raghavachari, K.; Rendell, A.; Burant, J. C.; Iyengar, S. S.; Tomasi, J.; Cossi, M.; Rega, N.; Millam, J. M.; Klene, M.; Knox, J. E.; Cross, J. B.; Bakken, V.; Adamo, C.; Jaramillo, J.; Gomperts, R.; Stratmann, R. E.; Yazyev, O.; Austin, A. J.; Cammi, R.; Pomelli, C.; Ochterski, J. W.; Martin, R. L.; Morokuma, K.; Zakrzewski, V. G.; Voth, G. A.; Salvador, P.; Dannenberg, J. J.; Dapprich, S.; Daniels, A. D.; Farkas, Ö.; Foresman, J. B.; Ortiz, J. V.; Cioslowski, J.; Fox, D. J. Gaussian, Inc., Wallingford, CT, 2009.

(55) (a) Becke, A. D. Density-Functional Thermochemistry. III. The Role of Exact Exchange. J. Chem. Phys. 1993, 98, 5648-5652. (b) Lee, C.; Yang, W.; Parr, R. G. Development of the Colle-Salvetti Correlation-Energy Formula into a Functional of the Electron Density. Phys. Rev. B 1988, 37, 785-789.

(56) Grimme, S.; Antony, J.; Ehrlich, S.; Krieg, S. A Consistent and Accurate ab Initio Parametrization of Density Functional Dispersion Correction (DFT-D) for the 94 Elements H-Pu. J. Chem. Phys. 2010, 132, 154104-154104.

(57) (a) Wiberg, K. Basis Set Effects on Calculated Geometries: 6-311++G** vs. aug-cc-pVDZ. J. Comp- Chem. 2004, 25, 1342-1346. (b) Hehre, W. J.; Random, L.; Schleyer, P. V. R.; Pople, J. A. Ab Initio Molecular Orbital Theory; Wiley: New York, 1986.

(58) (a) Jorgensen, W.L.; Tirado-Rives, J., The OPLS [Optimized Potentials for Liquid Simulations] Potential Functions for Proteins, Energy Minimizations for Crystals of Cyclic Peptides and Crambin. J. Am. Chem. Soc. 1988, 110, 1657-1666. (b) Harder, E.; Damm, W.; Maple, J.; Wu, C.; Reboul, M.; Xiang, J.Y.; Wang, L.; Lupyan, D.; Dahlgren, M.K.; Knight, J.L.; Kaus, J.W.; Cerutti, D.S.; Krilov, G.; Jorgensen, W.L.; Abel, R.; Friesner, R.A. OPLS3: A Force Field Providing Broad Coverage of Drug-like Small Molecules and Proteins. J. Chem. Theorv Comput. 2016, 12, 281-296.

(59) MacroModel, Schrödinger, LLC, New York, NY, 2018.

(60) (a) Cammi, R.; Mennucci, B.; Tomasi, J. First Evaluation of Geometries and Properties of Excited Molecules in Solution: A Tamm-Doncoff Model with Application to 4-Dimethylaminobenzonitrile. J. Phys. Chem. A 2000, 104, 5631-5637. (b) Tomasi, J.; Mennucci, B.; Cammi, R. Quantum Mechanical Continuum Solvatation Models. Chem. Rev. 2005, 105, 2999-3094.

(61) (a) Foster, J. P.; Weinhold, F. Natural Hybrid Orbitals. J. Am. Chem. Soc. 1980, 102, 7211-7218. (b) Reed, A. E.; Weinstock, R. B.; Weinhold, F. Natural Population Analysis. J. Chem. Phvs. 1985, 83, 735-746. (c) Reed, A. E.; Weinhold, F. Natural Localized Molecular Orbitals. J. Chem. Phvs. 1985, 83, 1736-1740. (d) Reed, A. E.; Curtiss, L. A.; Weinhold, F. Intermolecular Interactions from a Natural Bond Orbital, Donor-Acceptor Viewpoint. Chem. Rev. 1988, 88, 899-926. 